\title{
القيم وأهميتها في المناهج الدراسية
}

\author{
أ.م .د بثائر مولود توفيق \\ جامعة بغداد
}

مركز البحوث التربوية والنفسية بغاد

\section{Basharmawloud@yahoo.com}

(مُلَخَّصُ الَبَحث)

هـدفت البحـث الحاليـة فـي التعرّف على (القـيم وأهميتهـا فـي المنــاهج الدراسـية)،

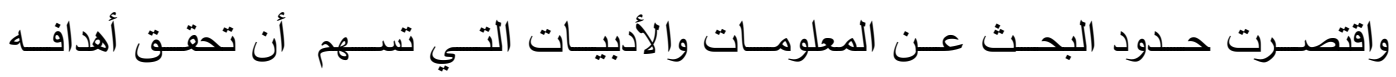

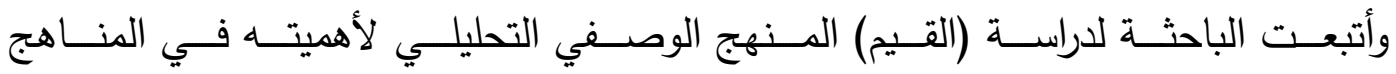

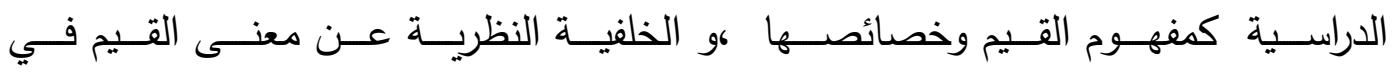

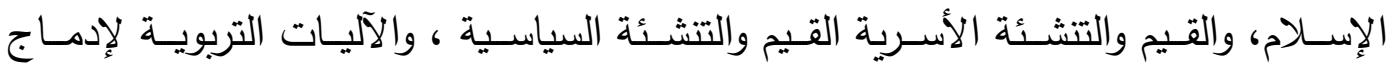
القيم في المناهج الدراسية ، وقد توصل البحث الى بعض الإسته الاستتناجات مثل :

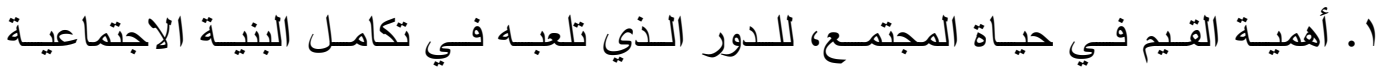

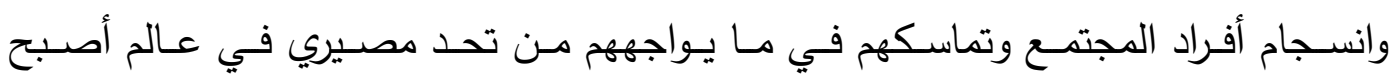
فيه لموقف المجتمع الموحد أهمية كبيرة لبقائه وديمومته.

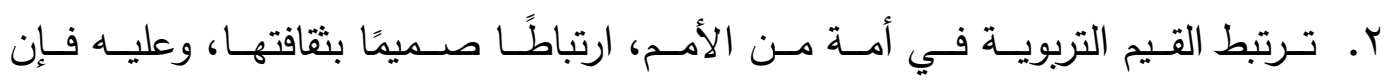

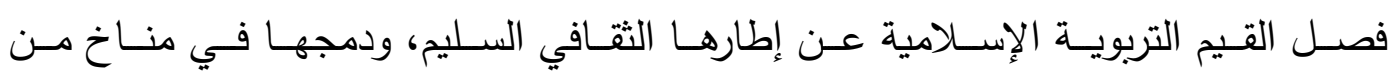

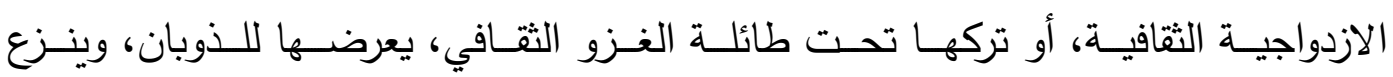

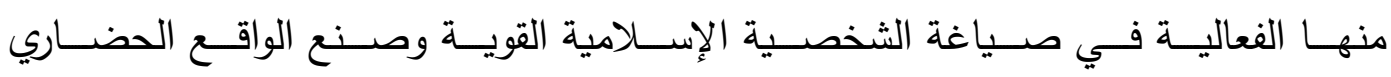
السليم.

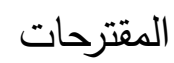
1. ـ. دراسة القيم في المناهج الدراسية الحديثة في المراحل الدراسية الدختلفة

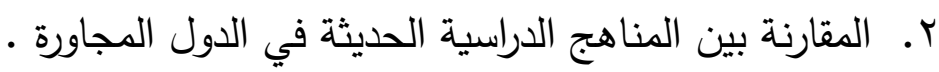
الكلمات المفتاحية : القيم ، المناهج الاراسية الفصل الأول أولاً : مشكلة البحث الاول

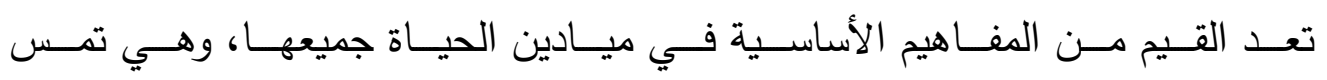

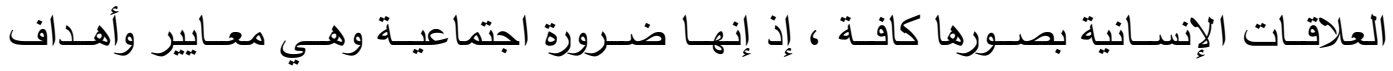

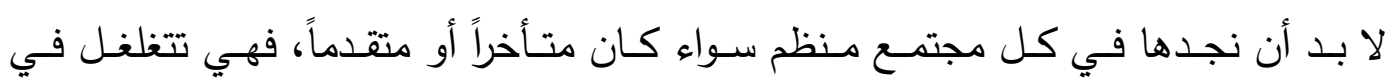


نفـوس الأفـراد على شـكل اتجاهـات ودوافـع وتطلعـات، وتظهـر فـي السـلوك الظـاهري

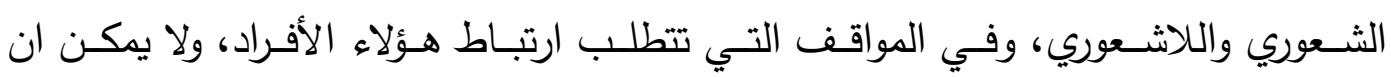

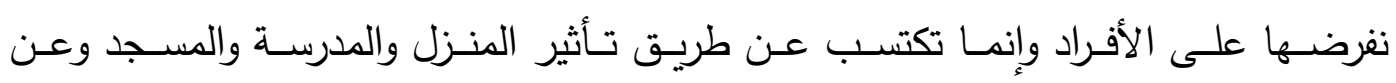
طريق الأصدقاء والأقران والقادة خارج المنزل

وتؤثر القيم في بنـاء المجتهع ووحـدة تماسكاه، إذ يـؤدي اتسـاقها في نظـام قيمسي

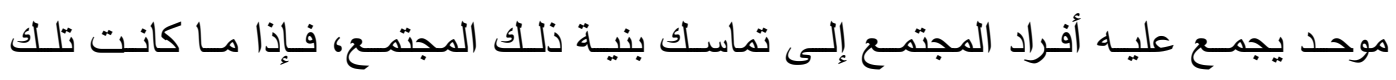

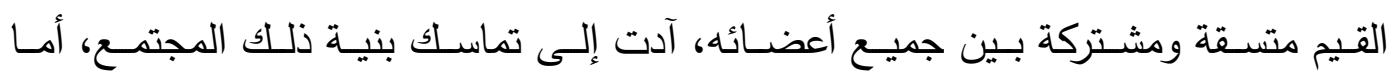

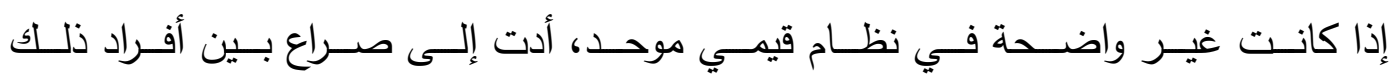

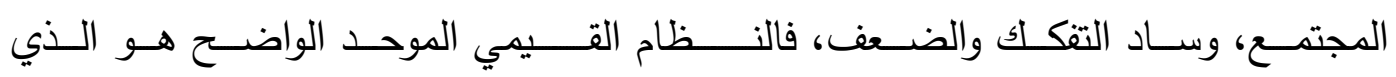

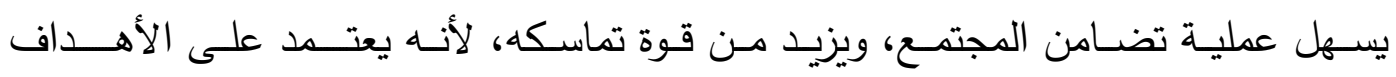

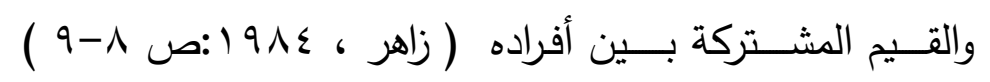

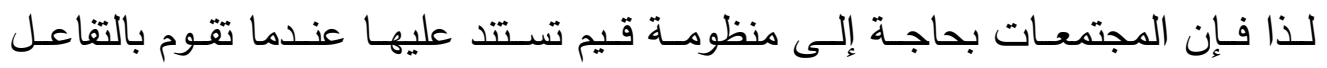

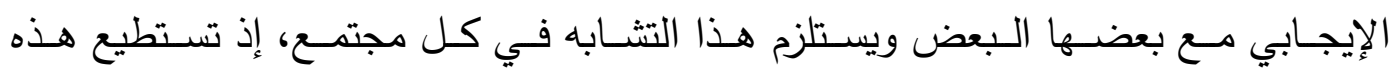

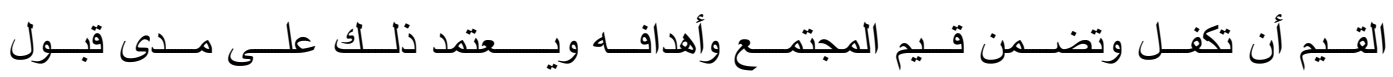

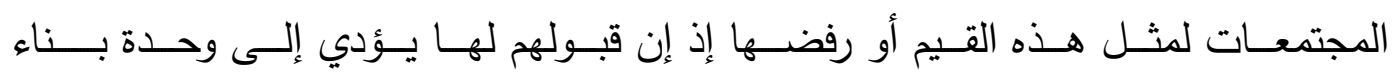

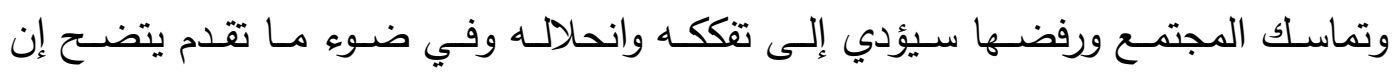

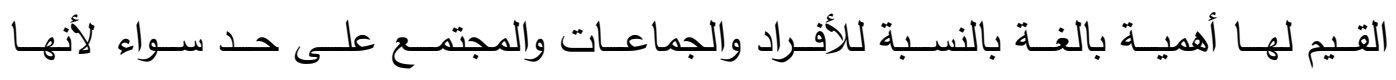

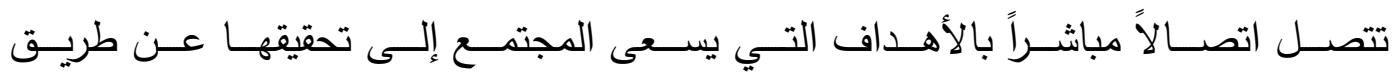

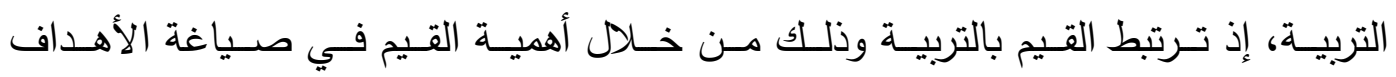

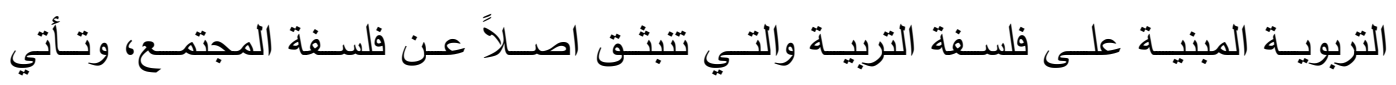

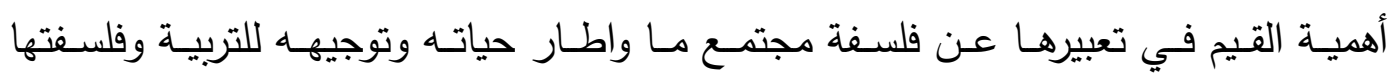

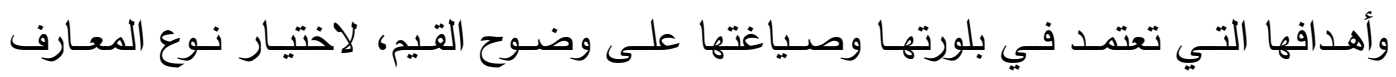

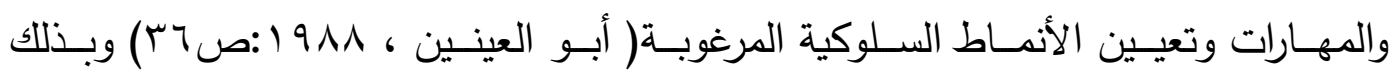

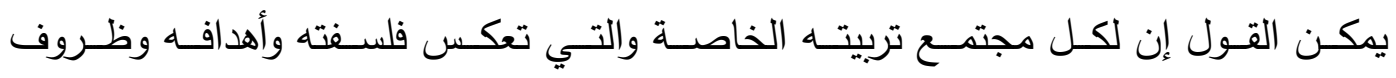

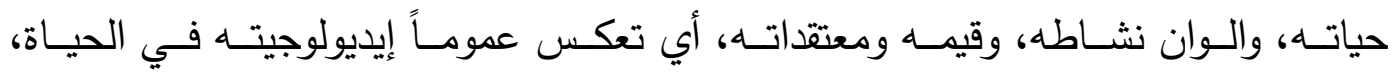

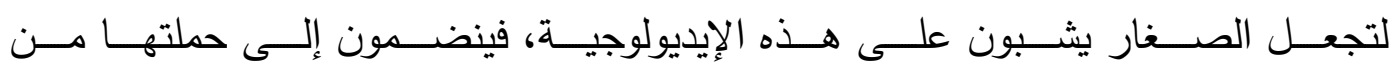

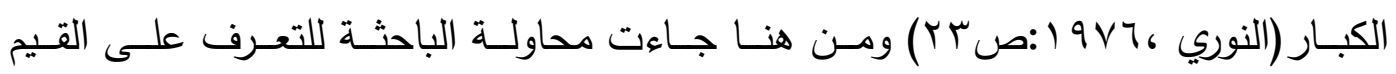

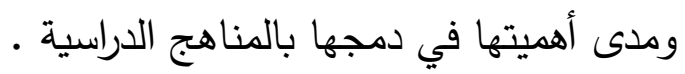




\section{ثانياً: أهمية البحث}

تشـكل المنظومــة القيميـة للمجتمـع أهـم وسـيلة لحمايتــهـ مـن التشـتـت والانــثار وتضــمن لـه الاسـتمرارية مـن دون فوضـى ولـيس مجـرد تعلـيم معلومــات وانمــا هـي بالدرجـة الأولى عمليـة تتميـة بشـرية سـليمة وبنيـة متماسـكة مـن القـيم السـوية) والقـيم

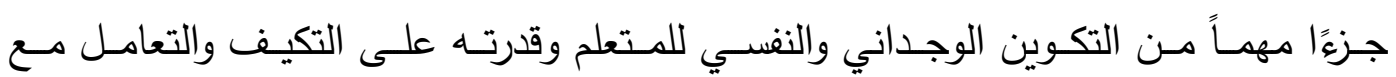

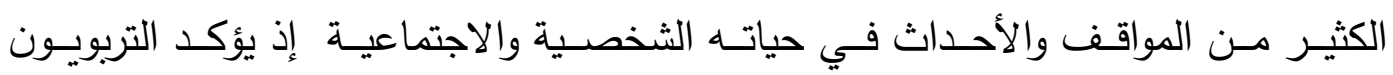
على أهميـة البُعـد الوجداني في عمليـة الـتعلم ، ويـرون أن تكـوين المواقف والاتجاهـات مـن خــلال القـيم التـي يكتسـبها المـتعلم خــلال وجـوده بالمدرســة لا تقــل أهميــة عـنـ

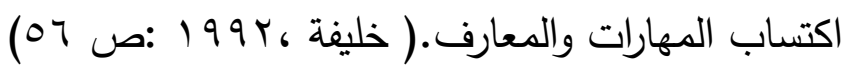
وعلى الـرغم مـن هـذه الأهميـة فـإن نـواتج التعلم في البُعـد الوجـداني، ولاسـيما في

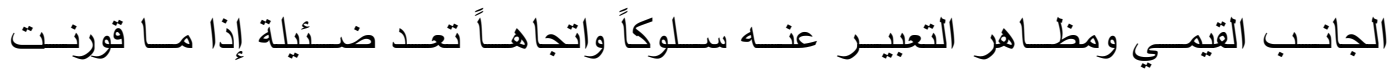

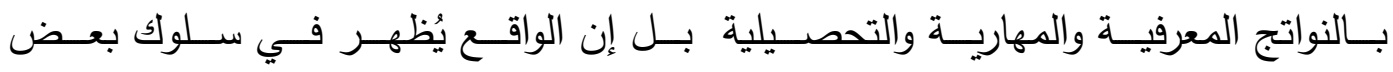
الطـلاب تثــربهم لقـيم مناقضــة وغيـر متفقــة مــع وظليفــة المدرســة وغايــة التعلـيم، ولاسـيما مـا يتعلق منهـا بالتنشـئة على قيم الصـدق والعـدل والوسـطية والاعتـدال وتقبـل

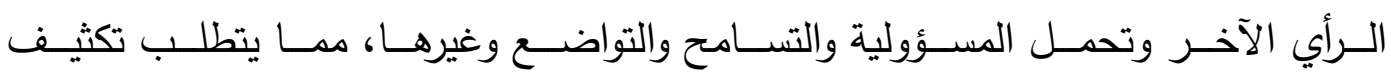
الجهود في هذا المجال سعياً لتعزيز البرامج الهادفة إلى التربية والتشئة السوية

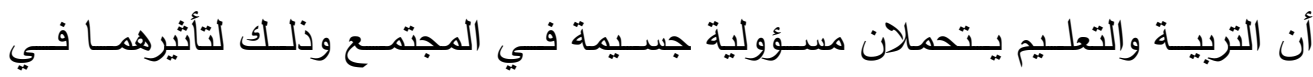
مجـال مواكبـة التقـدم العلمـي ومجابهـة تحـديات العصـر ولـدورهما الفعـال فـي بنــاء الإنسـان الـواعي والمشـارك فعليـاً وعمليـاً فـي بنـاء الحضــارة البشـرية والإنسـانية بشـكل ينسـجم مـع أصـالتنا الإسـلامية النابعـة مـن القـرآن الكـريم. ولأنتـا نحتـاج ان نعيش واقعـاً يحتـاج إلـى أحـداث تطـوير مسـمر في منــاهج التربيـة والتعلـيم في مختلف مسـتوياتها مــع تحـديث الجـادة التطبيقيــة والعمليـة لتكـون فعالــة ونتيجــة لخبـرة البـاحثين العمليـة والتطبيقيـة الطويلـة في الميـدان التربـوي والتعليمسي نسـتطيع القـول أن القـيم التـي تبثهـا المقـررات الدراسـية فـي الأجيـال سـتظل مـؤثراً علـى توجهـاتهم المسـتقبلية (الصــدي،

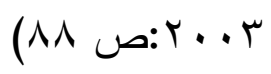

وتحقيقـاً لطموحاتتــا المسـتقبلية فـي الرفـع مــن كفــاءة وجديــة العمليـة التربويــة والتعليميـة نـرى لزامـاً علينـا أن نطـرح فكرنـا التربـوي مسـتفيدين بـذللك مـن التطـورات التربويـة العلميـة ومشـاركين في تعـديل وتصـحيح المسـيرة التعليميـة لمـا فيـهـ مـن خدمـة للمجتمـع والجيـل الصـاعد خاصــة ان الثـكوى مـن قصـور منـاهج التربيـة والتعلـيم في في

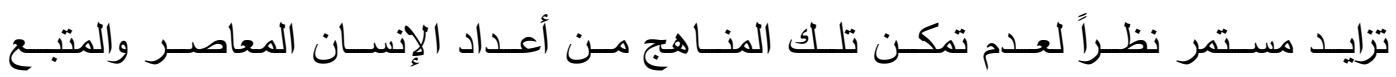




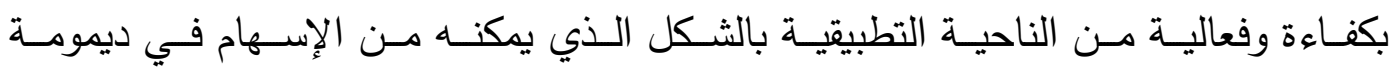

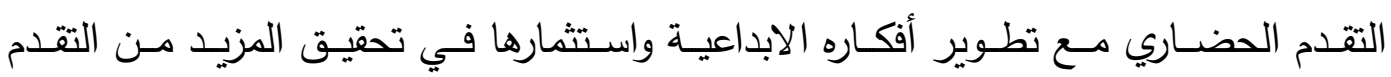

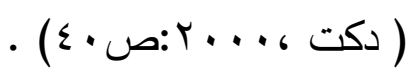

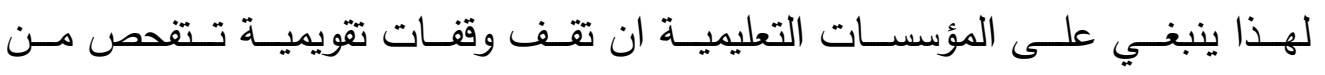

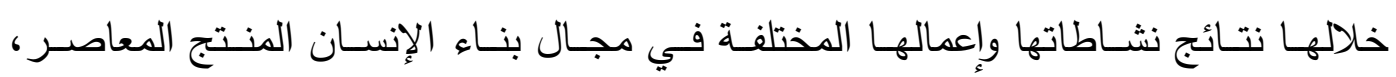

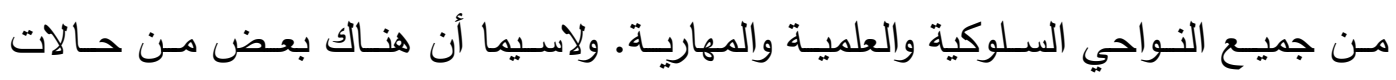

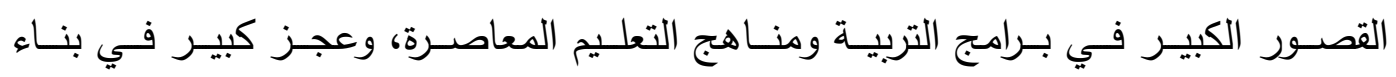

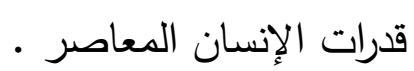

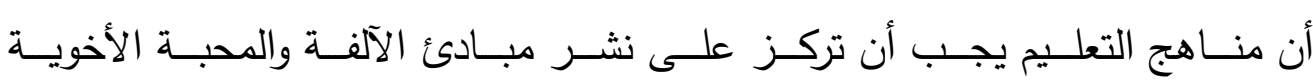

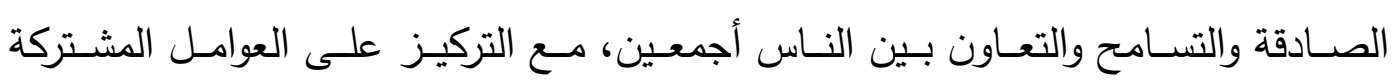

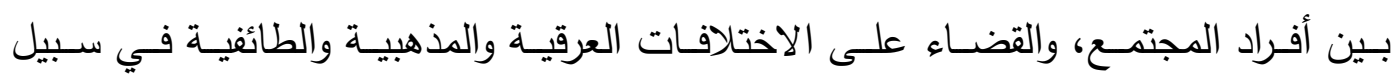

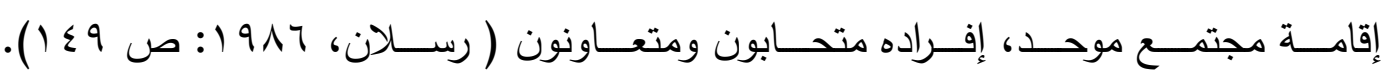

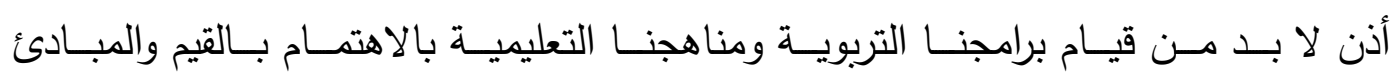

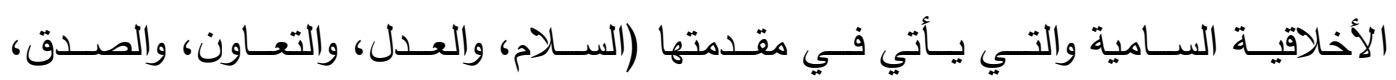

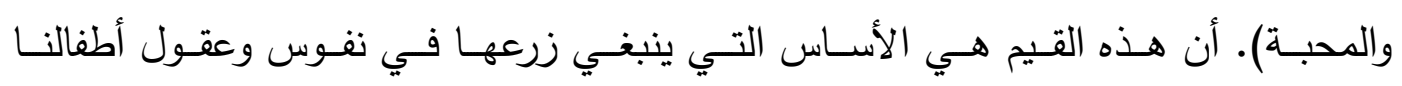

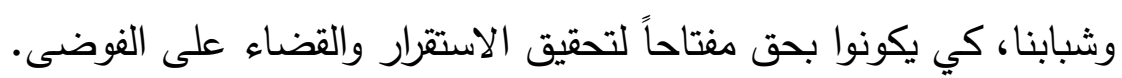

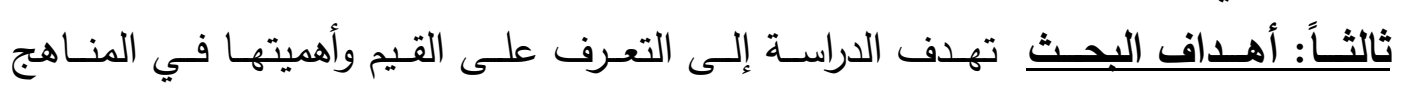
الدراسية رابعـاً : حدود البحث اقتصـرت حدود البحث على الأدبيـات التي تسهم في تحقق أهدافه الفصل الثاني (منهجية البحث) الثناه

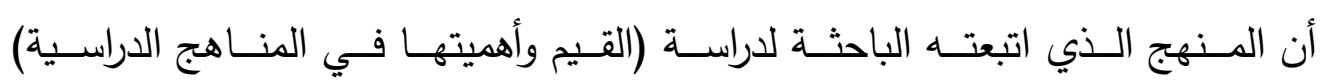

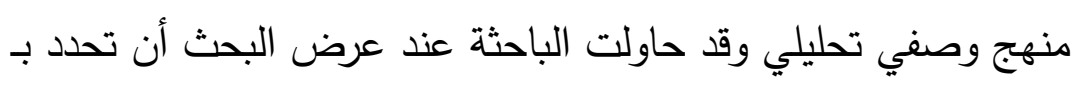
أولاً: مفهوم القيم وخصائصها ثانياً :خلفية نظرية عن معنى القيم وخدائمنها

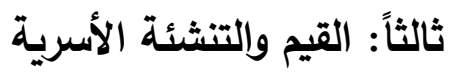
رابعاً: القيم والتنشئة السياسية الأئة الاسية خامساً: الآليات التربوية لإدماج القيثة في القياسية المناهج الاراسية 
أن الله جعـل الإنســان خليفـة فـي الأرض، وميّـزه بحسـن التركيـب وحســن التعـديل

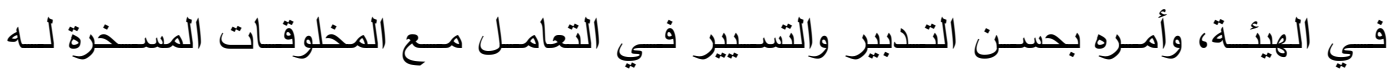
عبـادة وطاعـة للخـالق، وهـذه الصـفات تمتـــاز بالثبـات والـدوام والإطـلاق وعـدم التغييـر التي تكتسبها القيم التي زرعها الله في الإنسان حين نفخ فيه من روحهاه

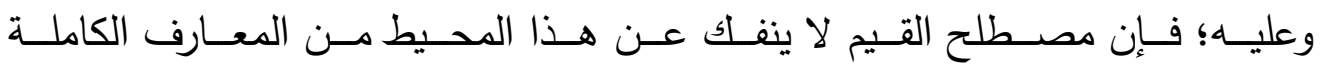
المتكاملـة، وعلى هذا المعنى تدور تعـاريف كثير مـن البـاحثين المعاصـرين في مجـال

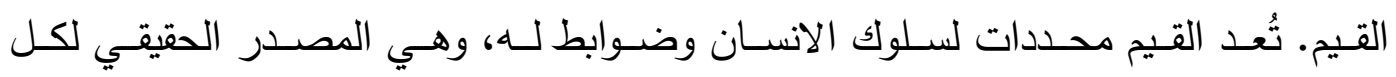

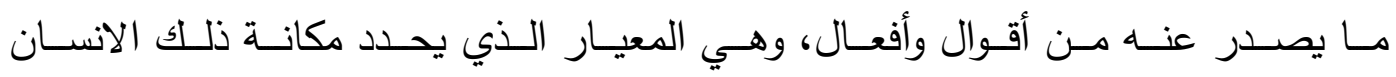

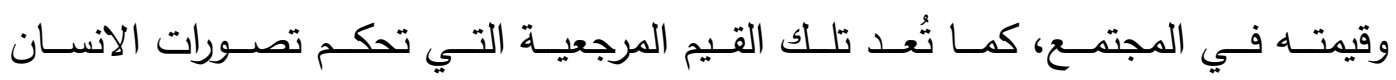

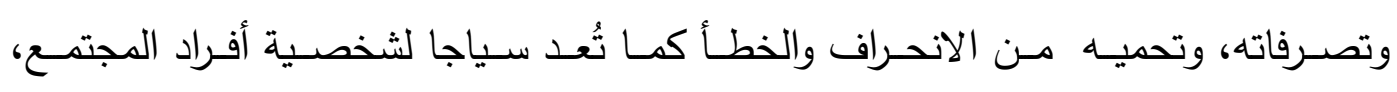
وقوة دافعة لها نحو المحافظة على البقاء والتطور

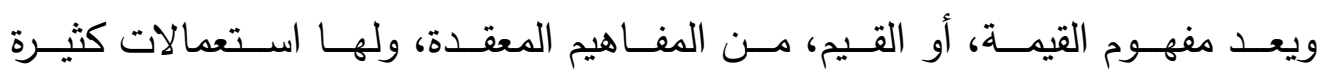

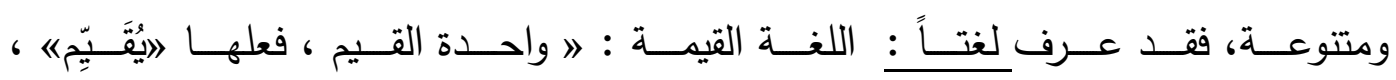

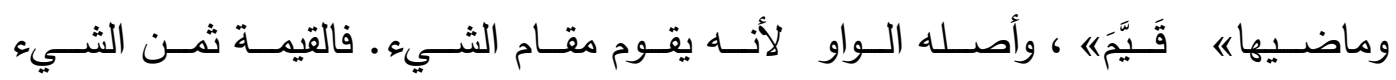

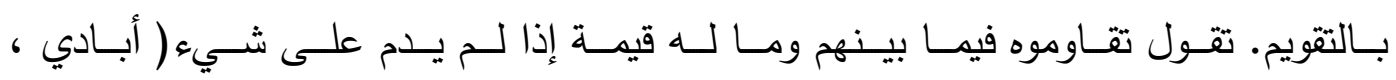

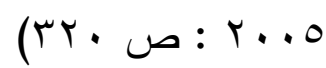
أمسا أصطلاحاً فقد اختلفوا الفلاسفة والمفكرين المحدثين في تعريف معنى القيم التي تشكلت في ضوئها أهداف التربية فهي تختلف من مجتمع إلى آخر إذ اختلف الفلاسفة فيما بينهم في تفسيرها، ففسرها بعضهم تفسيراً بيولوجياً ومنهم من فسرها تفسيراً اجتماعياً، واختلفوا

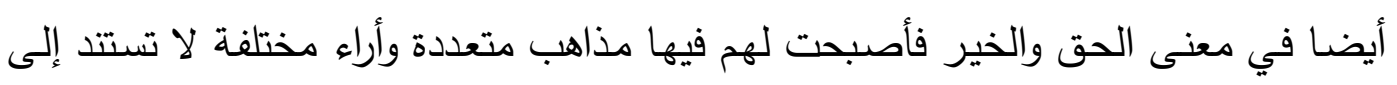
أصل ثابت ومنبع واحد، فنرى" Kanfochuos كونفوشيوس " يؤمن بان المرو يولد مفطوراً على الخير وفي ذلك يقول: ((إن الناس يولدون خيرين سواسية بطبيعتهم، وكأنهم كلما شبوا

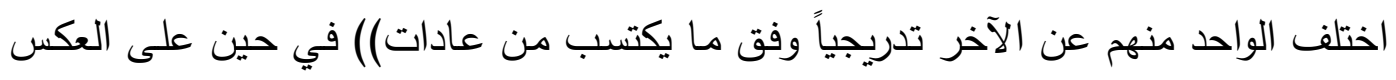

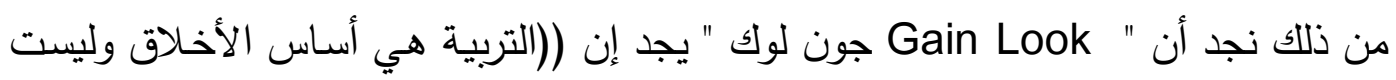

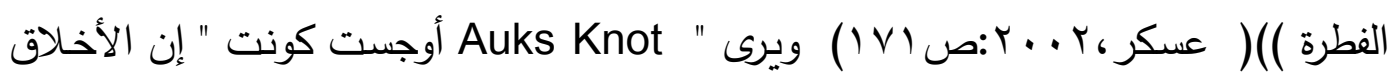

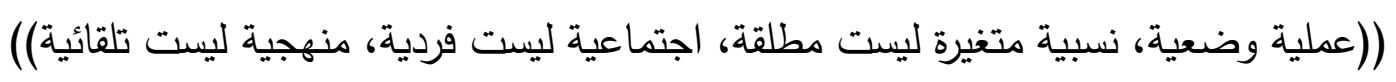

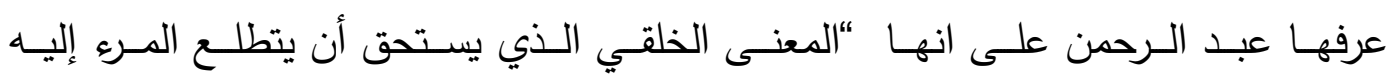

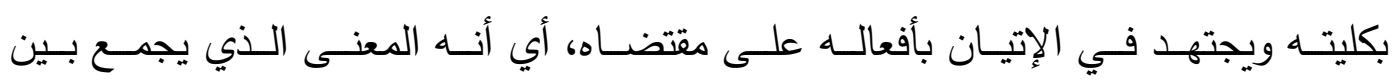




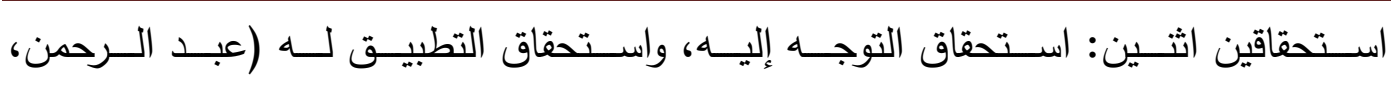
(I)

وِيـذهب التربـوي الفرنسـي (غـي روشـيه ، متـأثرا في ذلـلك بكـل مـن ( دوركـايم )

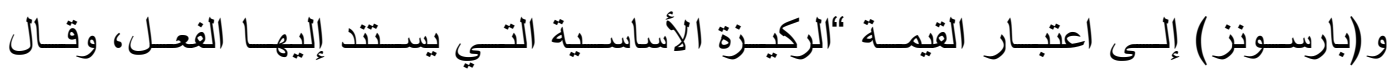

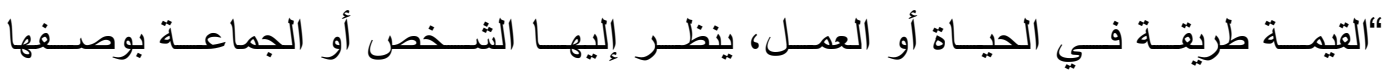

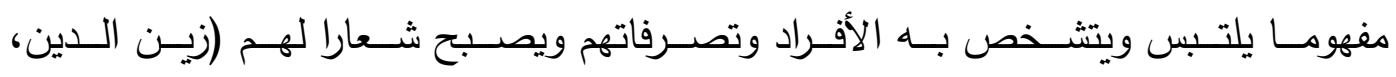

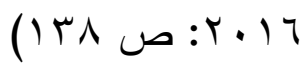

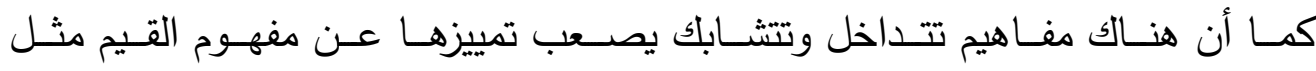

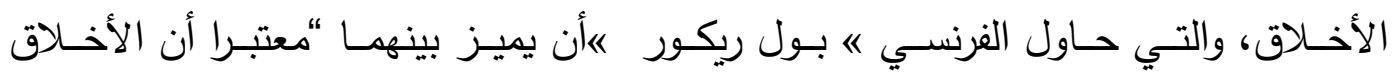

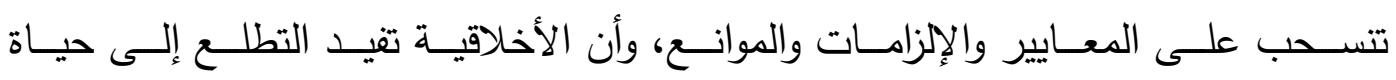

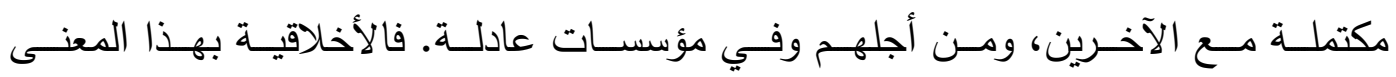

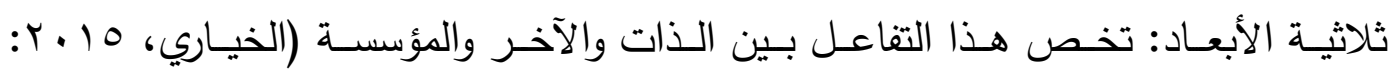

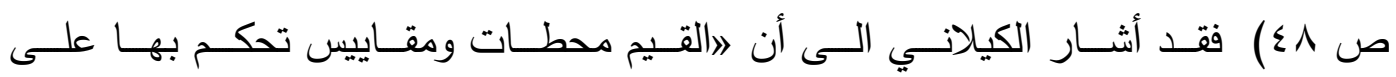

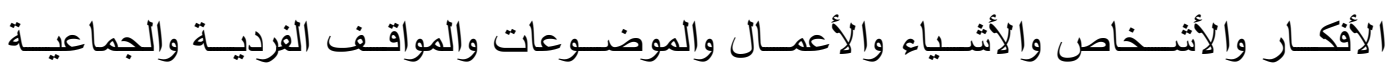

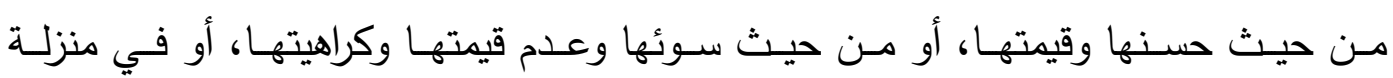

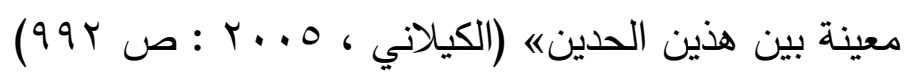

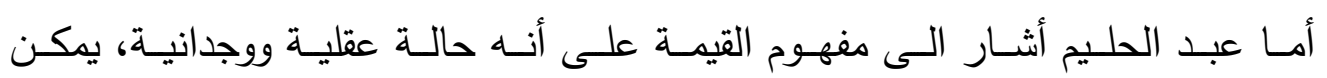

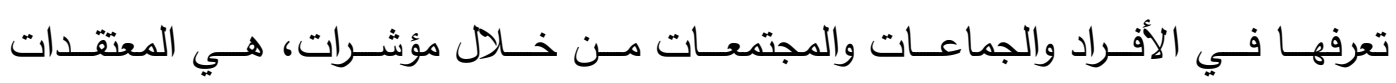

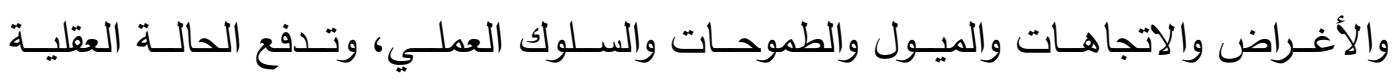
والوجدانيـة صـاحبها إلـى أن يصـطفي بـإرادة حـرة واعيـة وبصـورة متكـرة نشـاطـاً إنسـانياً

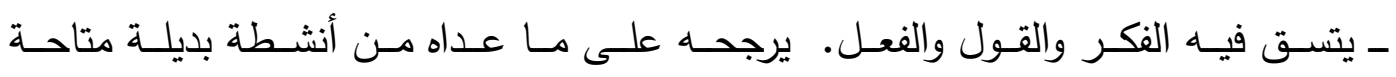

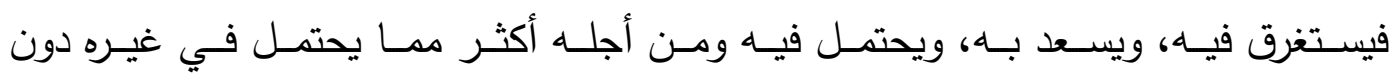

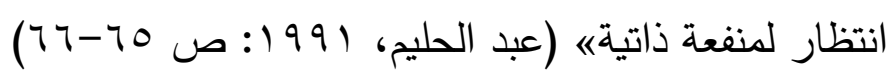
خصائص القيم

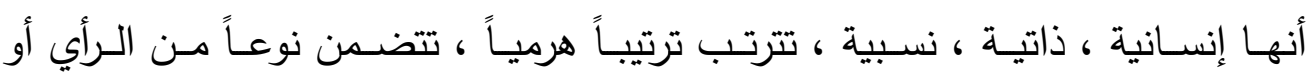

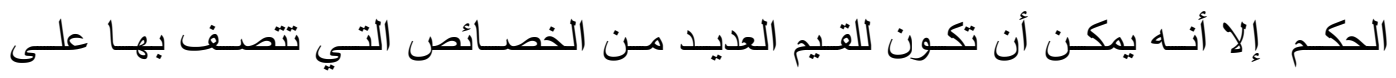
النحو الاتي : (النيات: 1. الثبات:

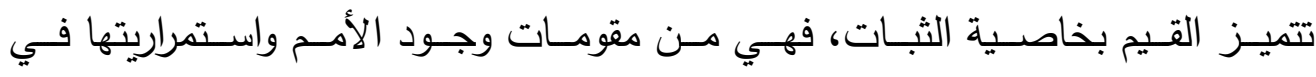

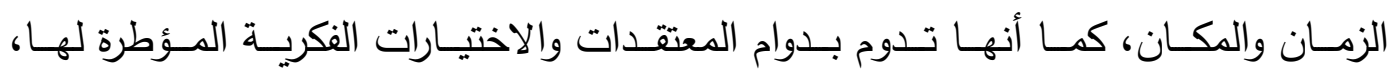




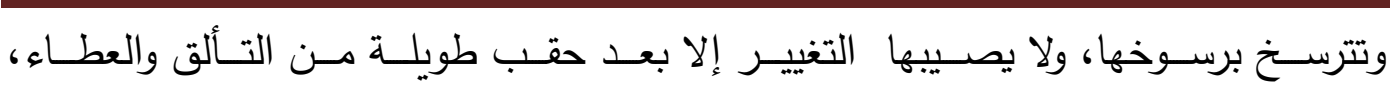

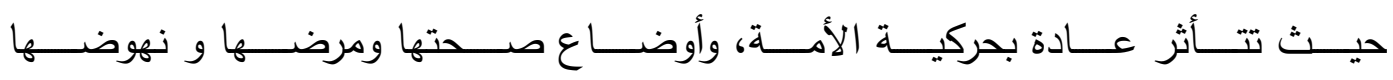

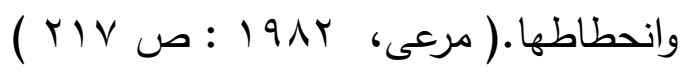

r. الفاعلية:

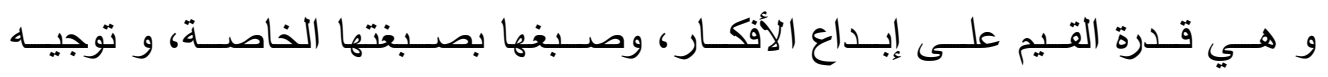

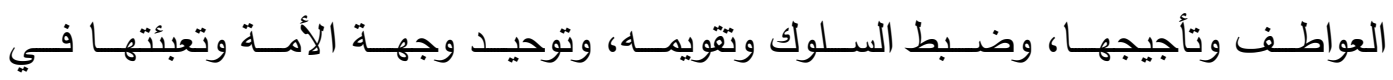

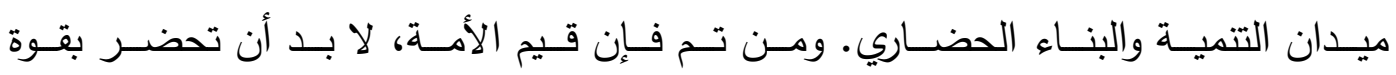

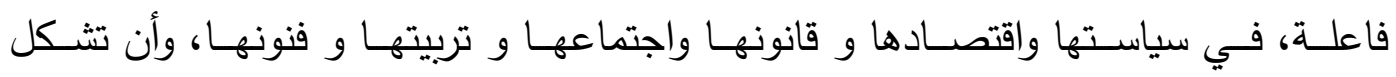

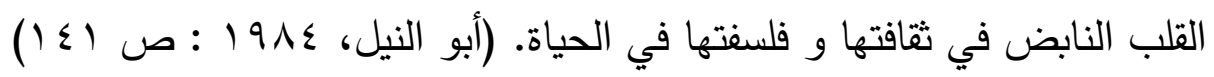

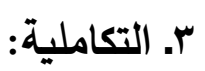

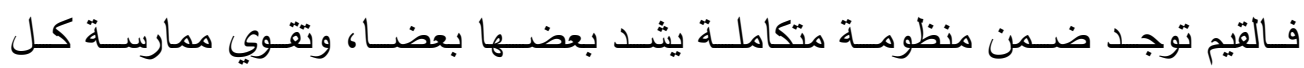

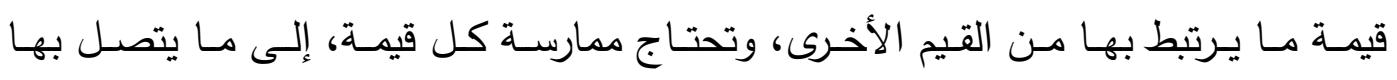

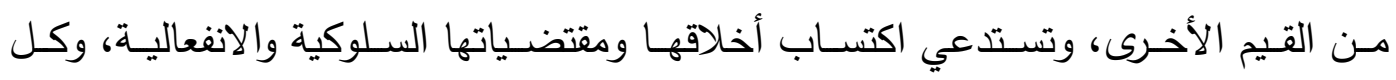

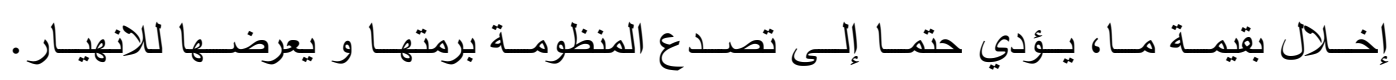

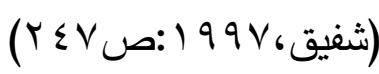

\section{ثانياً : خلفية نظرية عن معنى القيم في الإسلام}

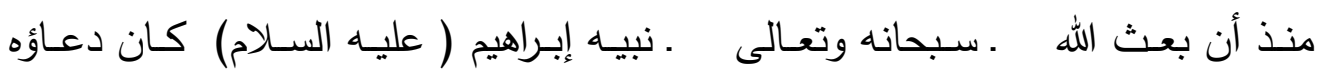

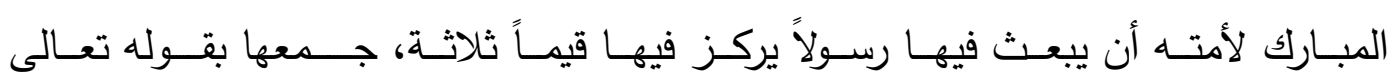

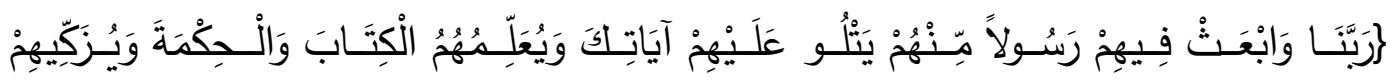

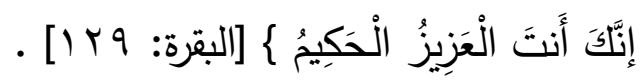

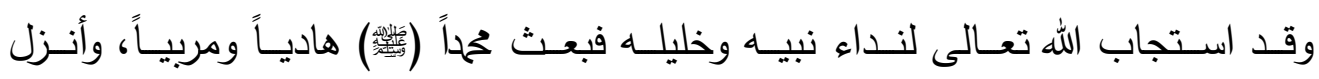

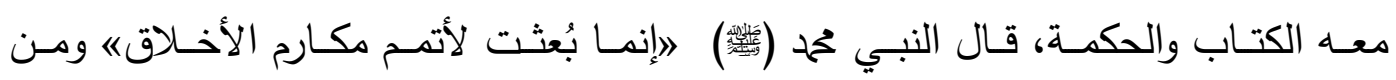

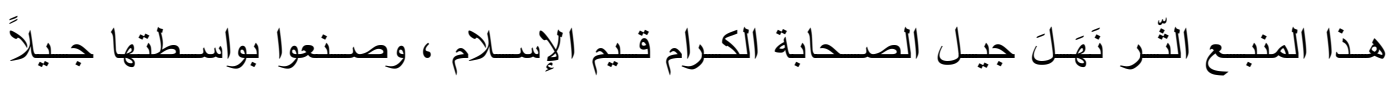
حمل راية الإسلام إلى العالم.

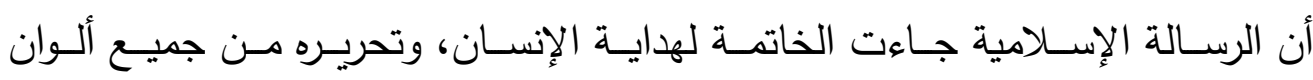

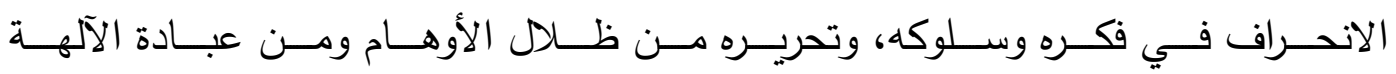

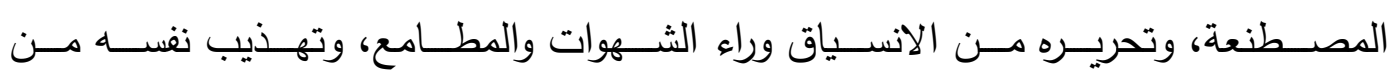
بواعث الأنانية والحقد والعدوان، وتحرير سلوكه من الرذيلة والانحطاط.

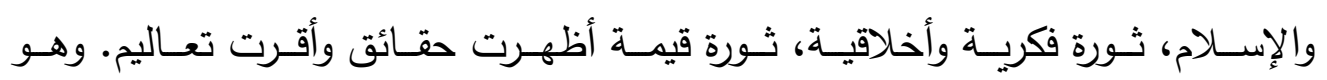

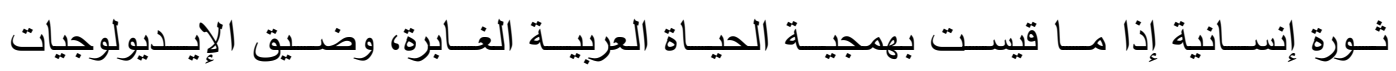


الدينيـة السـابقة مثـل الوثنيـة واليهوديـة. وهــهـ الثـورة الإنسـلامية الإنسـانية تتميـز بأنهـا

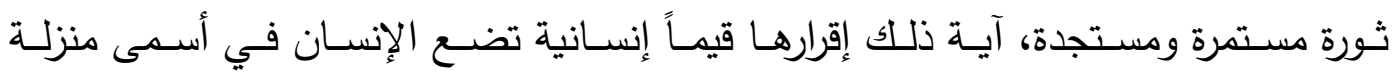
على الأرض وتحله مرتبة منفردة لا يضاهيها سواها لدى سائر الكائنات الحية.

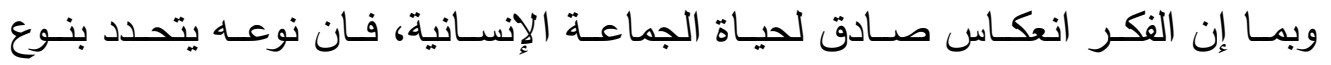

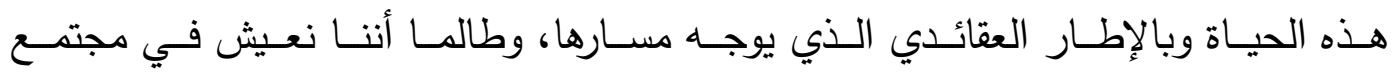

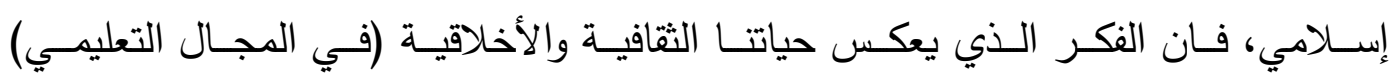

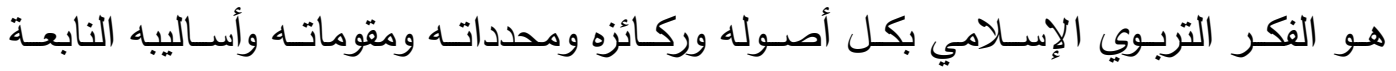

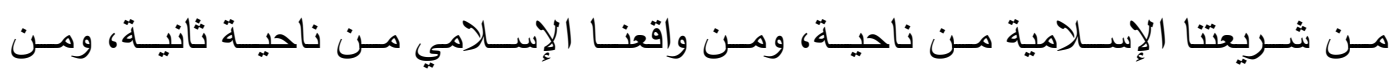
تطلعاتنا المستقبلية من ناحية ثالثة . ولقد سـلت حركـة الفكر صـفحة مـن أروع صـفحاتها في التـاريخ بظهـور الإسـلام

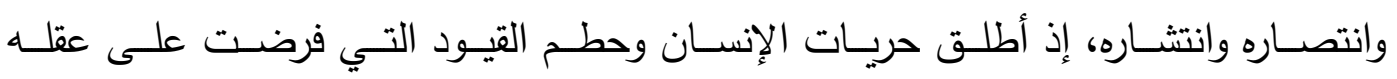

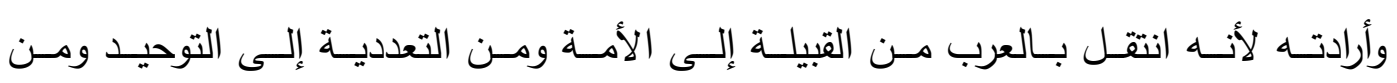

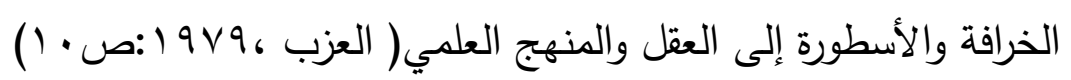

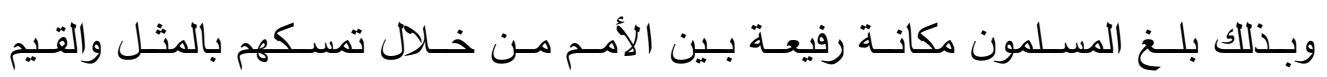

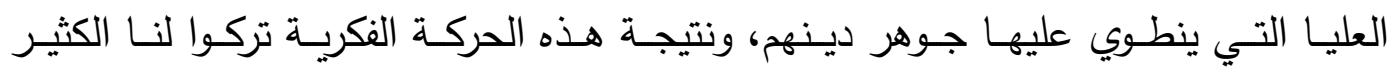

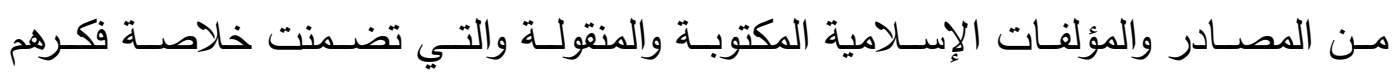

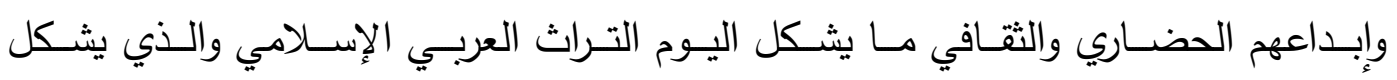

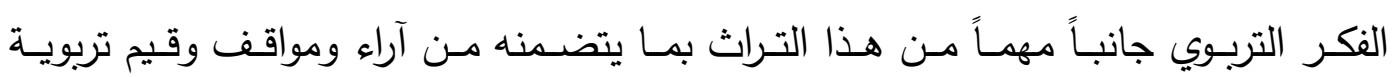

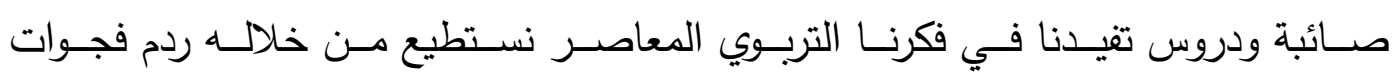
الضعف في معتقداتتا وممارستنا التربوية

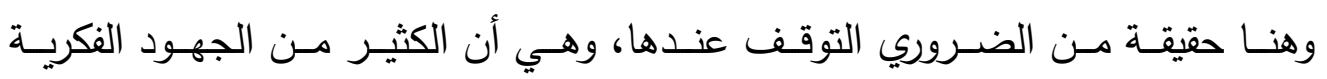

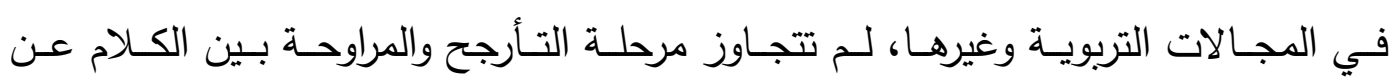

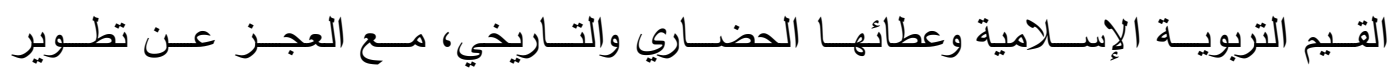

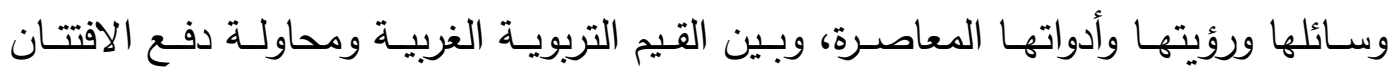

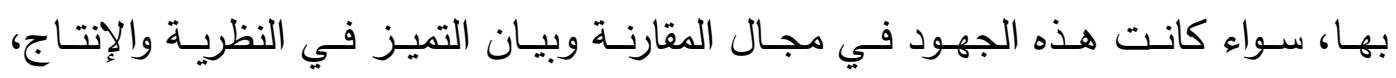

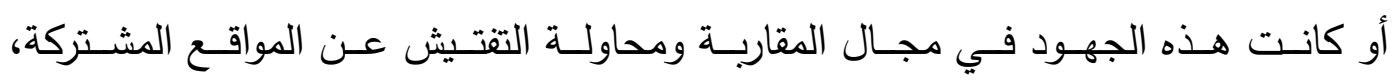

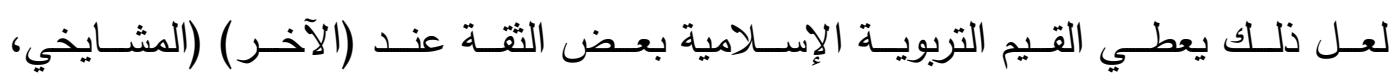
(V): (199

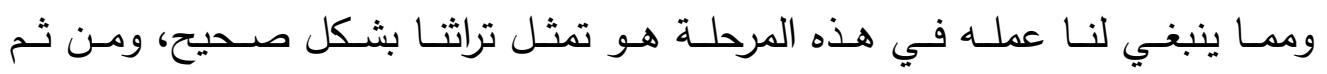

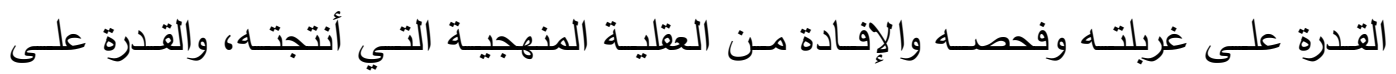




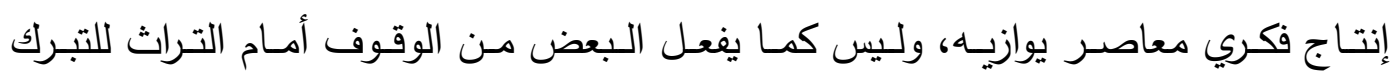

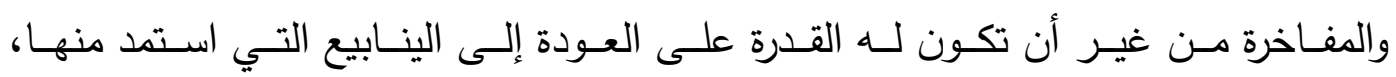

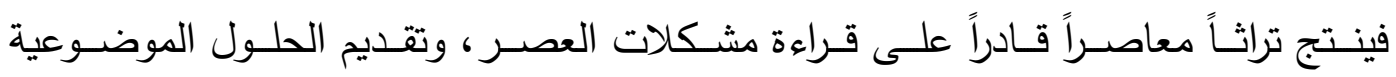

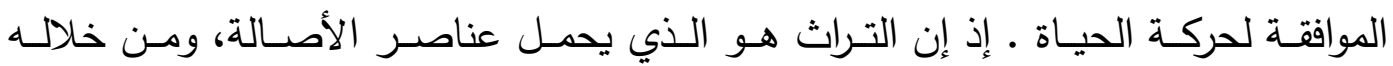

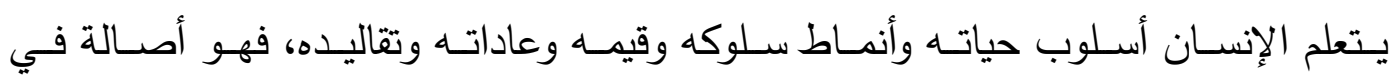

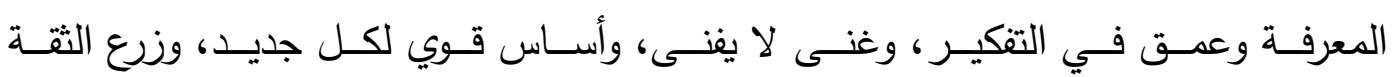

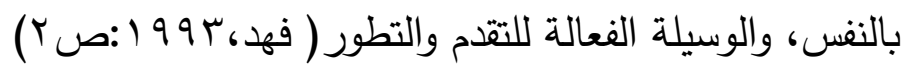
الأصول العامة للقيم الإسلامية

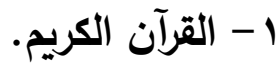

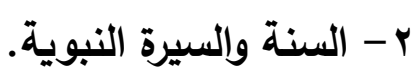
r - اجتهادات علماء التربية المسلمين. أ - القرآن الكريم: - آتهادات

إن النظـر العـام يلخص رسـالة القـرآن الكـريم في التربيـة على القيم، ومــا الأحكـام

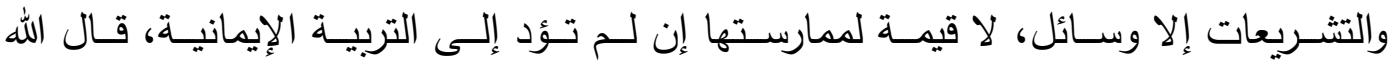

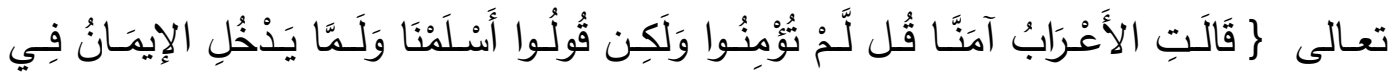

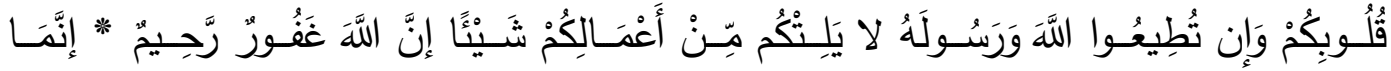

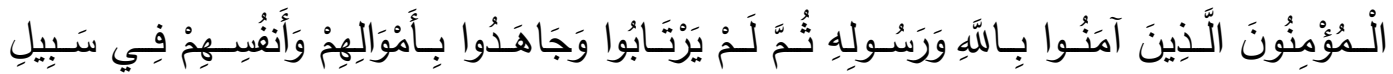

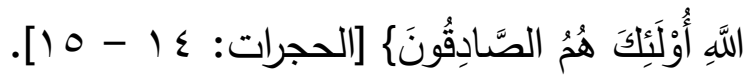

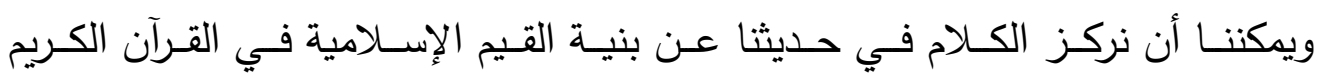
في أربع نقاط :

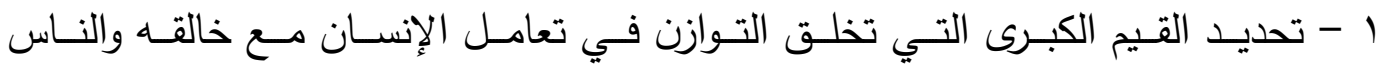

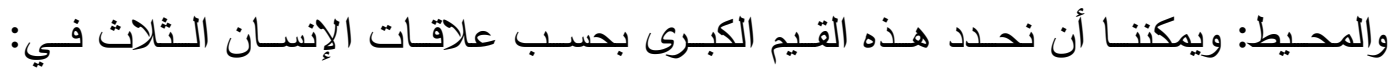
قيمة التوحيد، وقيمة الحكمة، وقيمة التسخير • قيمـة التوحيد: قيمـة كبيـرة تتفـرع عنهـا قيم العبوديـة كلهـا بجزئياتهـا وتفاصـيلها، كقيمـة وفئه التقوى، وطاعة الأوامر واجتناب النواهي،.

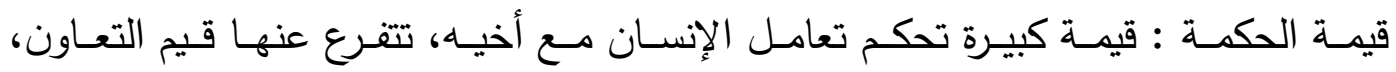

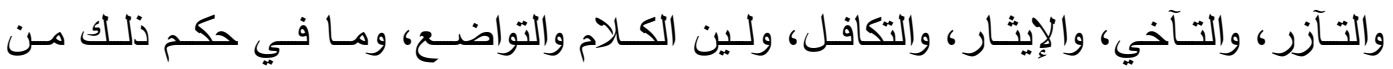
قيم تتظيم العلاقات العامة بين الناس. 


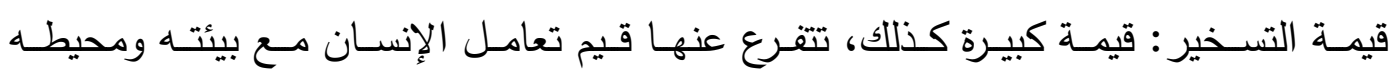

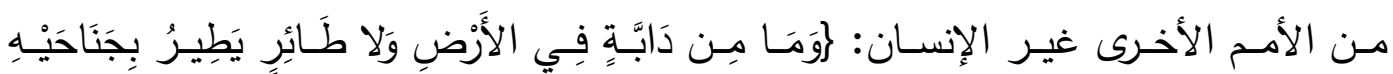

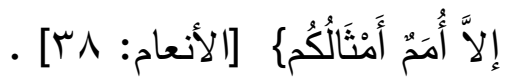

r - تكريم الرسـل وورثتهم مـن العلمـاء الحساملين لهذه القيم والناشـرين لهـا والمضـحين

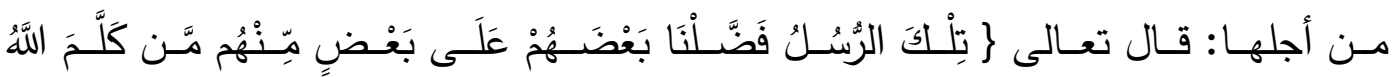

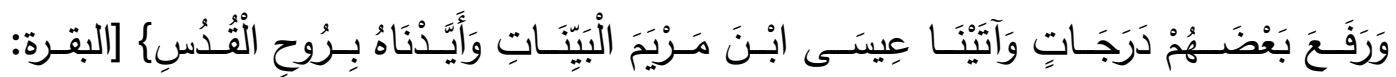

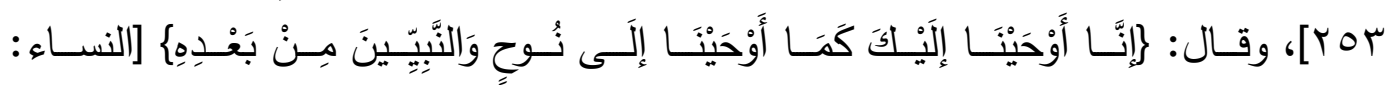

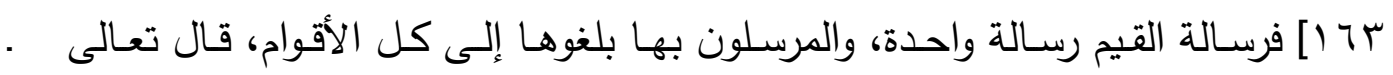

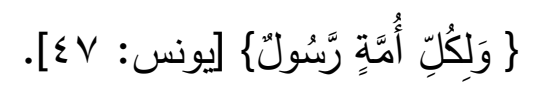

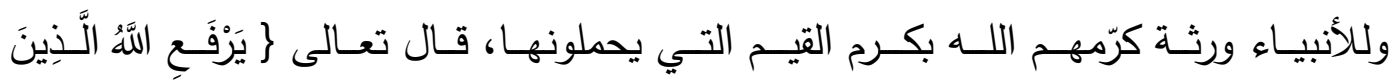

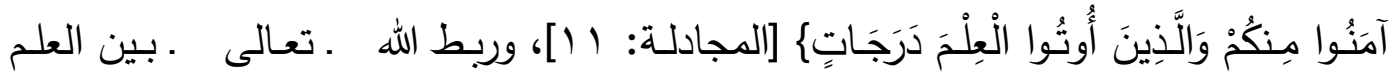

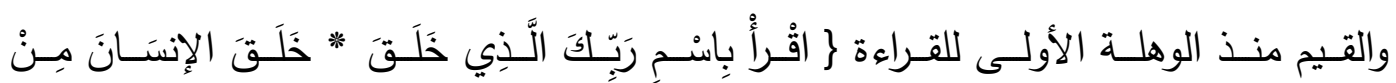

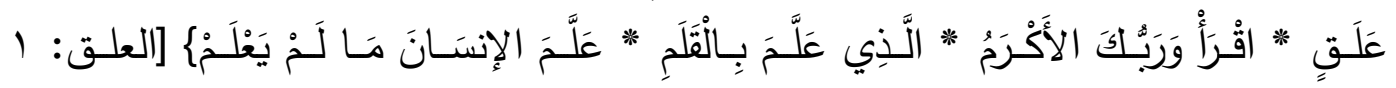

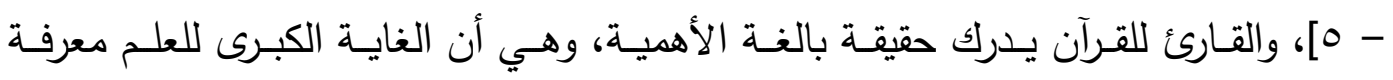
الخالق فإذا تجرد العلم عن القيم لم ينفع صاحبه.

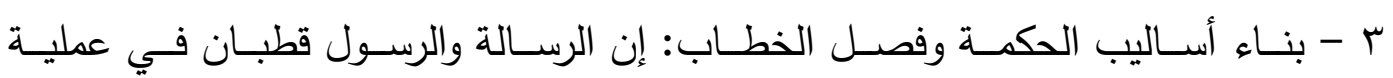

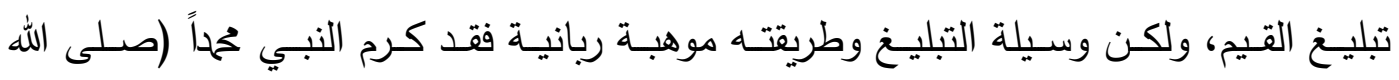

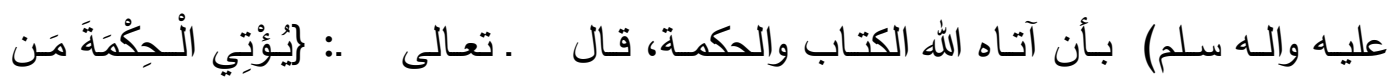

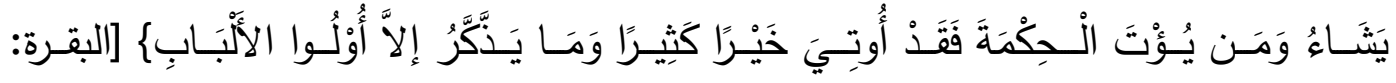

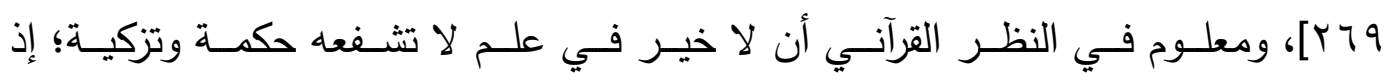
هي قيم متلازمة

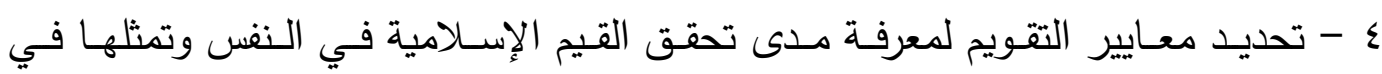

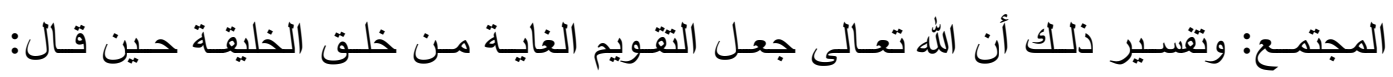

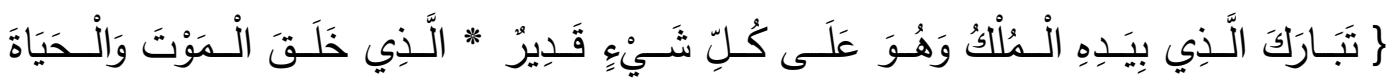

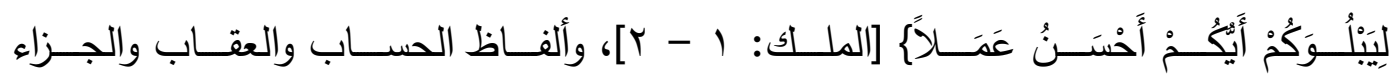

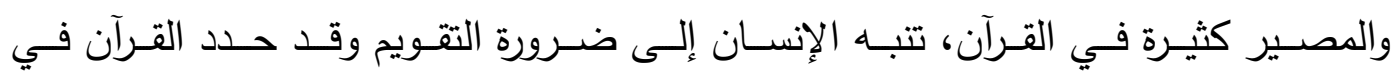

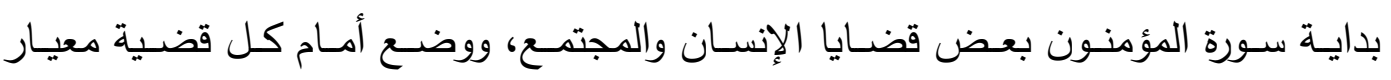

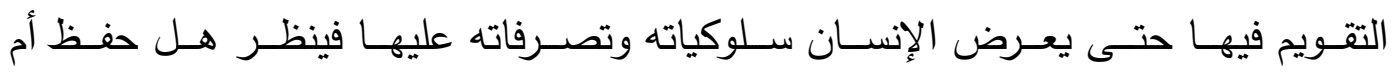


ه - اجتهاد وإبداع علماء التربية المسلمين:

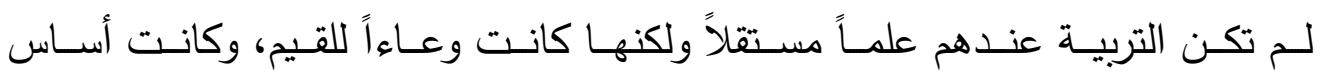

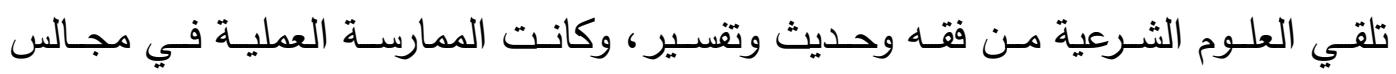

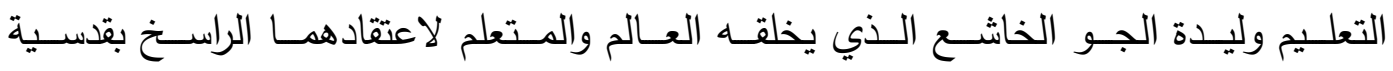

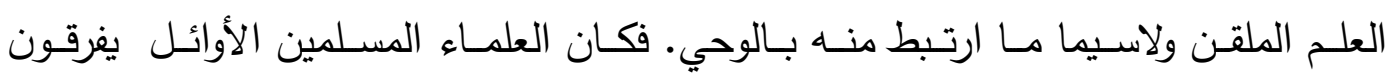

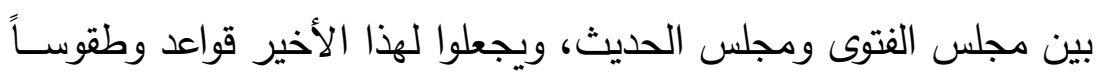

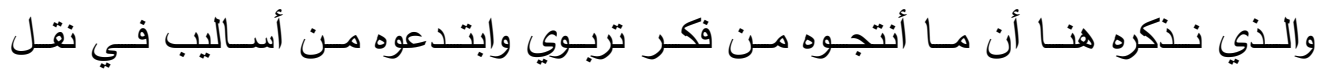

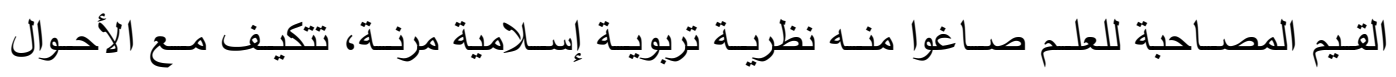

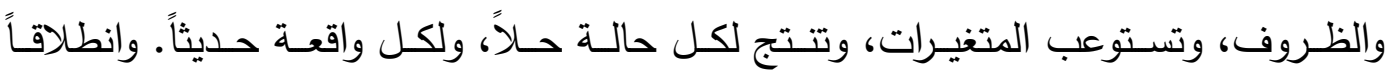

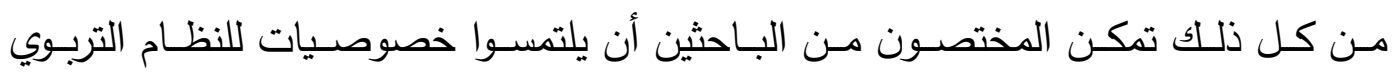

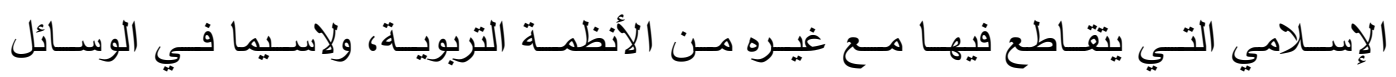

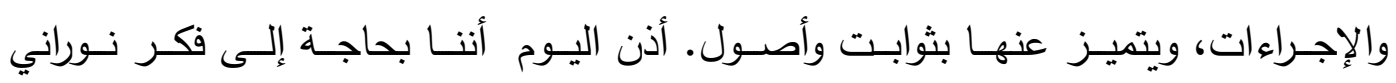

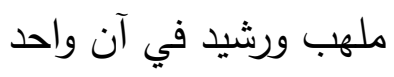
ثالثاً : القير والتنشئة الأسرية

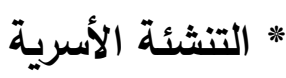

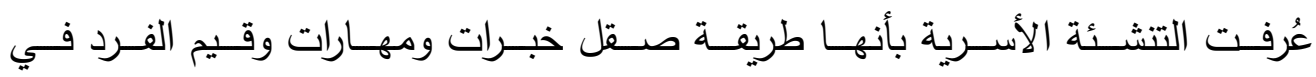

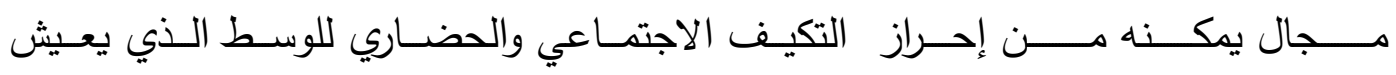

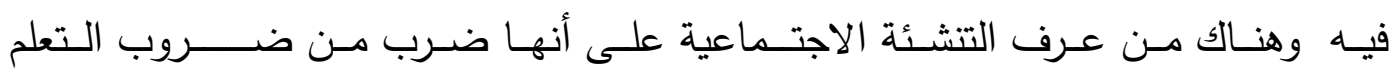

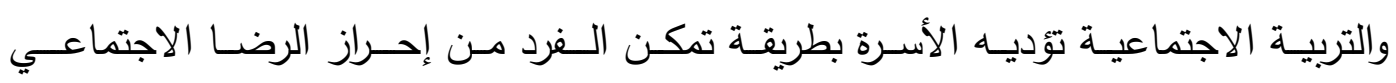

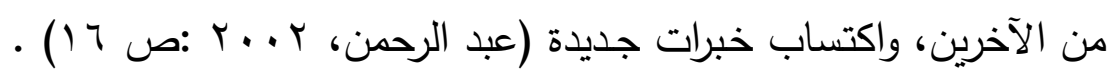

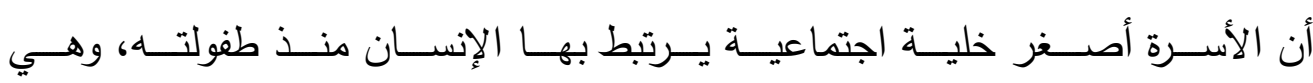

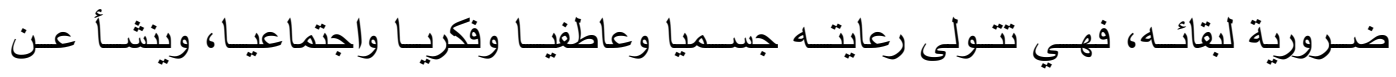

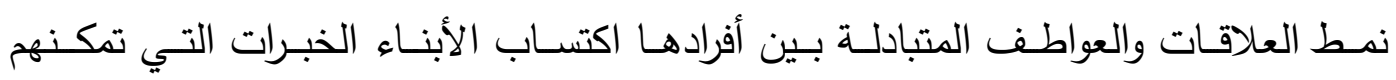

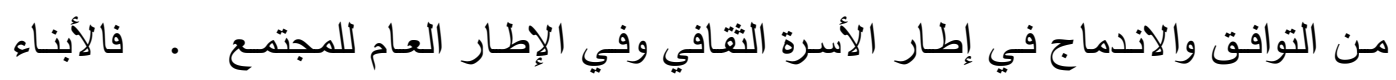

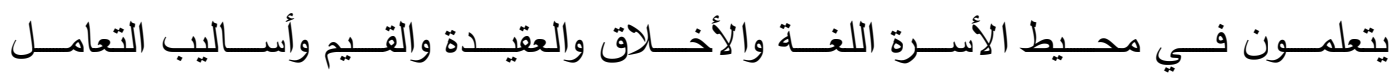

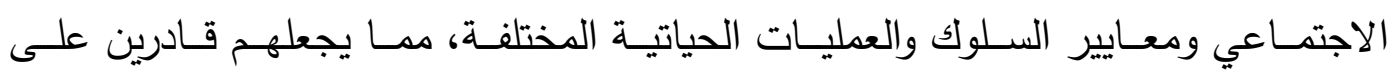

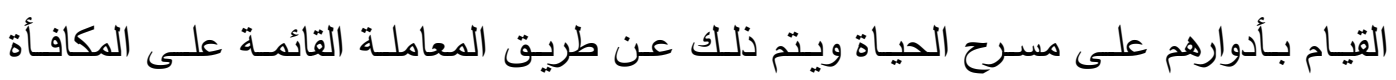

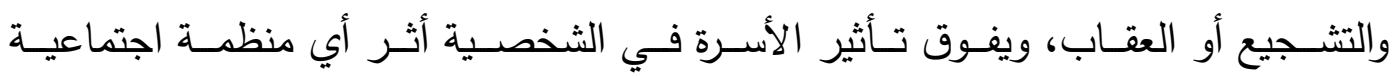

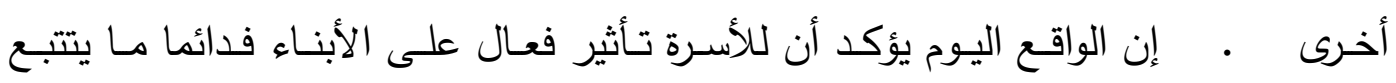

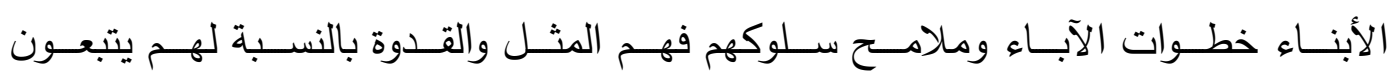




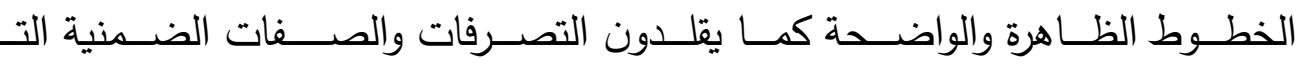

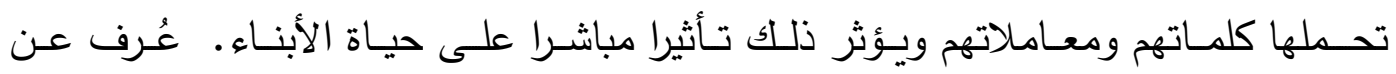

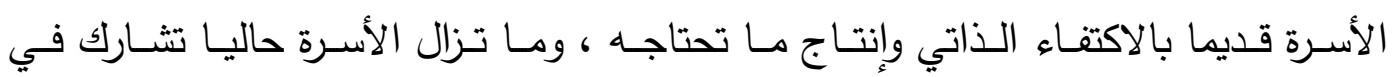

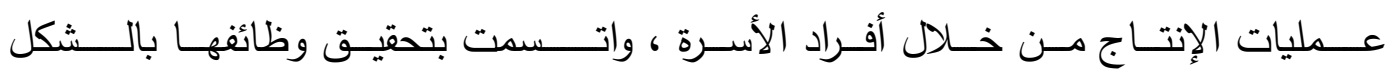

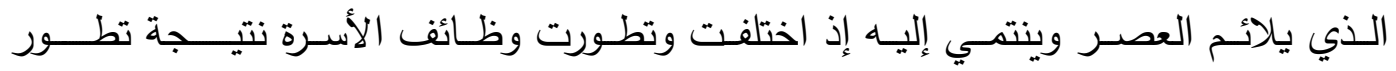

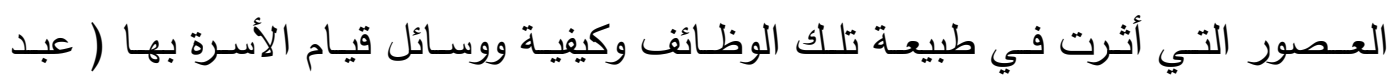

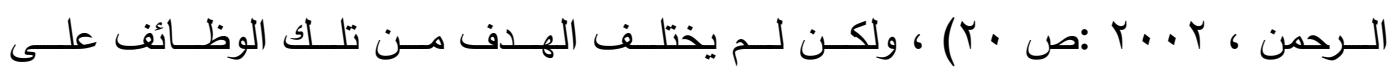

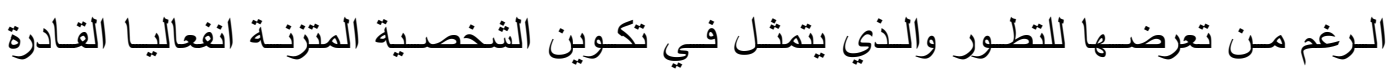
على التكيـف مـع متطلبـات الحيـاة الاجتماعيـة الوظيفـة النفسـية هـي أن تـوفر الأسـرة

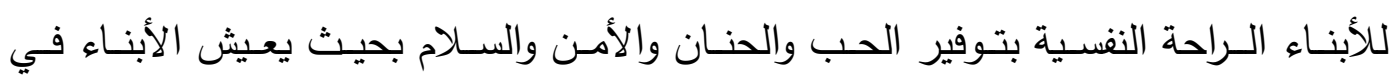

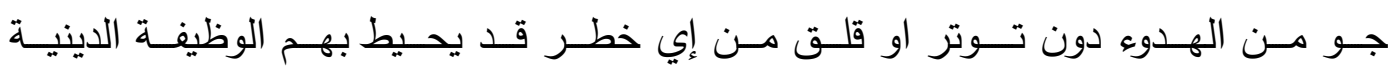

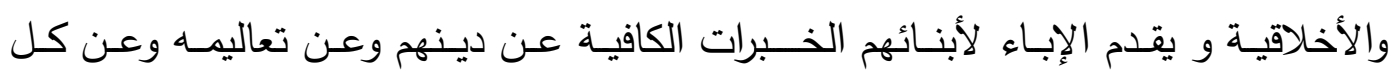

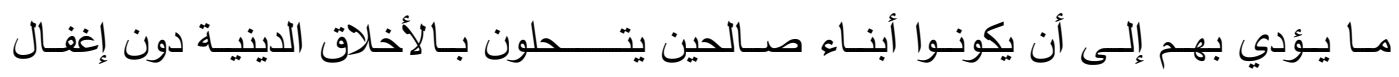

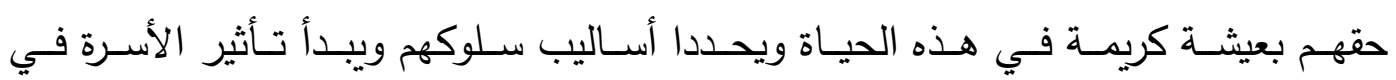

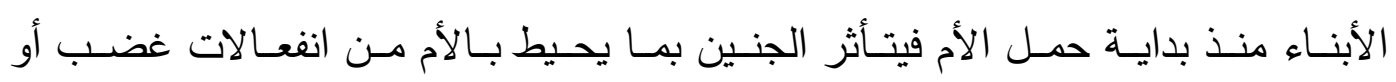

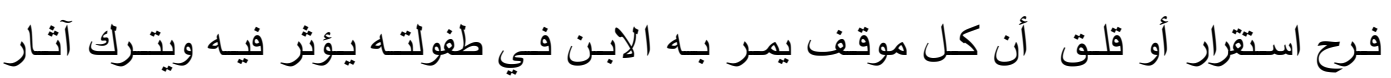

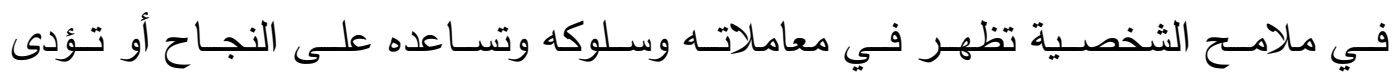

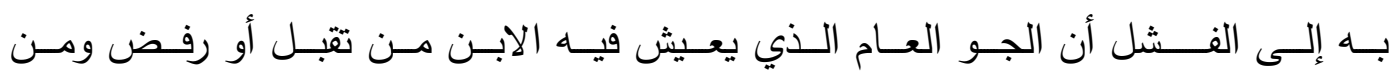

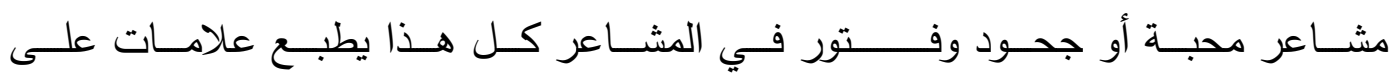

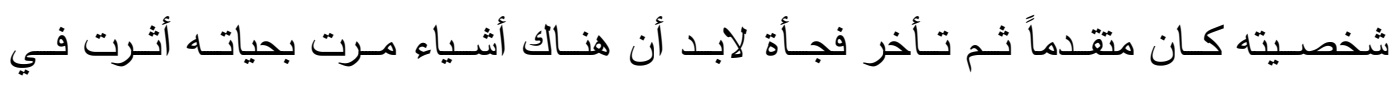
شخصيته وأوصلته لما هو فيه .

\section{ألتنشئة الأسرية في الإسلام}

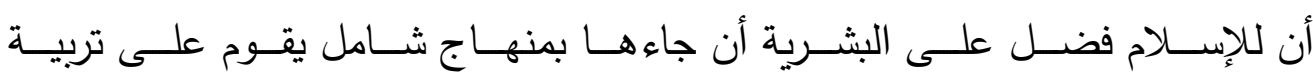

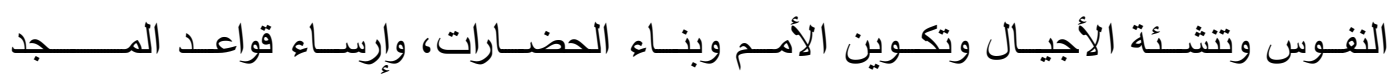

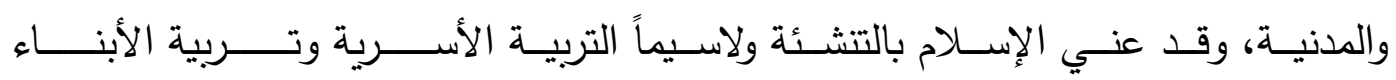

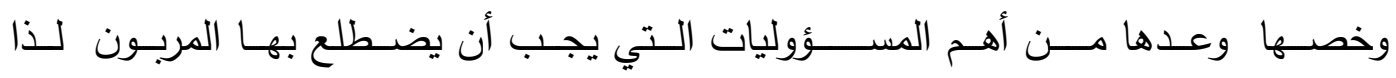

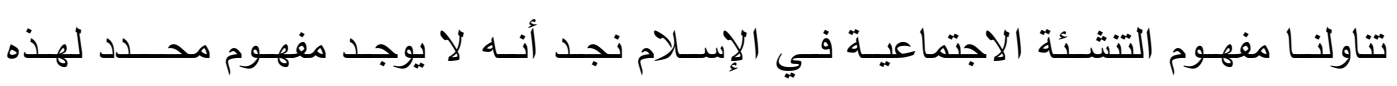

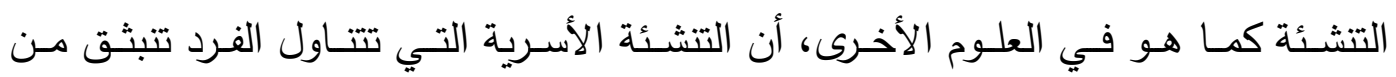

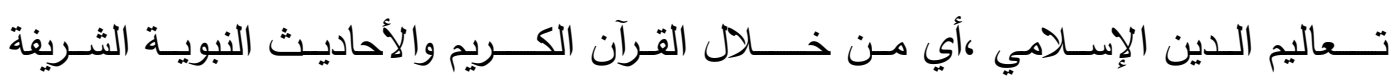

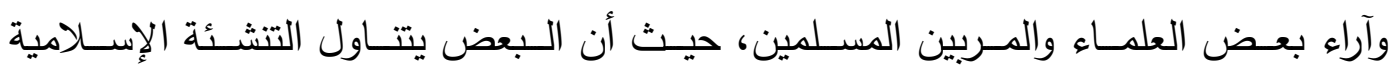


مـن خـلال تتـاول مفهـوم التربيـة الإســلامية التي تعـــتبر التشــئة الإسـلامية وسـيلة لكـي تحقـق التربيـة بهـا أهـدافها وبمـا إن التربيـة فـي المفهـوم الإسـلامي هـي إنشـاء

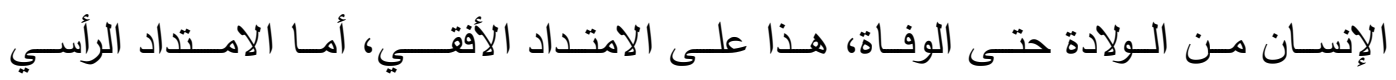

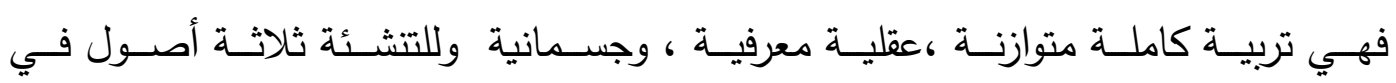
اللغة : الأول: يعني النمو، الثاني: يعني التنشئة والثالث : يعني الإصلاح ما هي أهداف التنثئة الأسرية الأنية

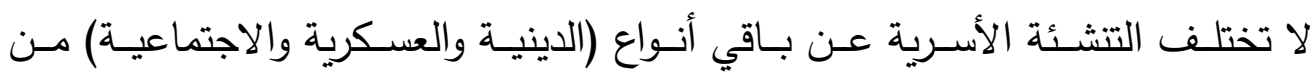

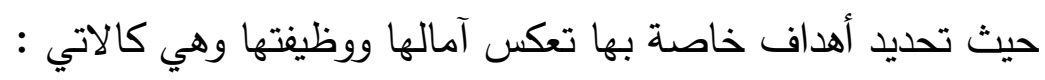

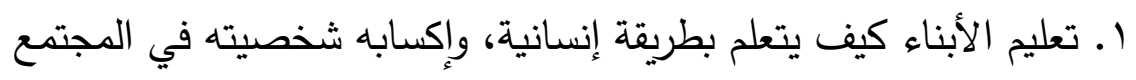

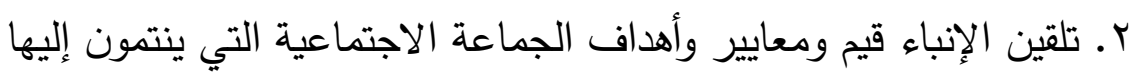

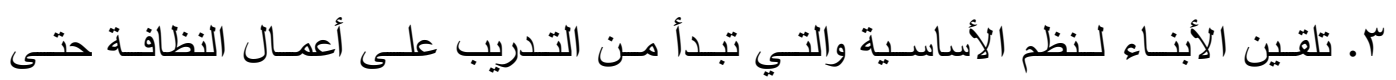

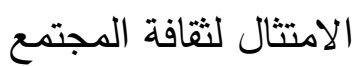

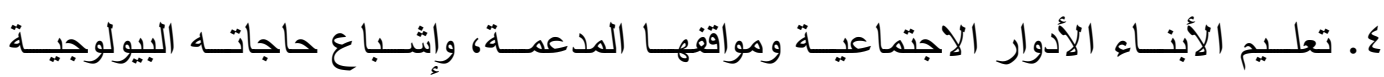

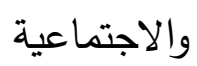
1. دمج الأبناء بالحياة الاجتماعية عن طريق إكسابه المعايير والنظم الأساسية

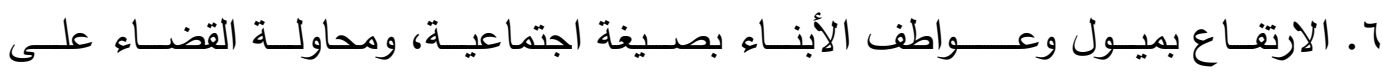

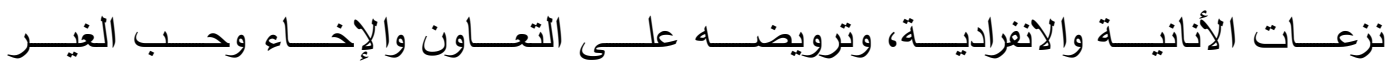

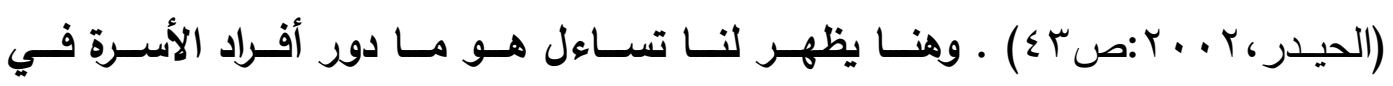

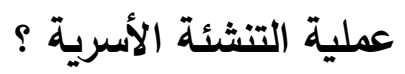

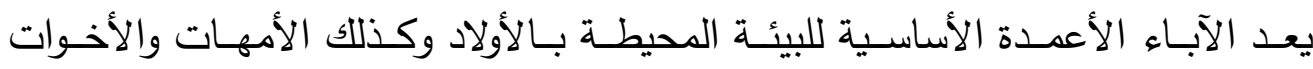

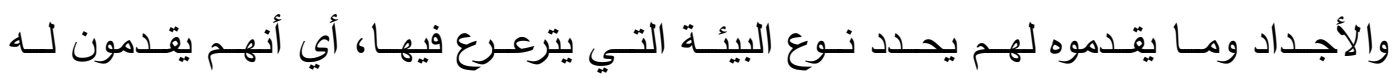

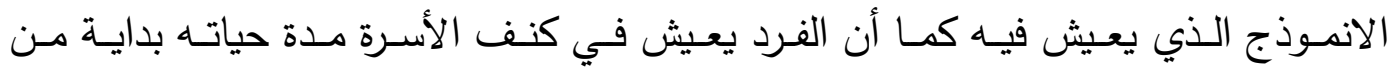

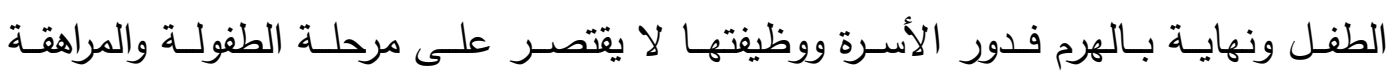

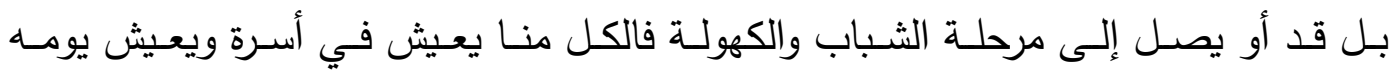

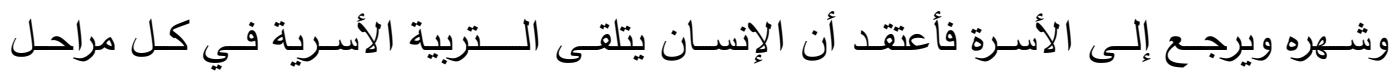

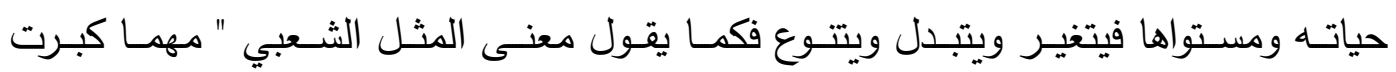

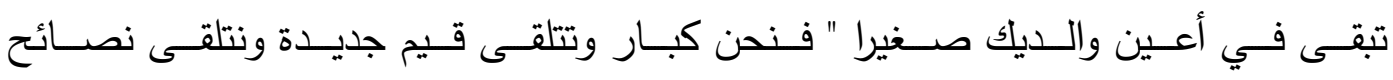

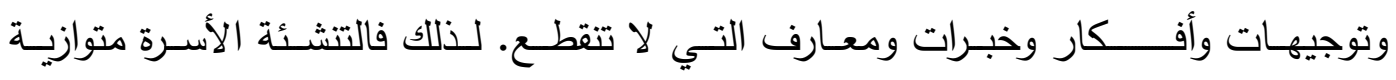

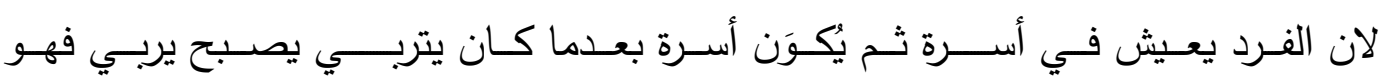




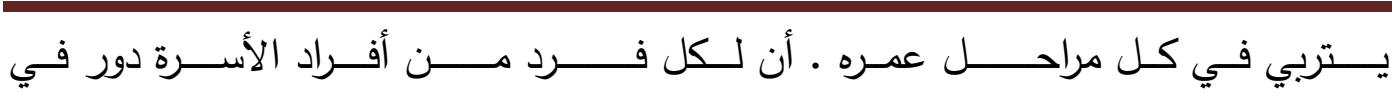
التربية للطفل من الوالدة التي يكون على عاتقها التربية الأولى ثم الوالد . دور الأم

تعد المدرسـة الأولى في حيـاة الطفل والمراهق، لمـا لها مـن دور عظيم في إعداد

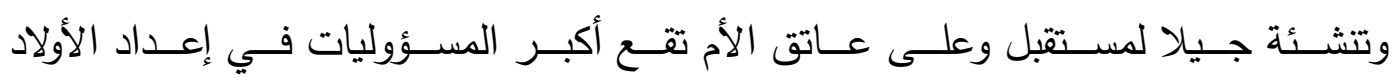
وتوجيه8م في نواحي عدة منها :

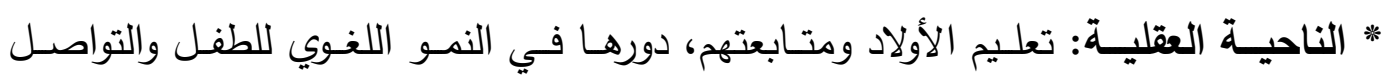
الكلامي عن طريق تتبيه حواس الطفل واستجاباته للمثيرات الاجتماعية .

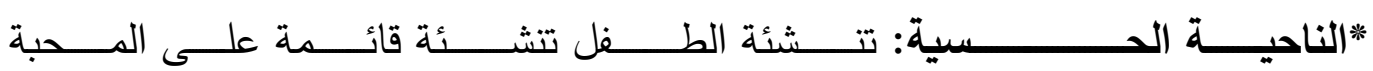

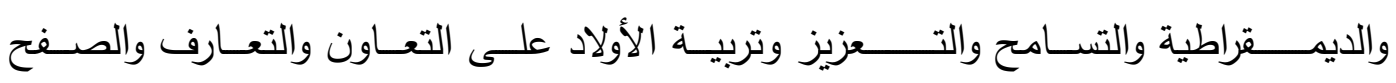
والجرأة في حسدود اللياقة *الناحيـة الاجتماعيـة : تعـــــــم الأم أطفالهـا وتوعيتهم باختيـار الاصـدقاء والابتعـاد

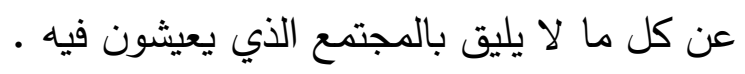

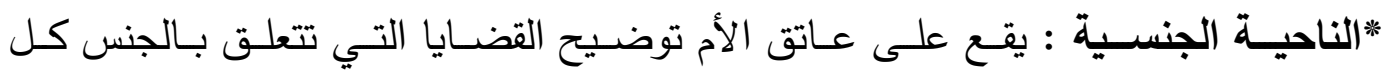

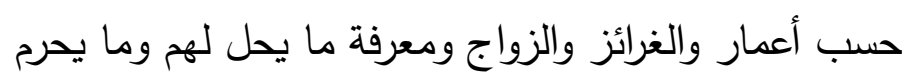

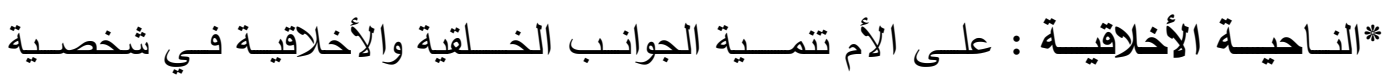

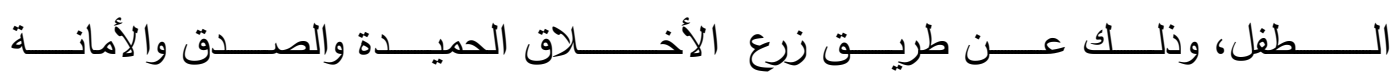
والاستقامة....الخ

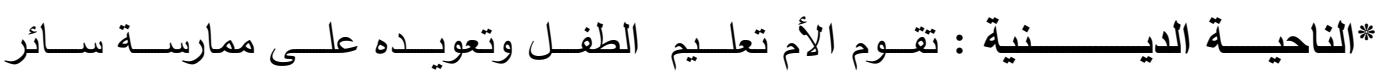

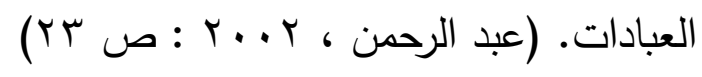
دور الأب

نظـراً لكـون الأب هـو الـذي يعـول الأسـرة اقتصـاديا ويمثلهـا فـي المجتــع وهـو

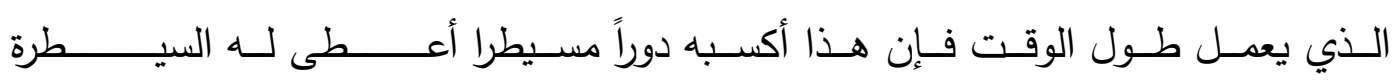

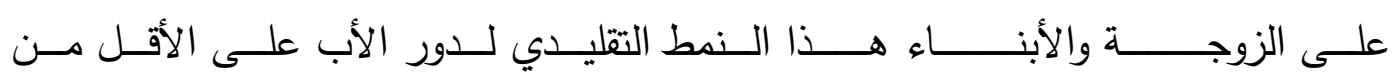

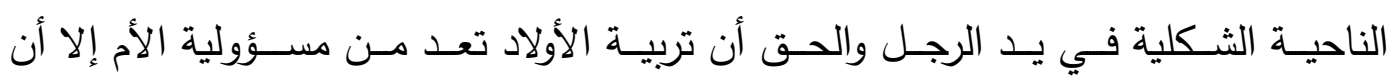

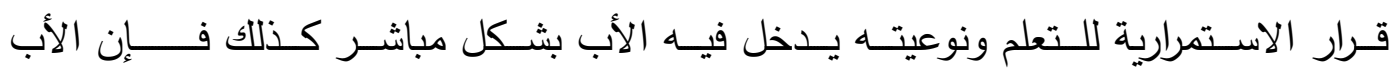

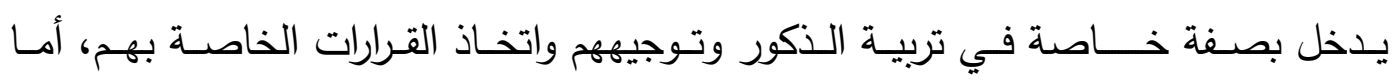

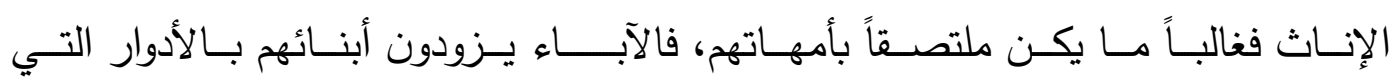

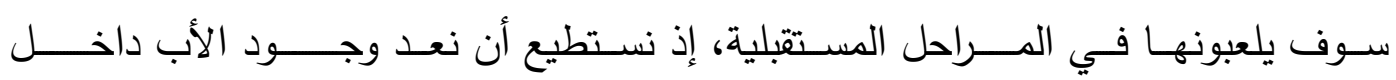

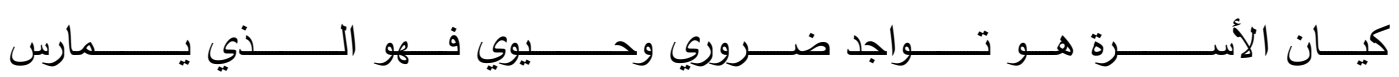




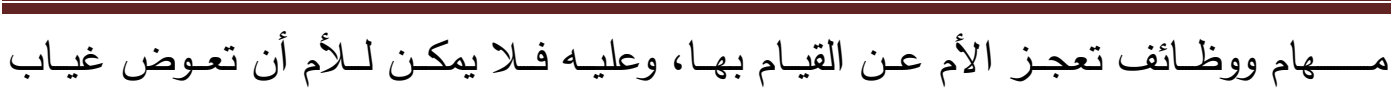

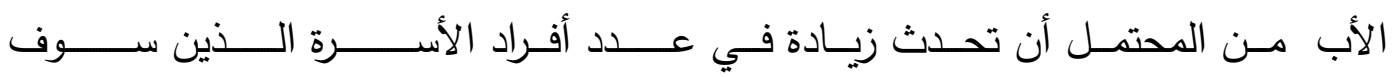

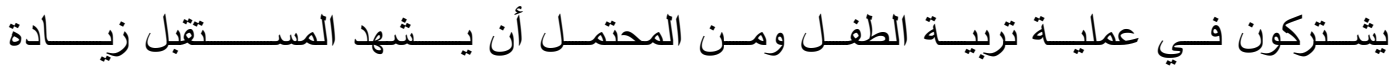

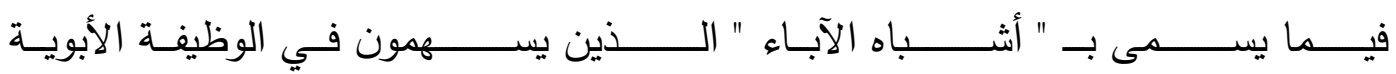

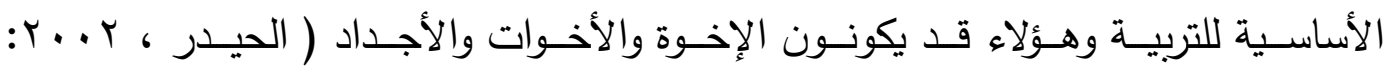
ص ص دور الأخوة

إن التفاعـل بـين الإخـوة يمهـد للانتقــال إلـى التفاعـل مــع الرفــاق، فالتـــافس بـين

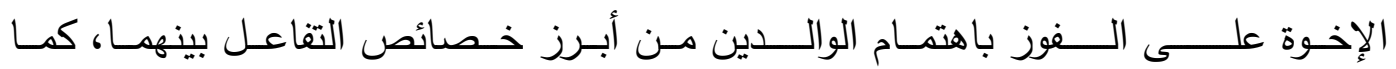

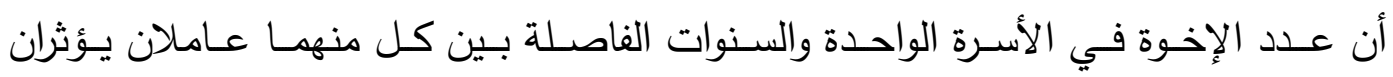
على نوعية التفاعل فيما بينهم، فالطفل يقلد أخاه . وفي دراسـة لـ فكثور victor civilly

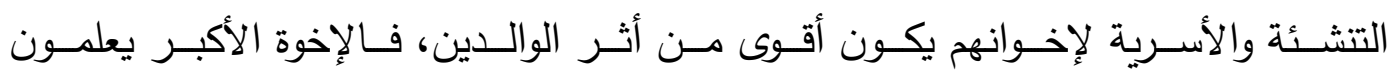

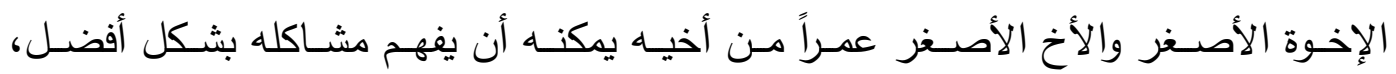

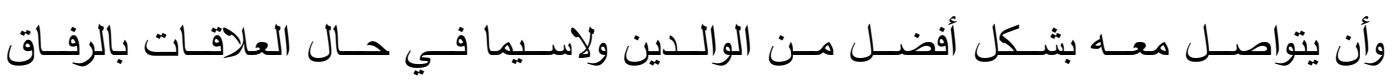

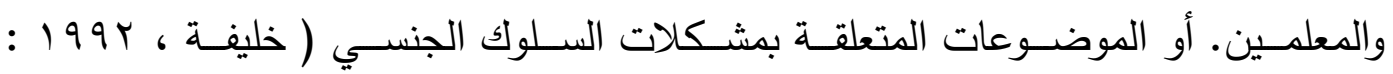

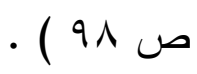

\section{أذن ما هي العوامل المؤثرة في الدور التربوي للأسرة}

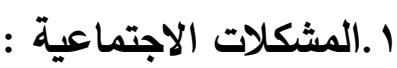

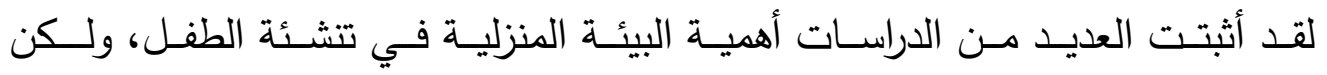

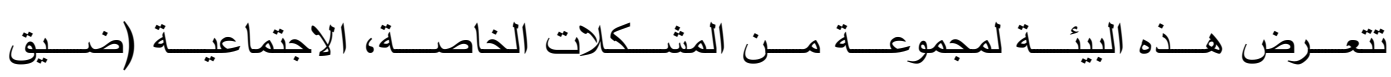

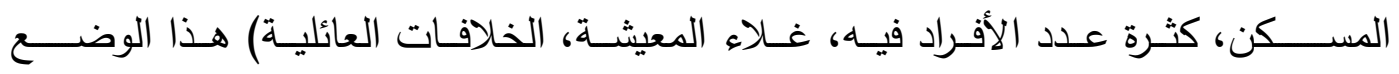

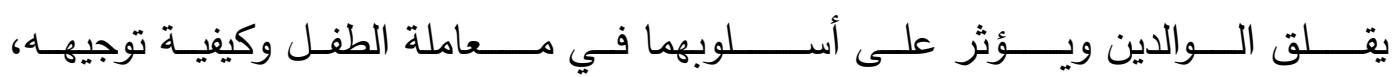

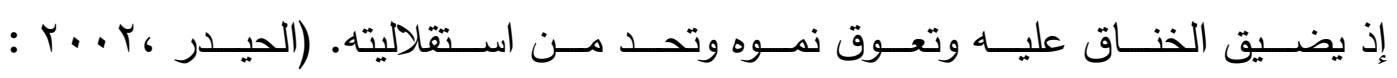
ص090) ب اتجاهات الوالداين

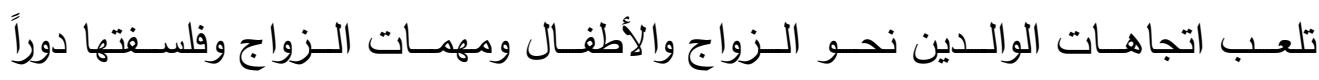

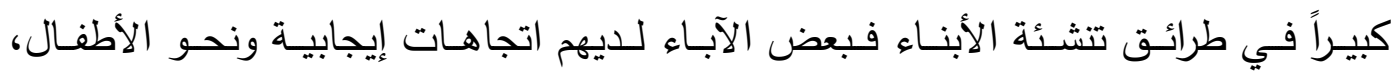

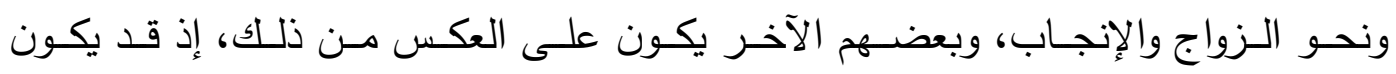

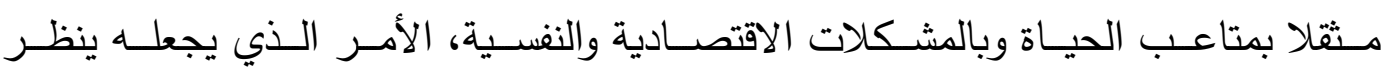




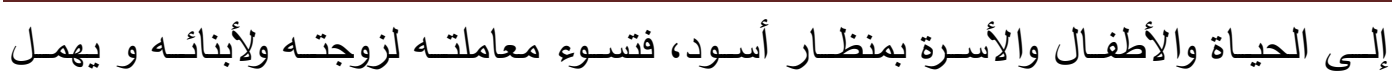

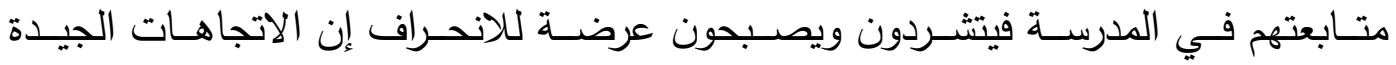

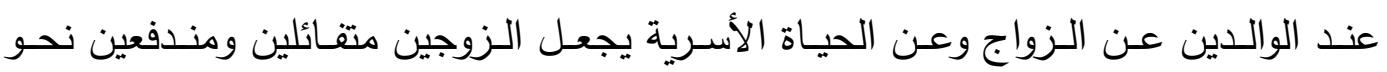

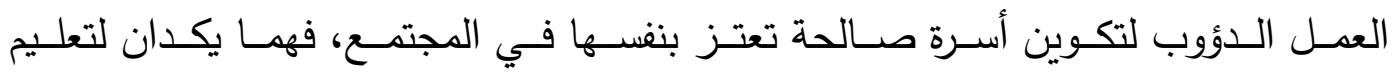

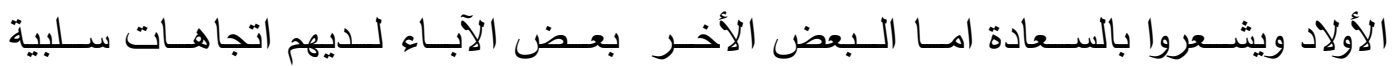

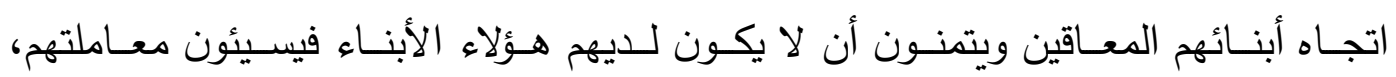

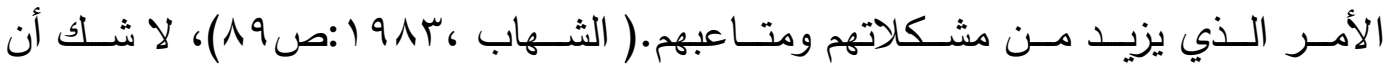

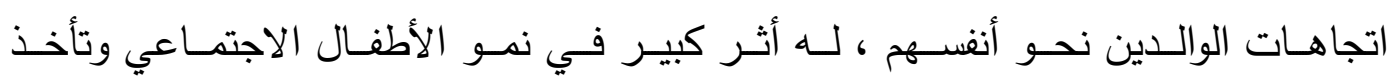

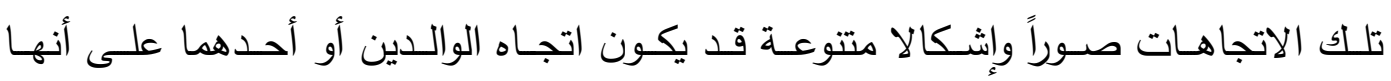

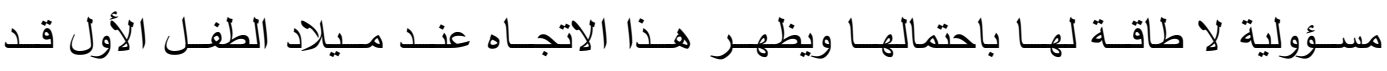

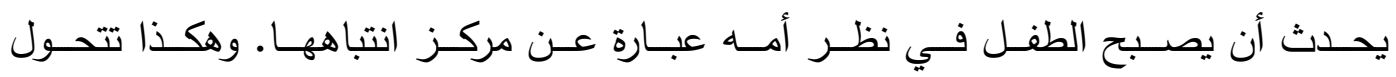

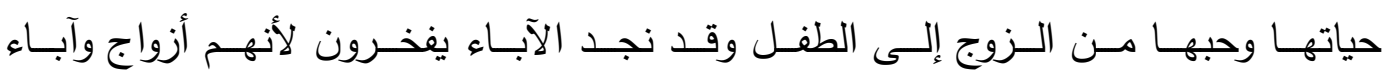

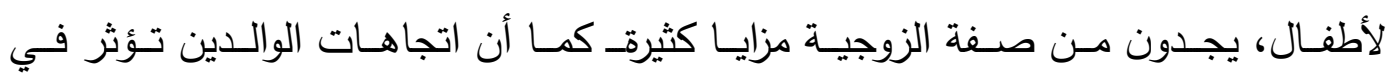

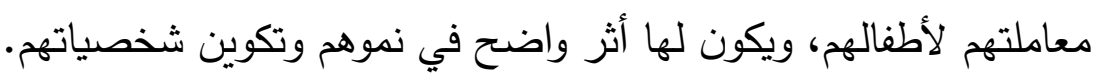

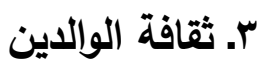

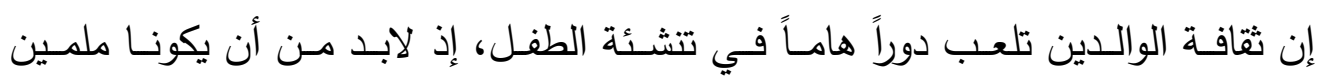

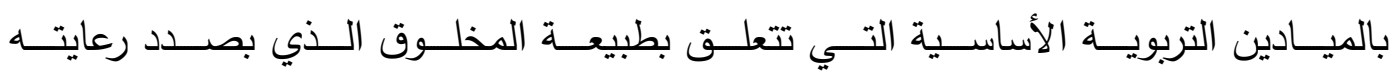

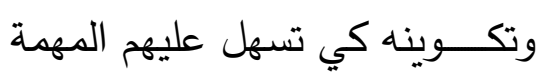

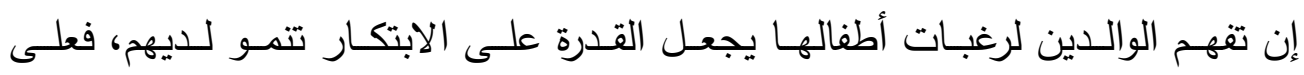

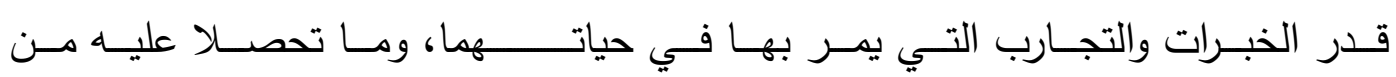

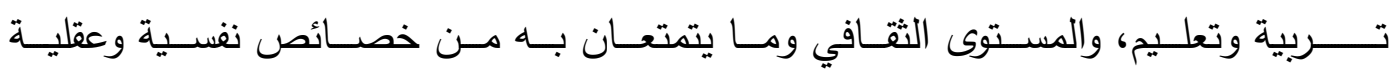

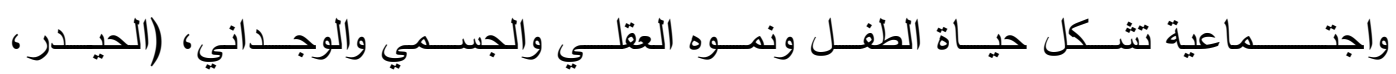

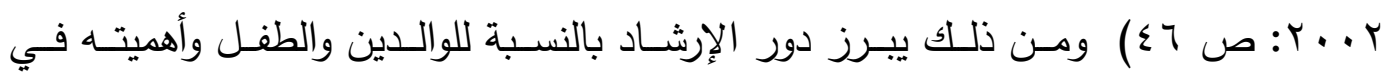

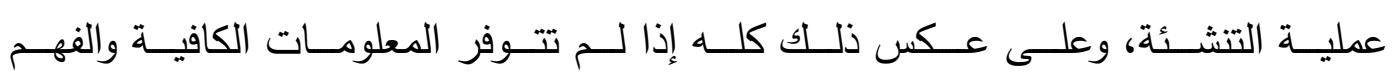

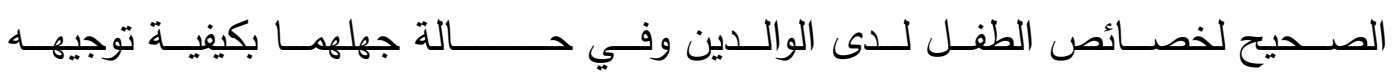

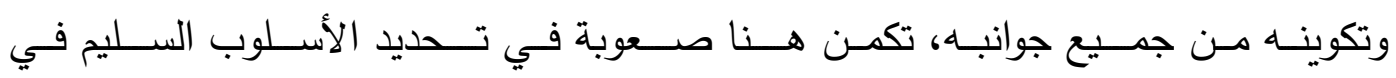
عملية التوجيه والإششاد. ع. الاستقرار الأسري: الإنئ

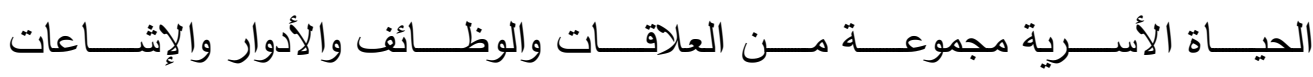

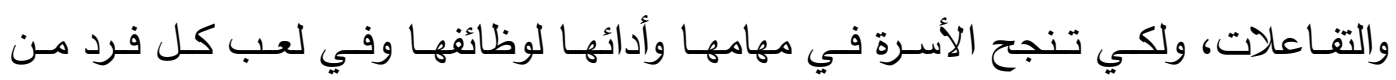




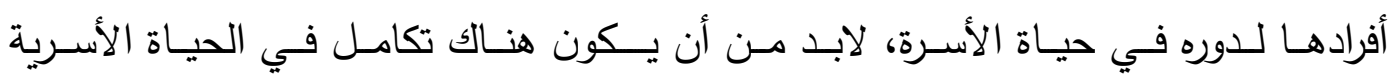

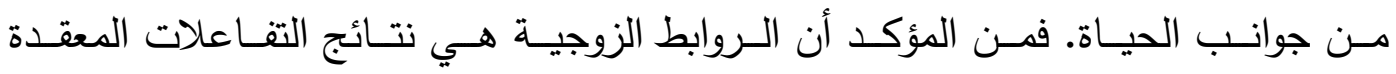

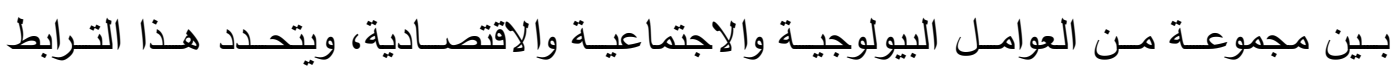

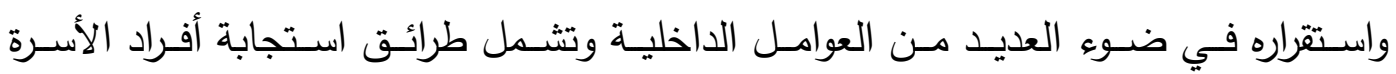

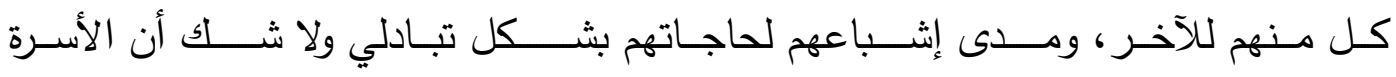

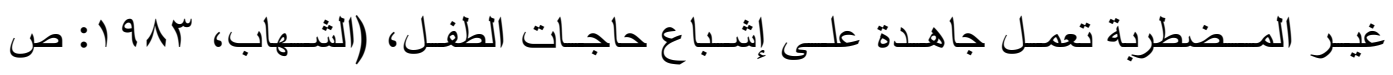

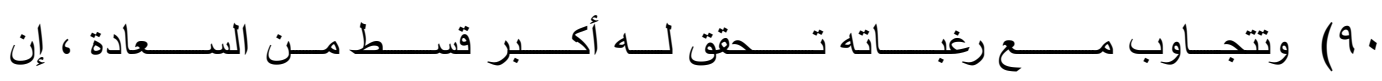

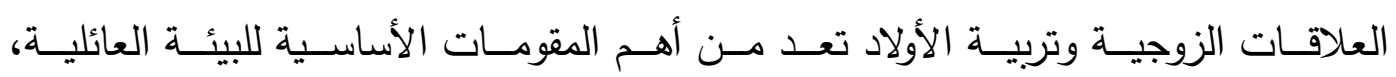

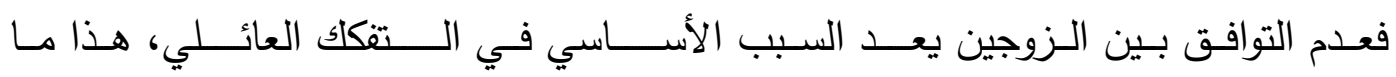

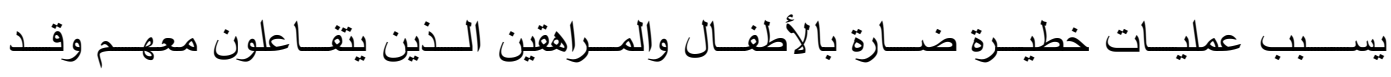
يصبحون نتيجة ذلك أحداث جانحين.

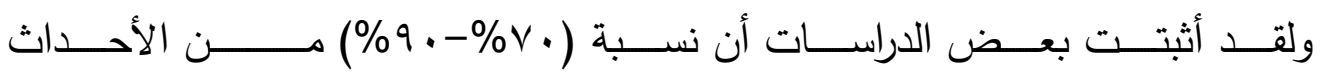

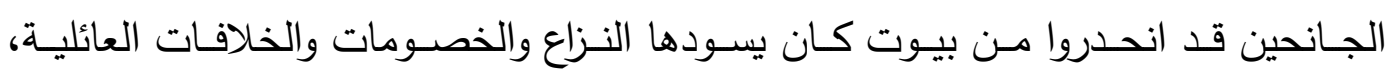

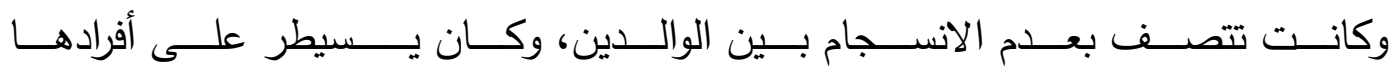

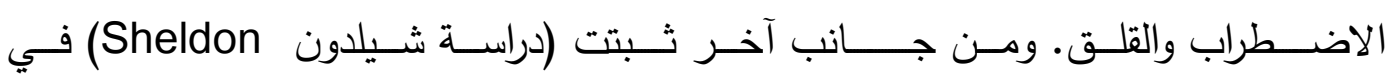

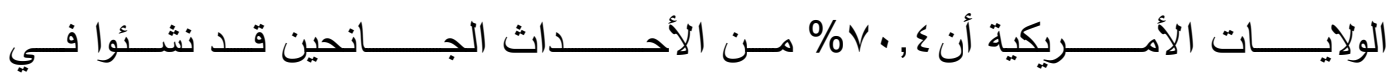

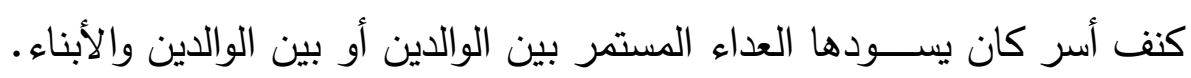

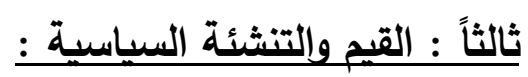

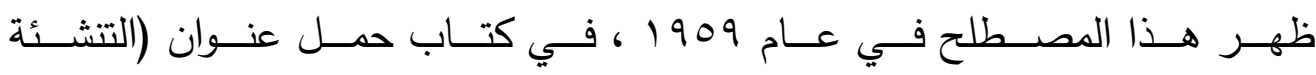

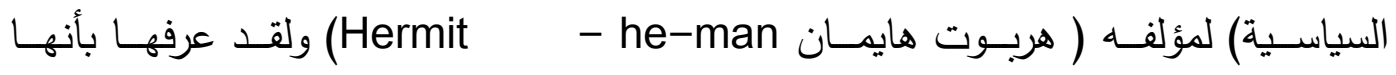

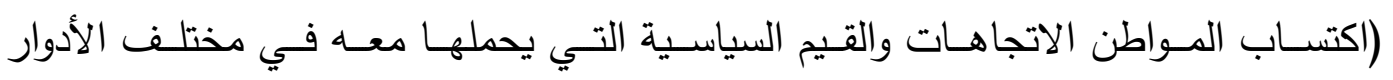

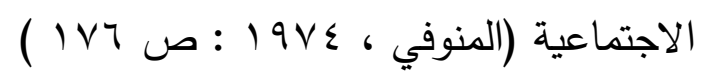

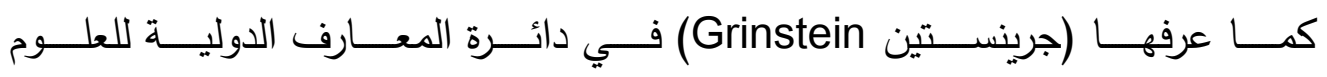

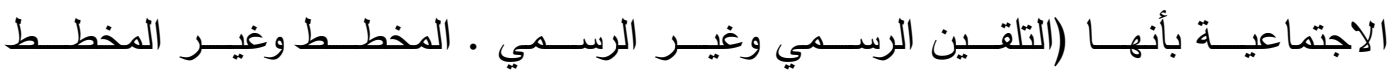

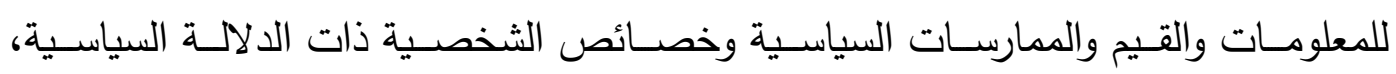

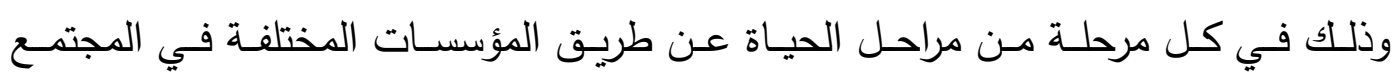

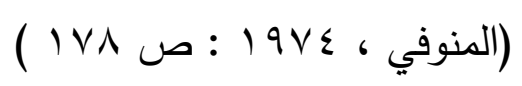

أمـا ومـيض فقد عرفها بانها : (محاولـة لتدريب النـاس على أن يفعلوا مـا يتطلبـه

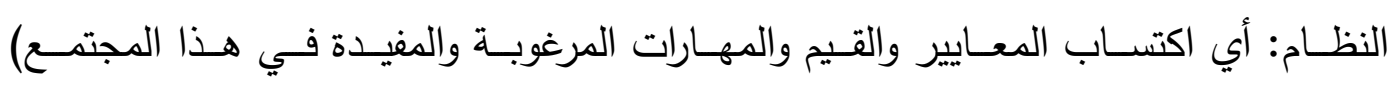

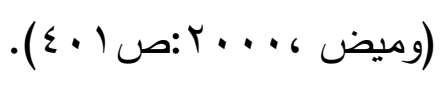




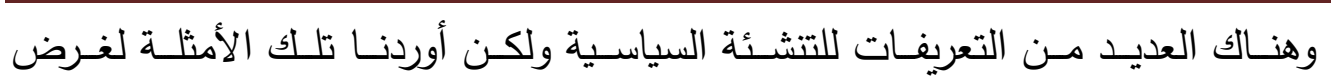

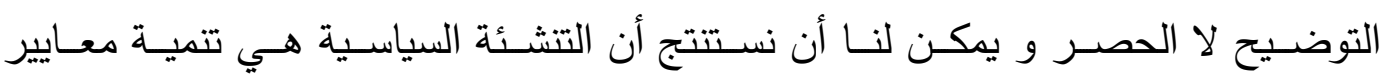

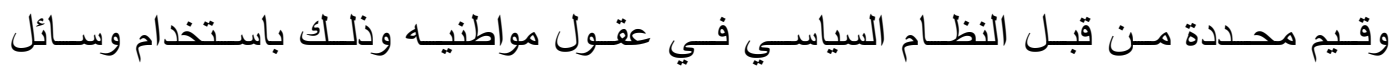

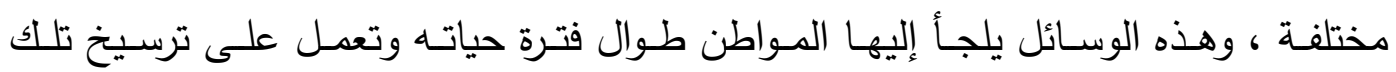
القيم والمعـايير حتى يتقبـل عمل النظـام مـن جهـة، ويستمر النظـام بالبقـاء والاسـتمرار

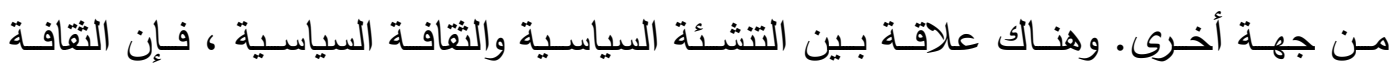

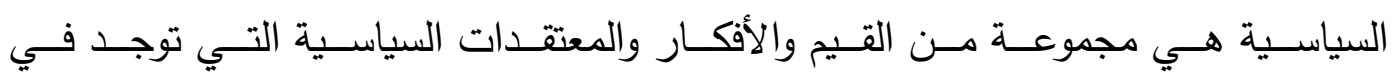

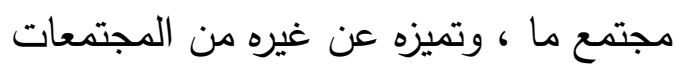

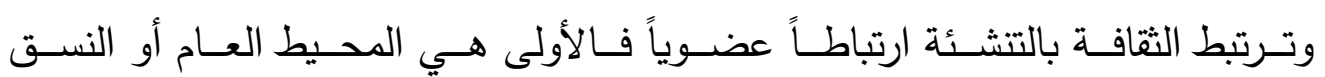

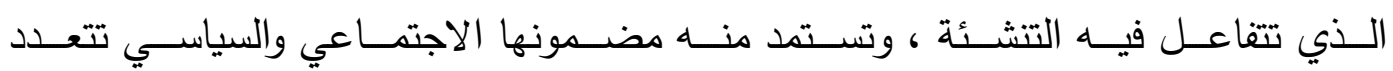
الثقافـات السياسـية فـي المجتمعـات ، فبعضـهـا يقـوم علـى المشـاركة وبعضــهـا الأخـر

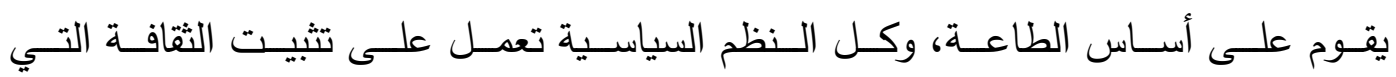

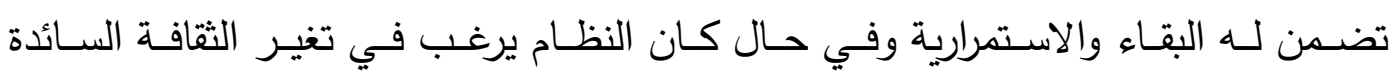
فبطبيعة الحال سيعمد إلى تغير التنشئة السياسية التي غذت تلك الثقافة.

\section{أهمية التنشئة السياسية:}

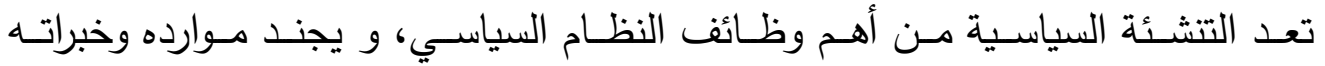

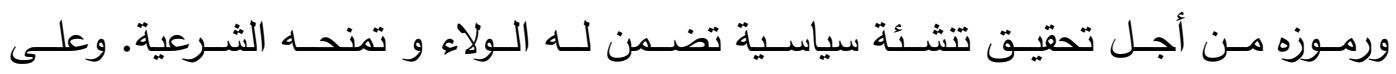

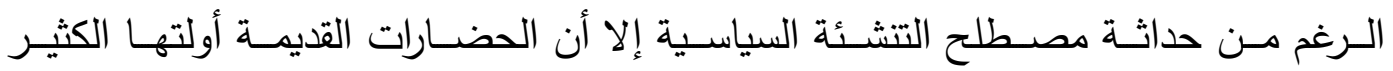

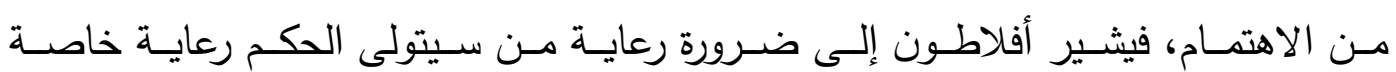

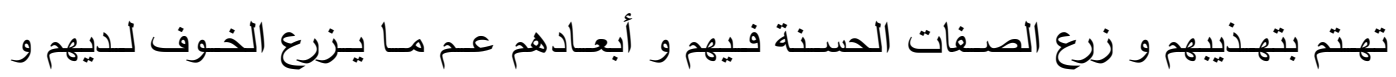

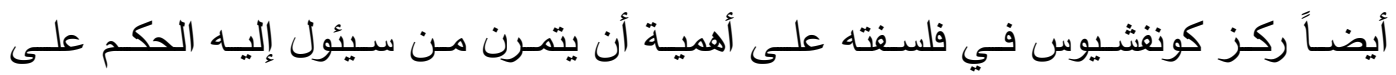

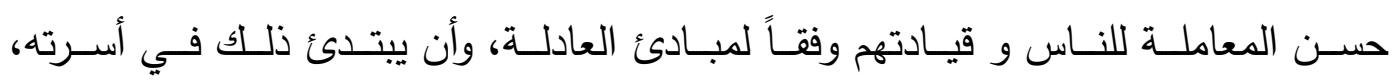
فإن نجح في ذلك ببيته استطاع أن يقود المتمع ويحقق العدالة والطمأنينة للجميع.

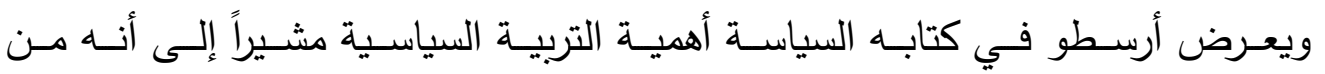

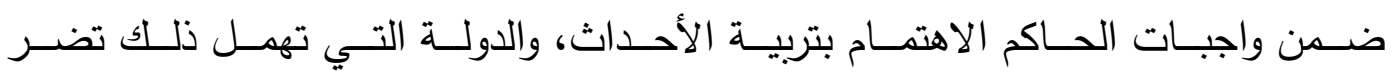

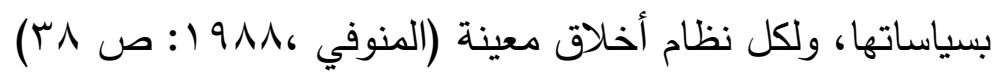

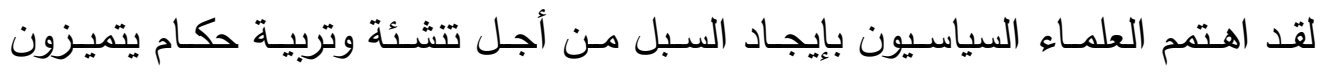

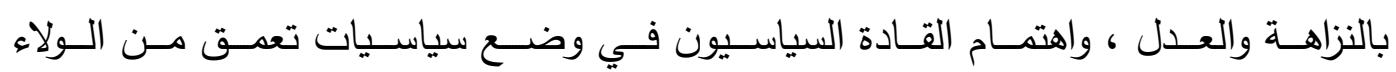

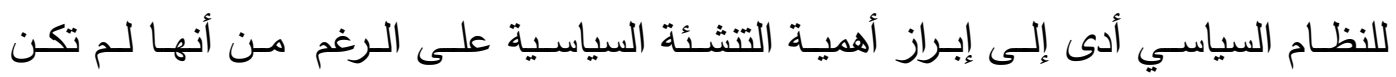

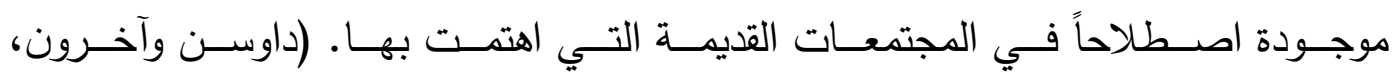




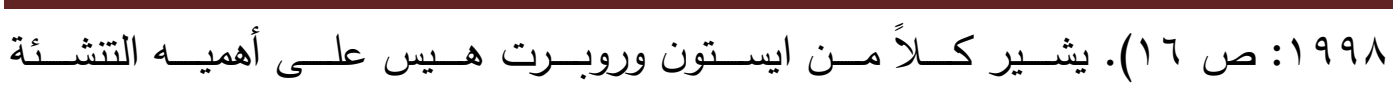

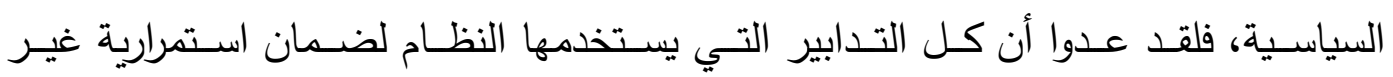

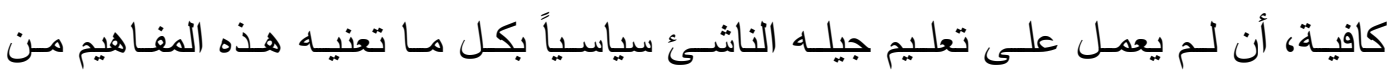

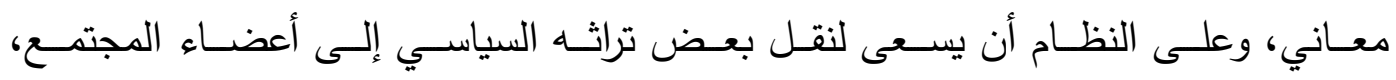

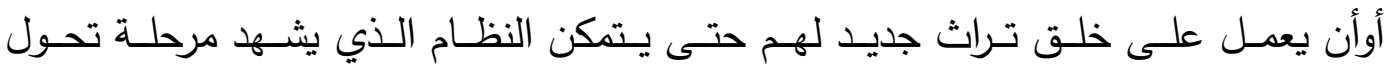

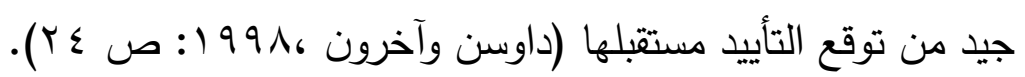

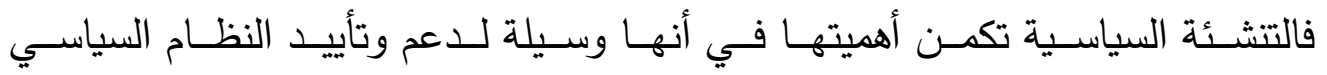

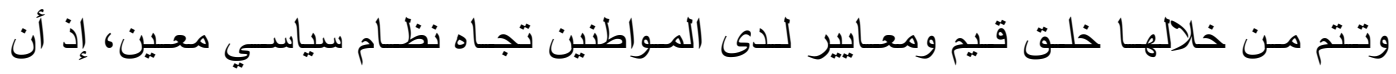

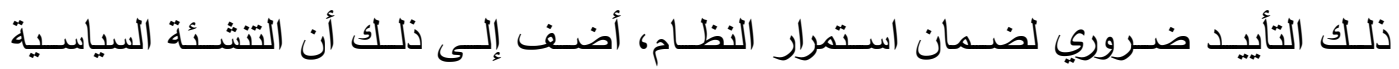

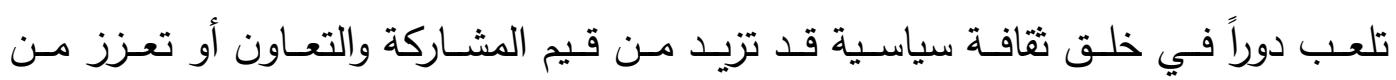

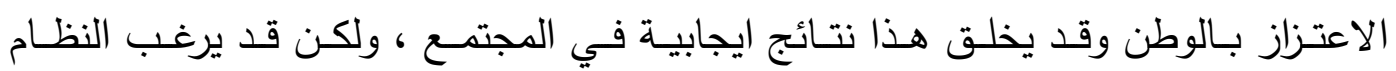

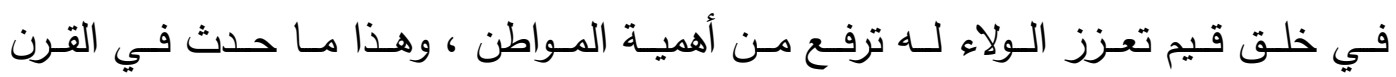

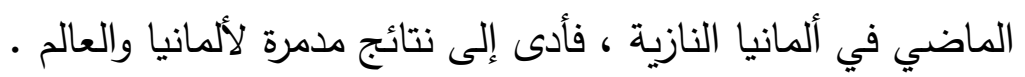

أدوات التنشئة السياسية فياتية

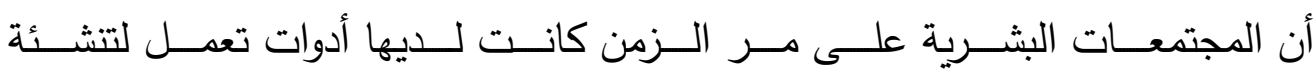

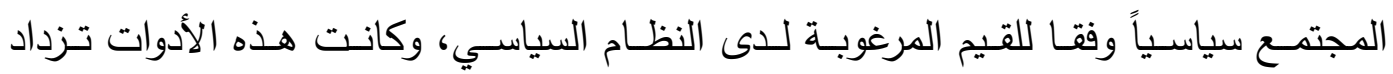
أهميتها في بعض الفترات وتقل في أحيانا أخرى.

أدوات التنشئة السياسية:

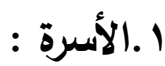

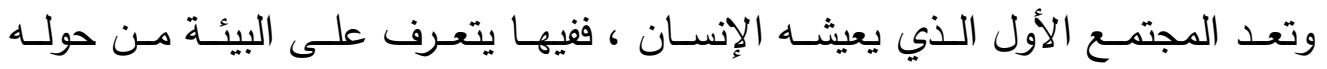

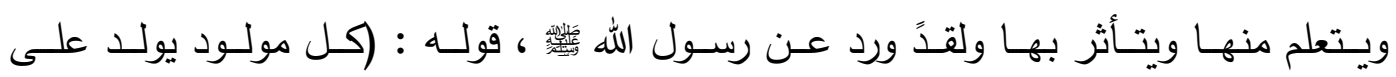

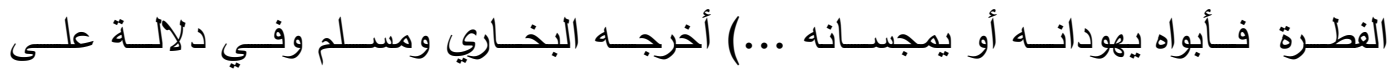

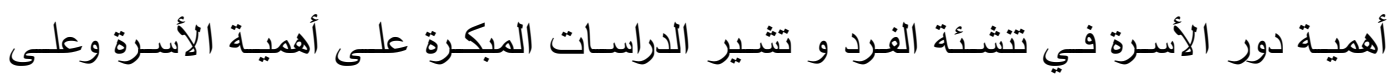

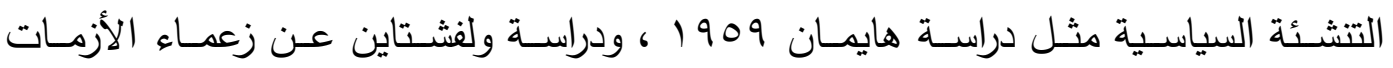

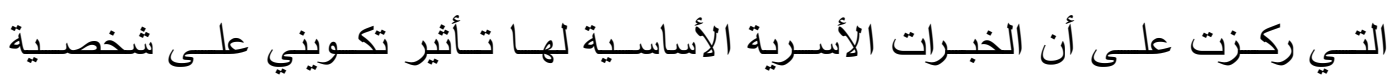

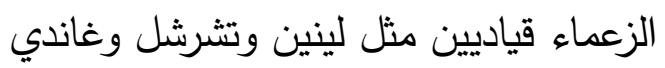
r. المدرسة:

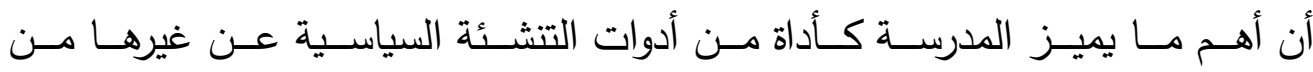

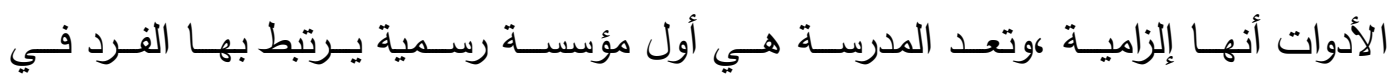

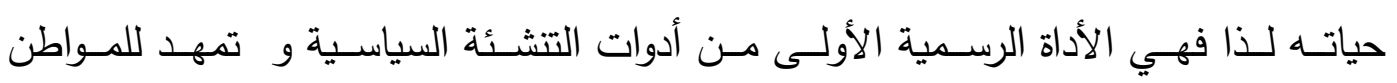




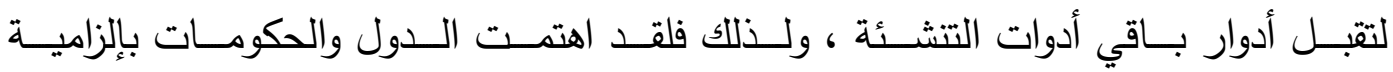

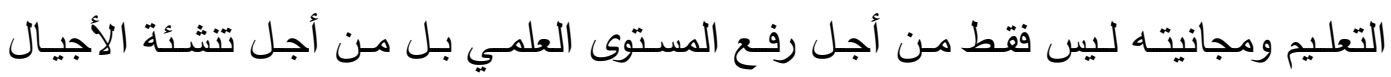

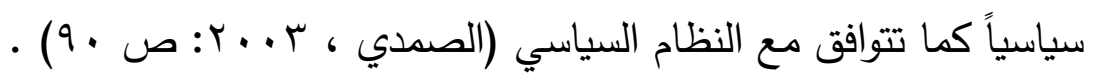

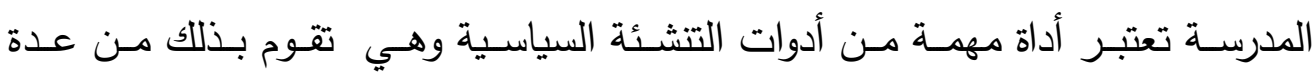

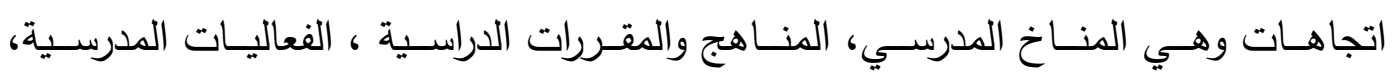

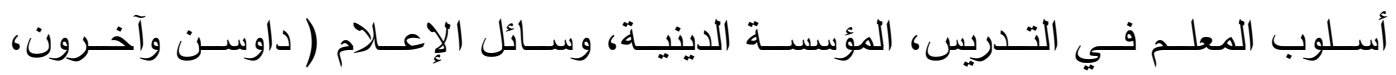
•

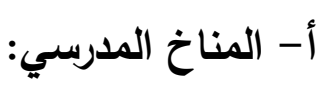
أن المدرســة هـي المؤسسـة الرسـمية الأولـى التـي يلتحـق بهـا الفـرد ، فأنـهـ يتـأثر

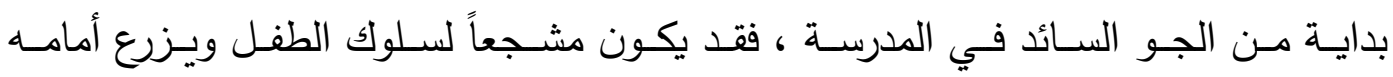

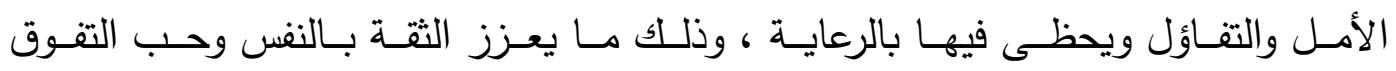

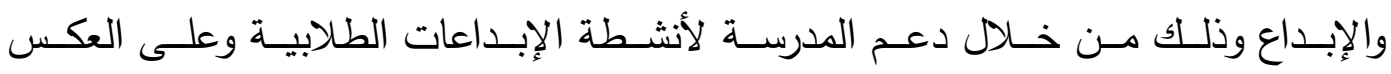

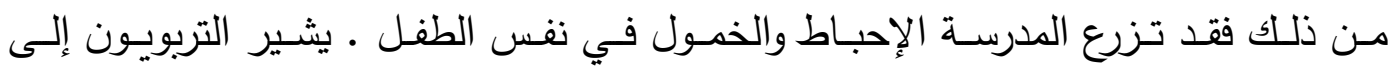
تصنيف المدرس حول ثلاثة أنماط :

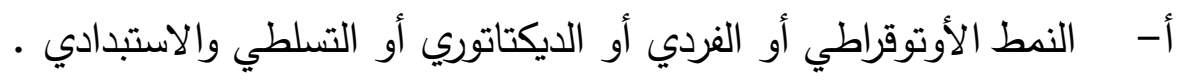

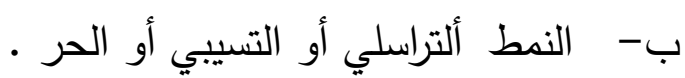

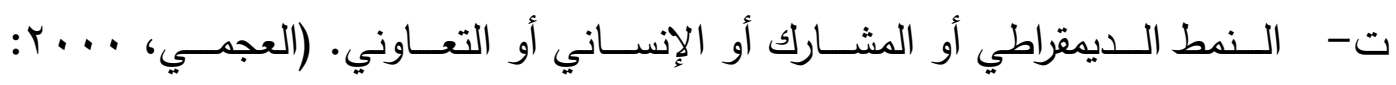
. $(\varepsilon \cdot \omega$

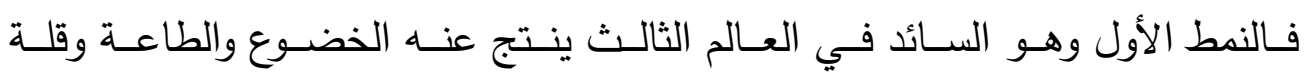

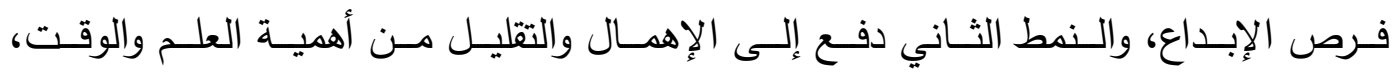

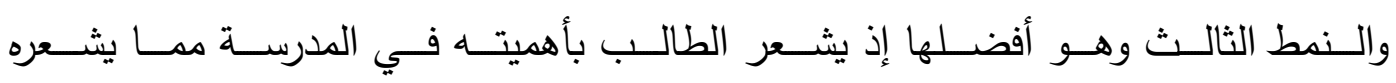
بالمسؤولية .

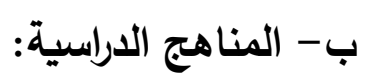

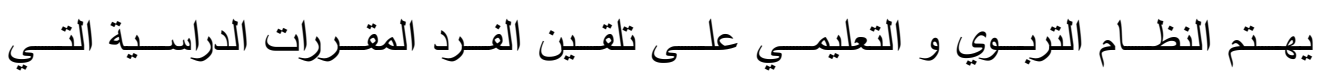

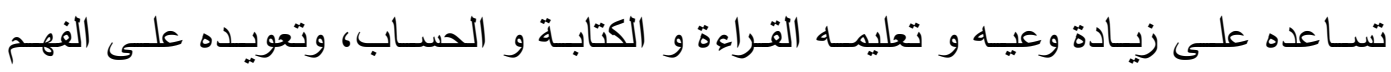

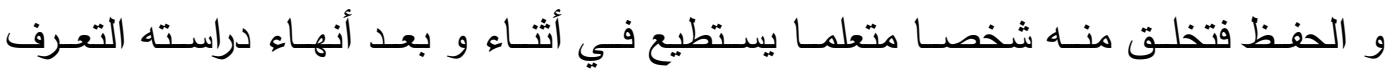

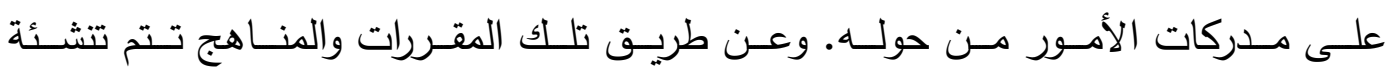

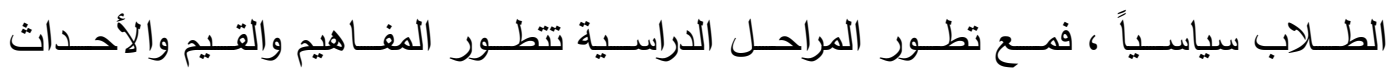

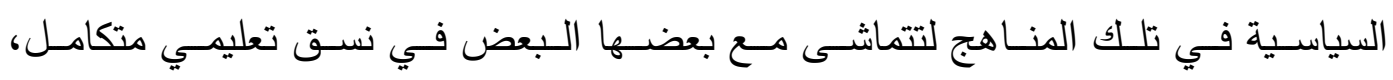
ولتواكب النمو العقلي والمعرفي للطالب مساعدة في ذلك. 
وترتكـز تتشـئة الطـلاب سياسـياً على مقـررات معينـة أكثر مـن غيرهـا، فــثلاً

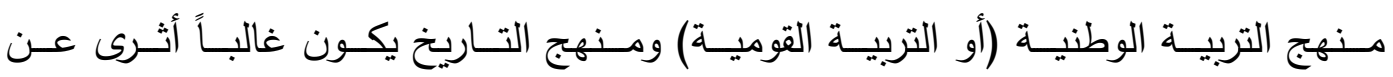

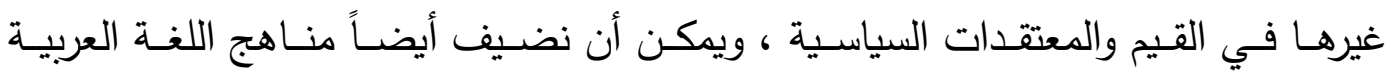

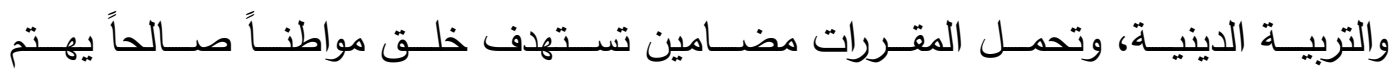

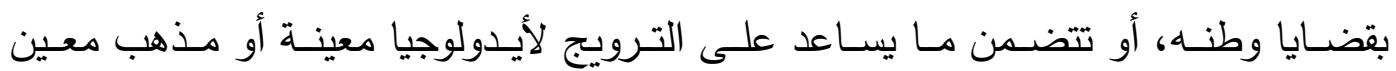
و يخلع الثرعية على النظام السياسي، وقد تجمع المقررات بين النوعين.

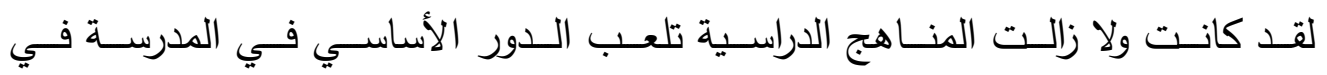

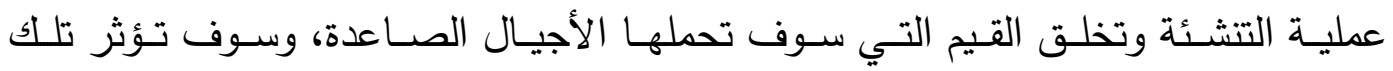

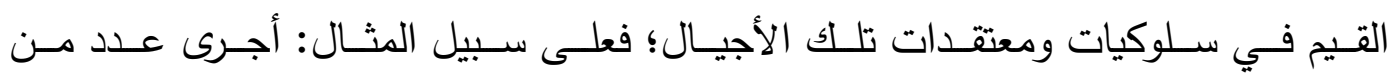

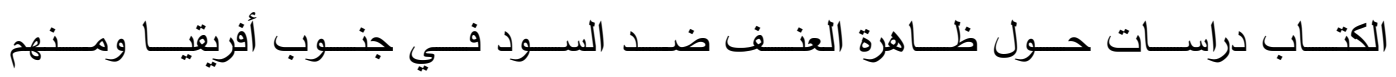

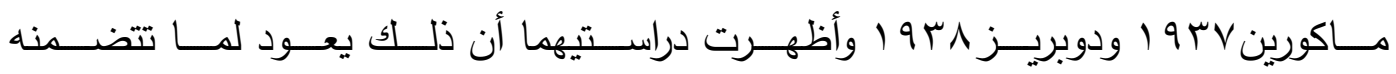

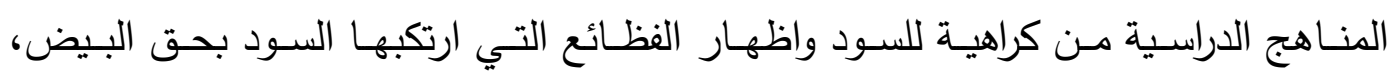

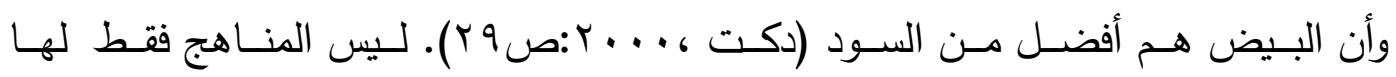

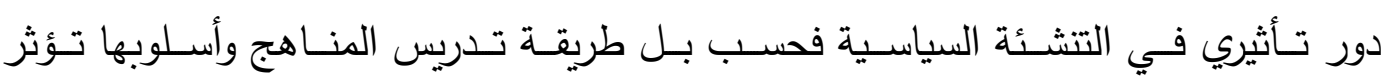

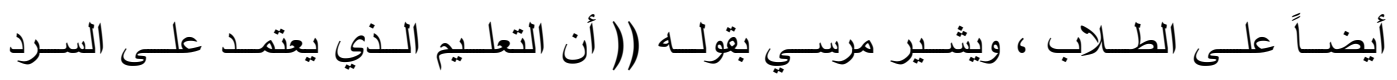

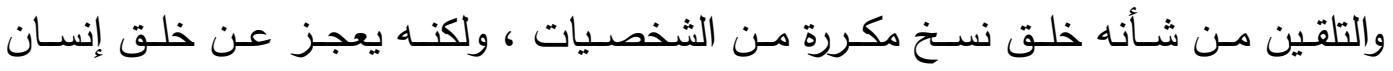

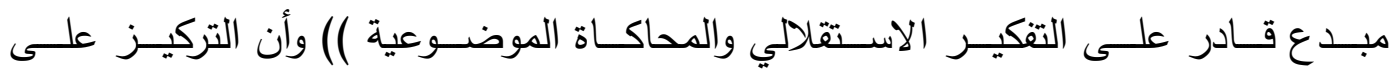

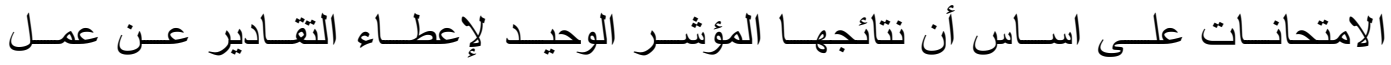

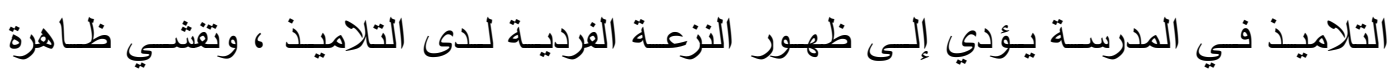

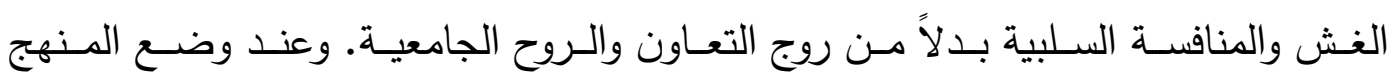

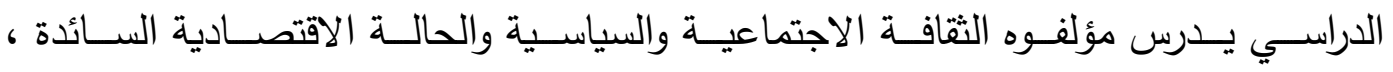

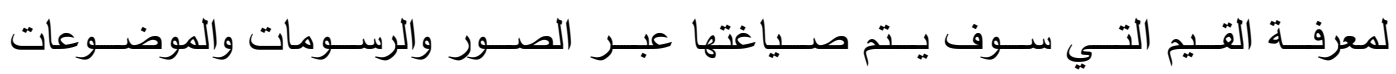

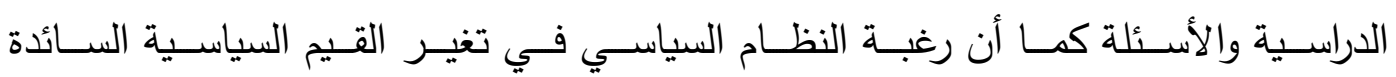

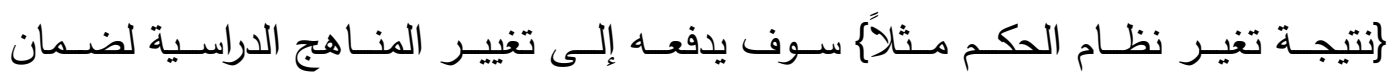

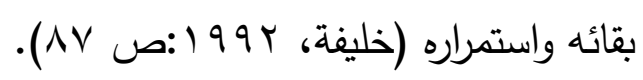

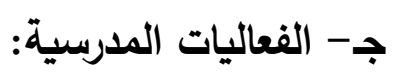

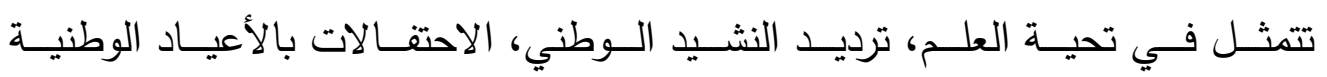

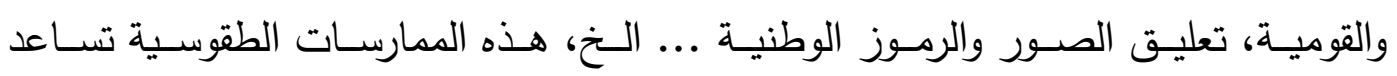

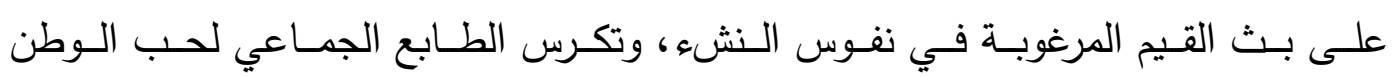
والانتماء إليه لكونها تمارس بطريقة جماعية في الأغلب الأعم. 


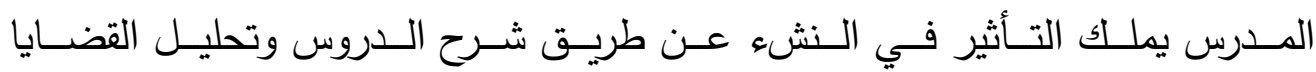

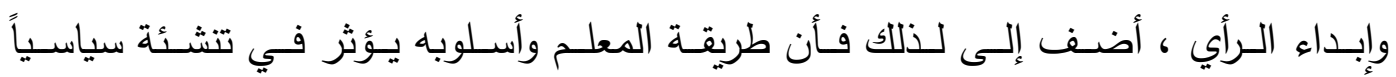

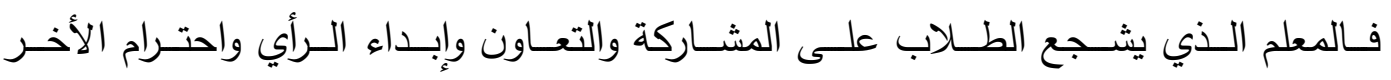

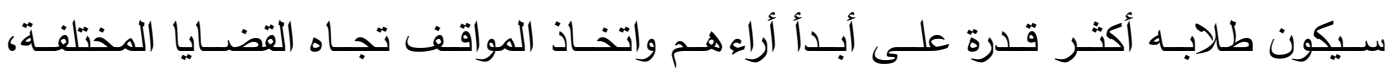

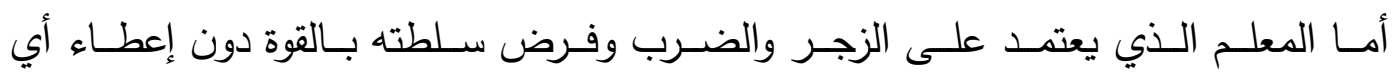
فرصة لطلابه تعبير عن أراءهم سيكون طلابه أقل جرأه ويحملون شعوراً باللامبالاة. r- المؤسسة الدينية:

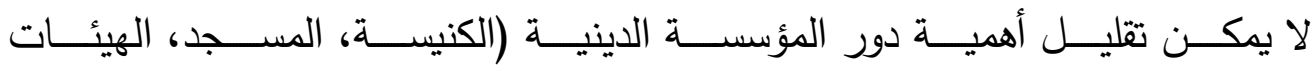

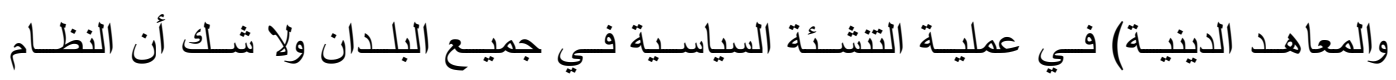

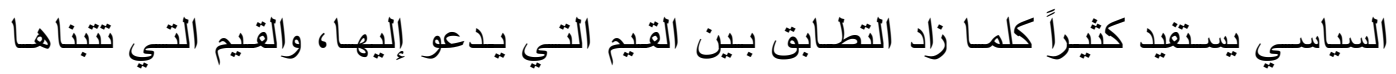

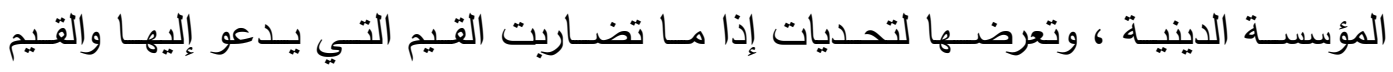

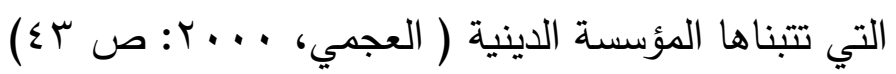

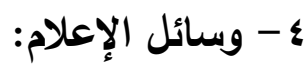

لقد أصـبحت وسـائل الإعـلام جزءءاً أساسـيا في البيـوت وانتقلت إلى وسـائل النقل

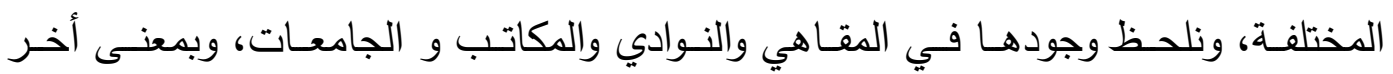

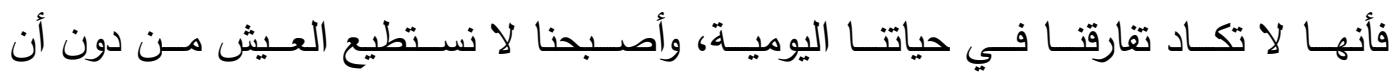

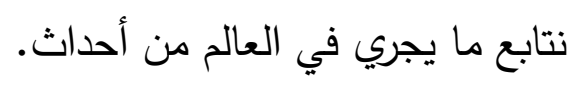

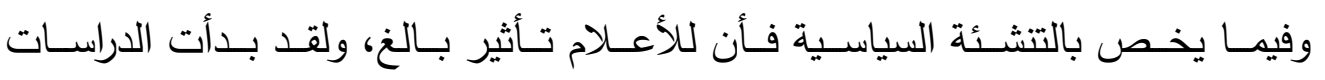

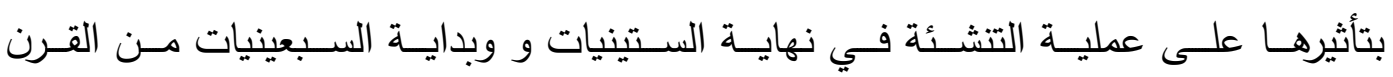

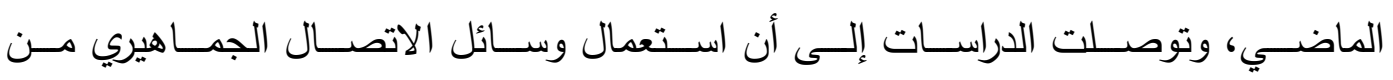

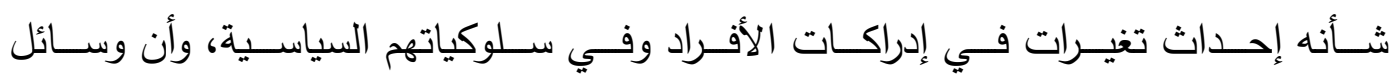
الاتصال تعد مصادر رئيسة في عملية التنشئة السياسية.

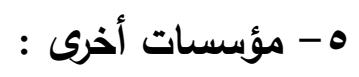

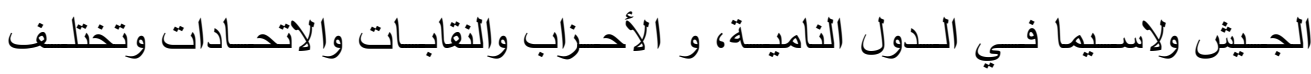

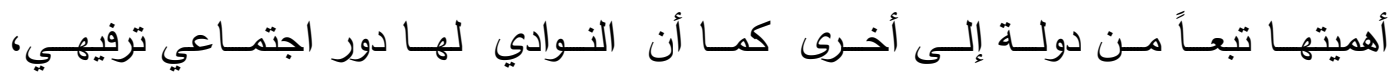

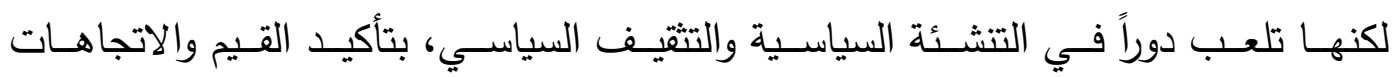
المأخوذة من الأسرة والدين ( دكت ، . . . ؟ ص • •؟). 


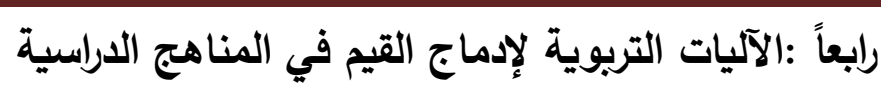

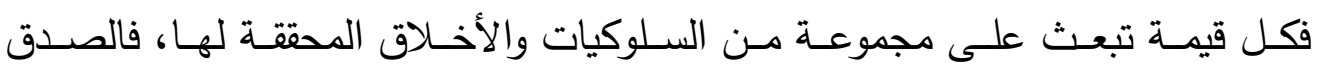

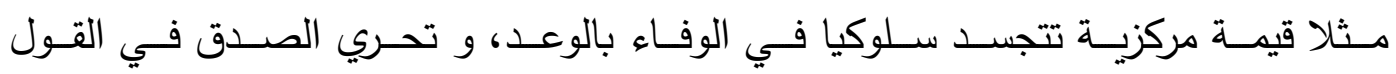

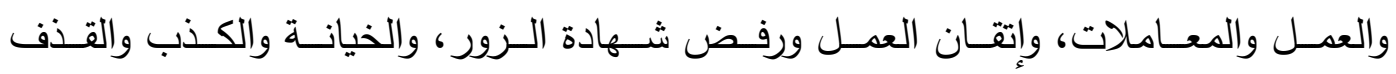

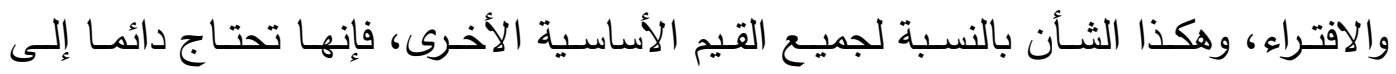

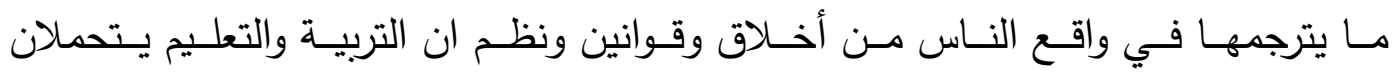

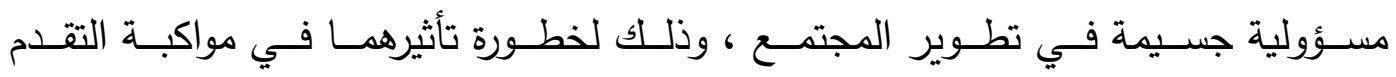

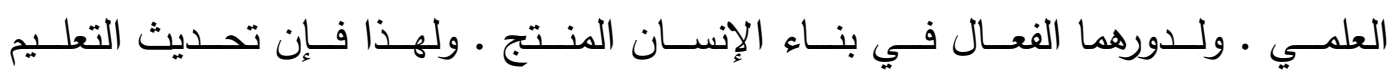

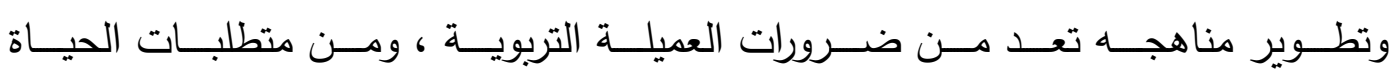

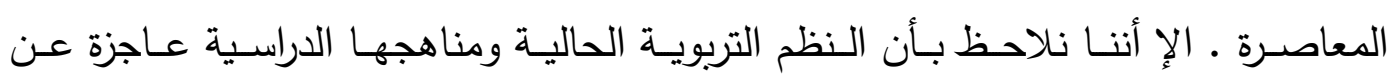

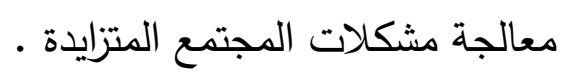

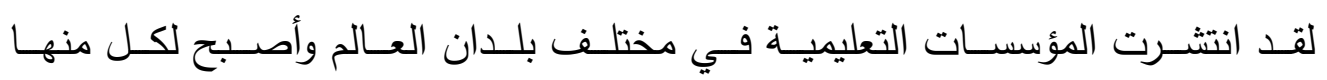

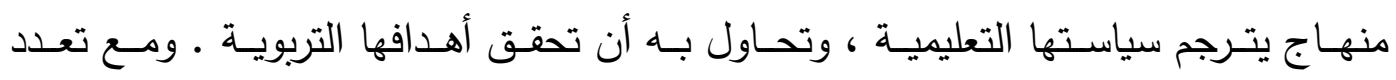

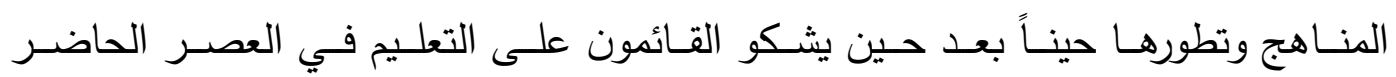

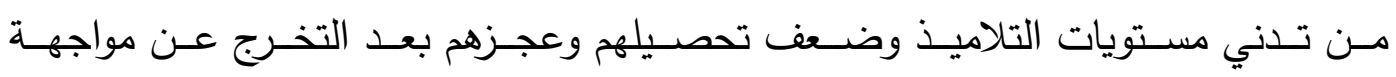

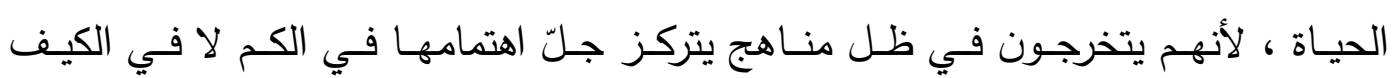

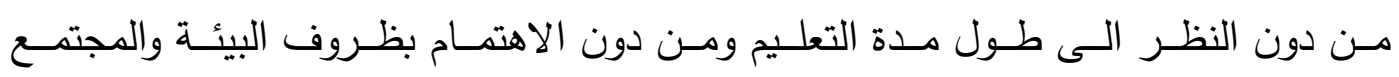

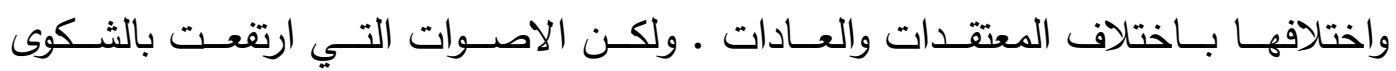

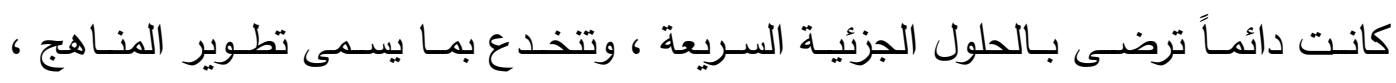

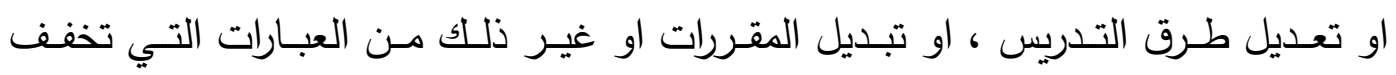

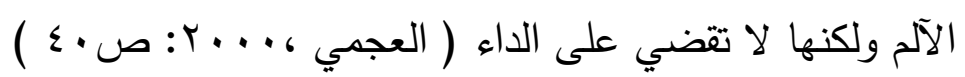

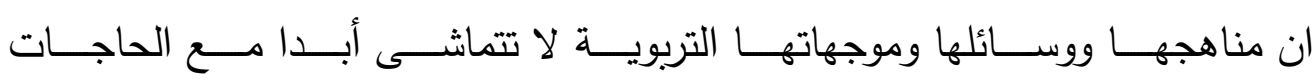

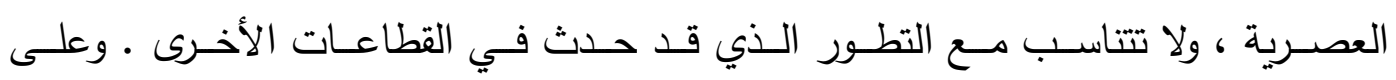

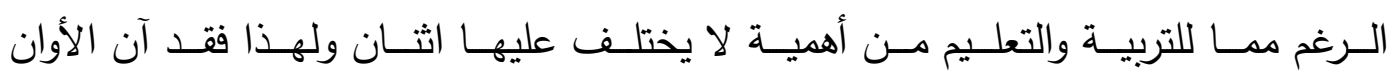

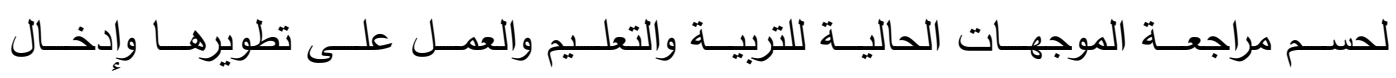

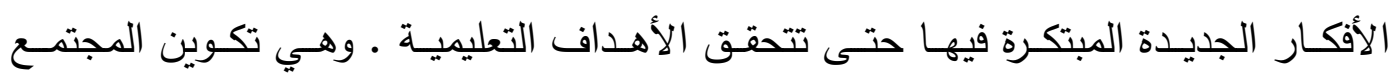

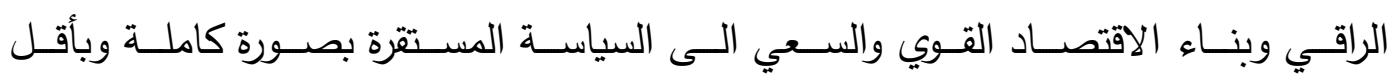
تكلفة

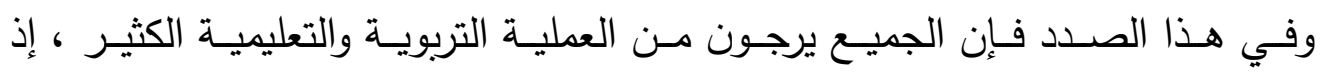
تقود المجتمع إلى تحقيق أهدافه العليا . 


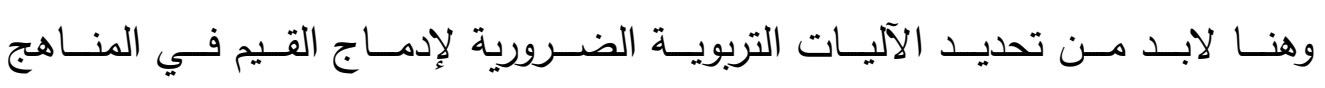
الدراسية وتكون كالاتي :

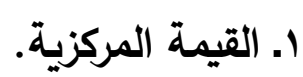

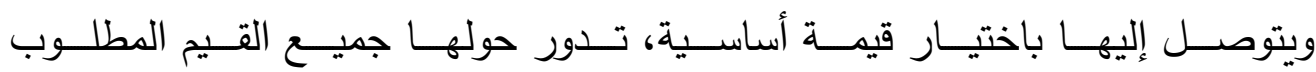

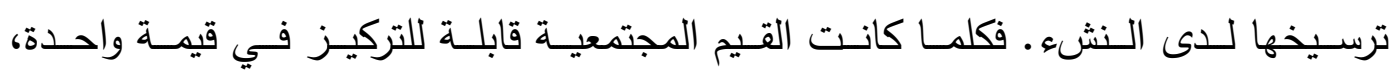

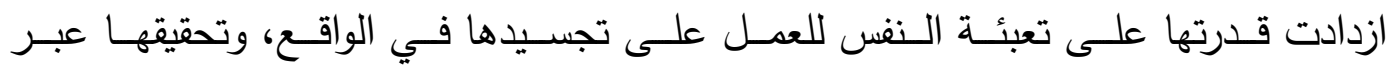

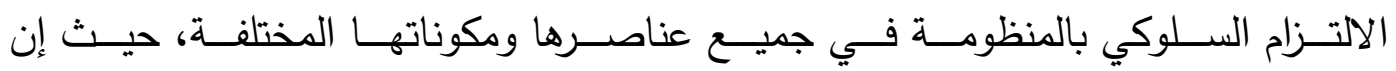

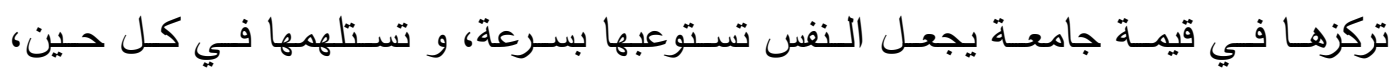

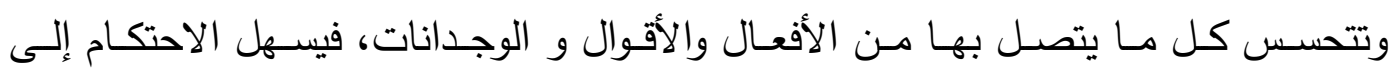

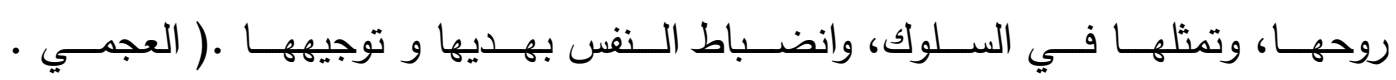
( $\leqslant \varepsilon$ : r...

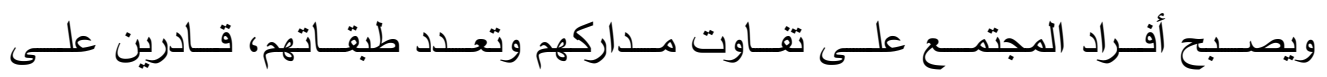

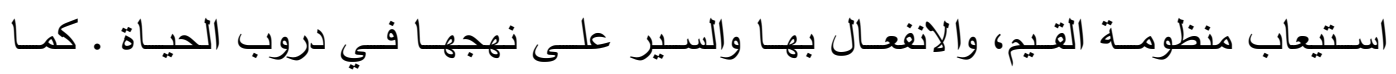

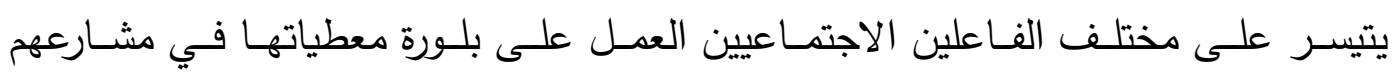

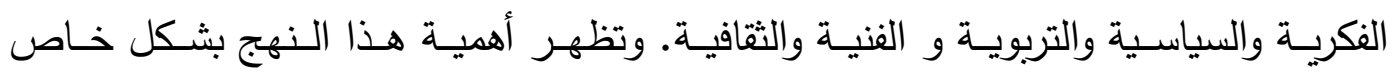

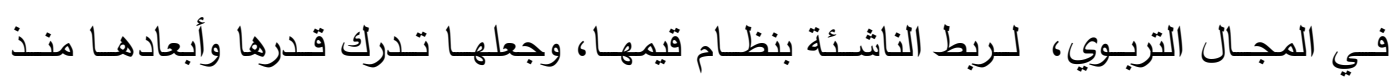
فجر طفولتها، لينمو في نفوسها حب تلك القيم والتشبع بها مع نمو جسمها وفكرها. r. القدرة التأطيرية للقيمة المركزية.

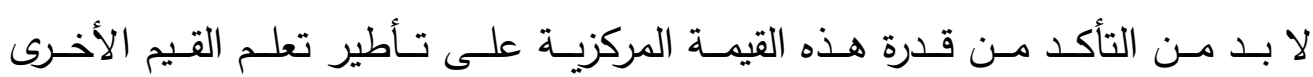

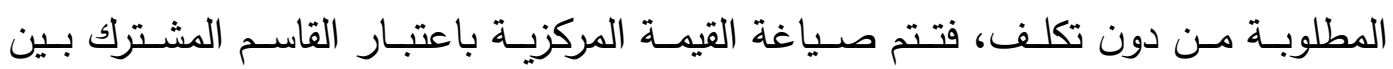

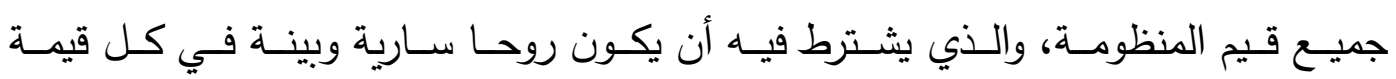
على حدة، من حيث كونها عنصرا ينتمي إلى منظومة معينة .

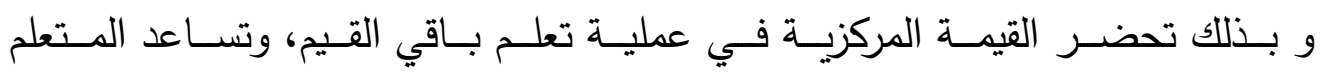

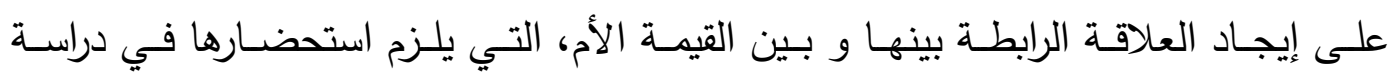

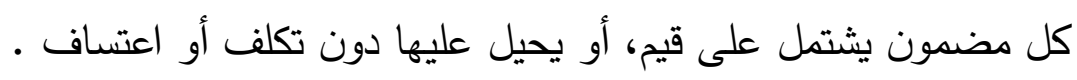
r. الإدماج في نشاط المتعلم.

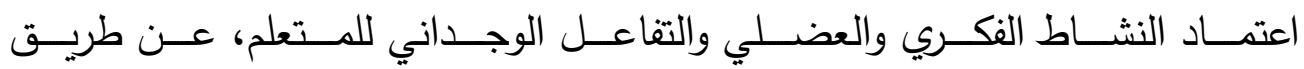
التدريس بمقاربة الكفايات، أساسا لترسيخ القيم في نفوس الناشئة .

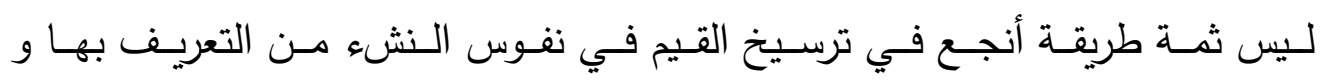

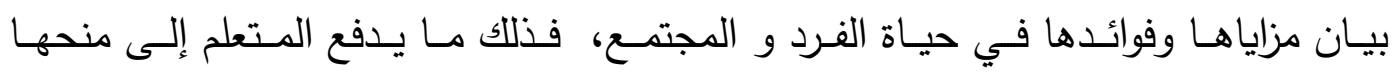




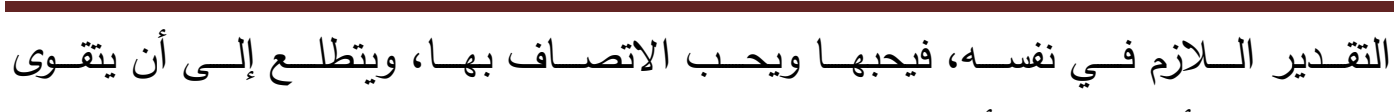

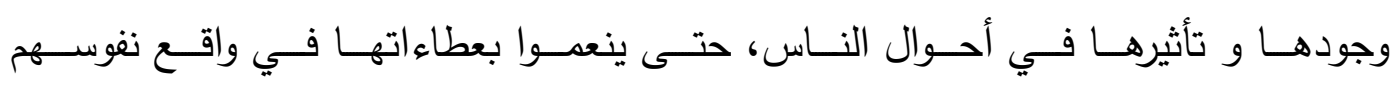

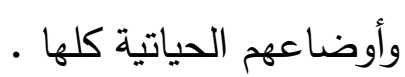

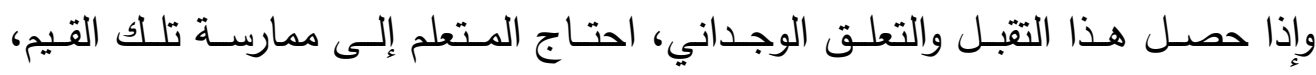

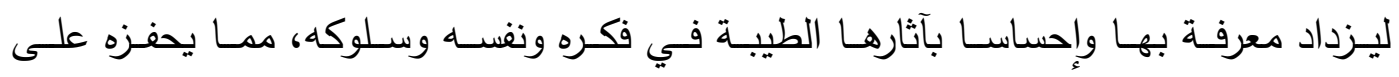

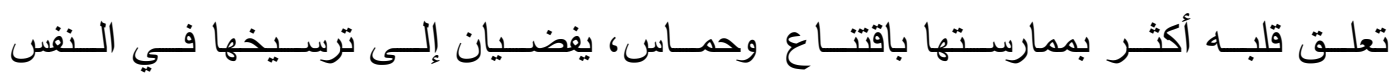
وتوجيهها للسلوك.

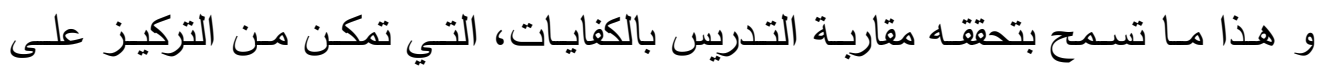

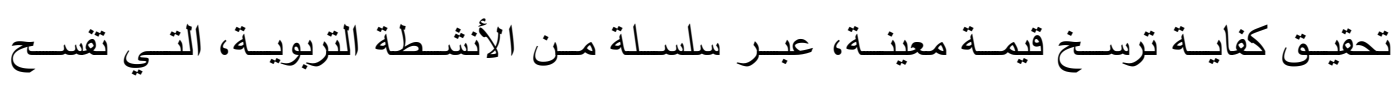

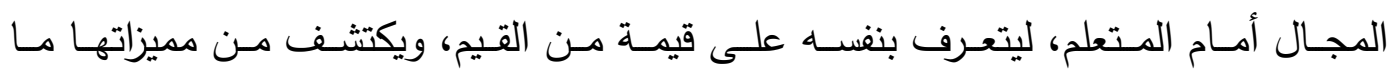

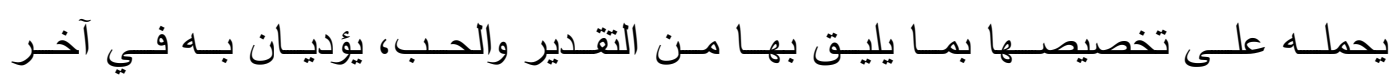

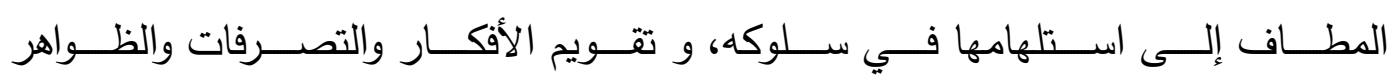
الاجتماعية، وتكوين مواقف شخصية إزاءها.

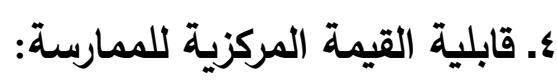

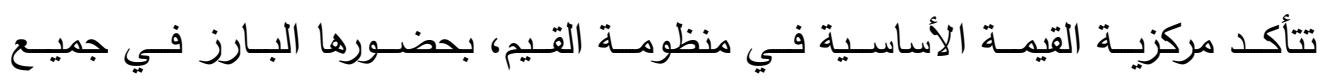

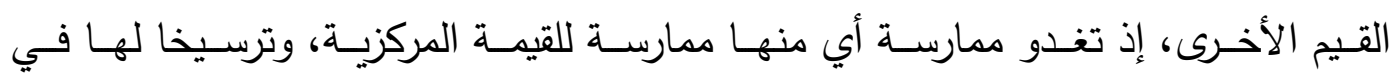
كيانات الأفراد والجماعات. فكـل قيمـة تتــرر ممارسـتها عبـر قيم أخـرى وبـوتيرة أكبـر فـي السـلوك اليـومي

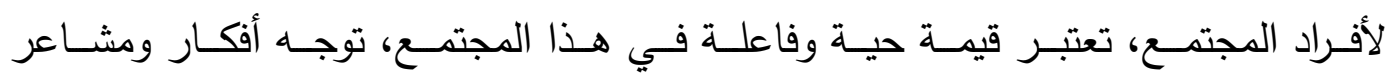

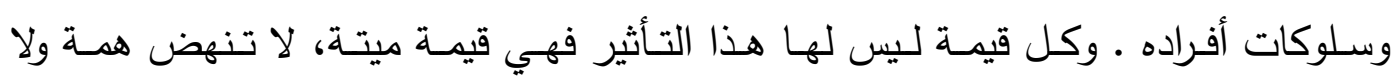
تنشئ إرادة.

فلكي تترسـخ القيم في نفس المتعلم، يحتـاج إلـى أن يتردد ذكرهـا على مســامعه،

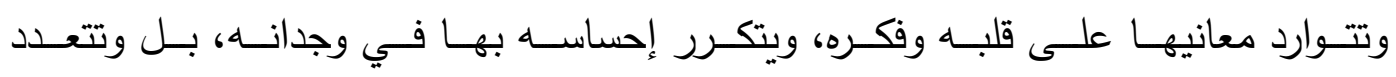

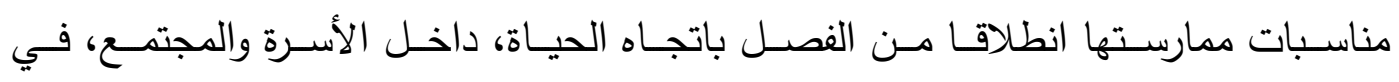

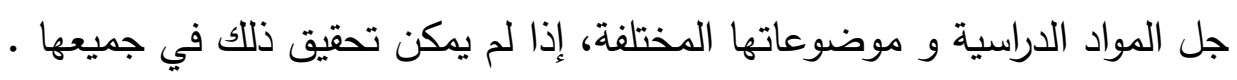
هـ الامتداد عبر مختلف المواد الدراسية.

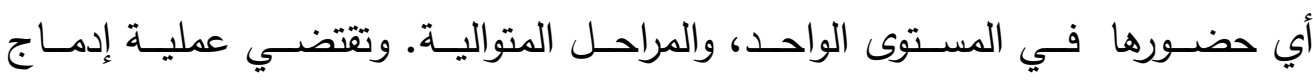

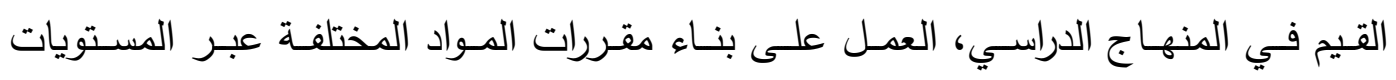

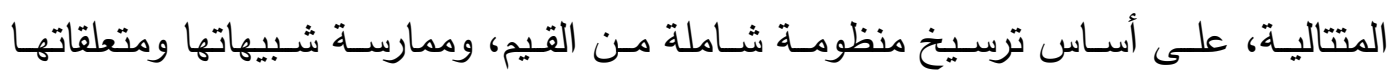

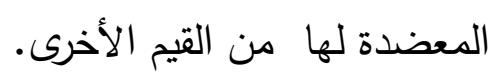


ففـي كـل مـادة تقـدم القـيم مـن خـلال منهجهـا الخـاص، والــي يوجـه للكشـف عـن

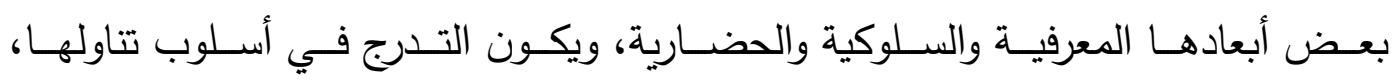
وعلى وفـق مـا يواكب نمـو المـتعلم العقلي والعـاطفي والجسـي، حتـى يتواصـل ترسـيخ

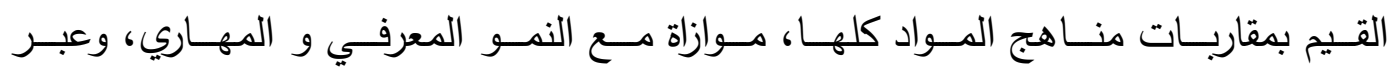
اكتساب مختلف الكفايات العامة والخاصة .

اذن نحـن اليـوم مطـالبين بوضـع عـدد مـن القـيم المطلوبـة فـي المنــاهج الدراسـية لإعـداد جيـل واعي مبتكر مـنظم فالإنسـان اليـوم يعيش في وسـط أمسواج متلاطمـة مـن

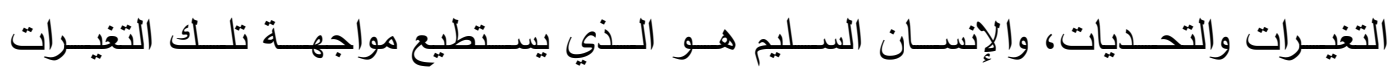

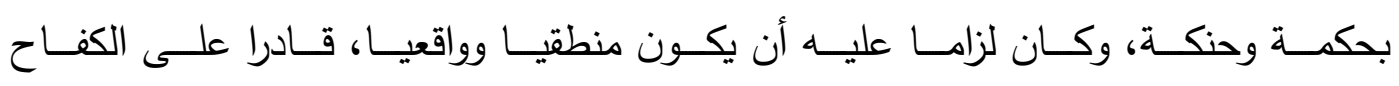
ومواجهـة الصـعاب، واقتحسام المخـاطر مـن أجـل إثبـات الـذات والـنفس، والرغبـة في أن وان

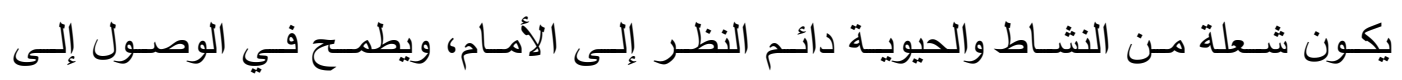
أهدافه بدقة وعناية ،متجاوزا الصعاب والمحن. فـالقيم هـي الوسـيلة التي تسـتمر بهـا عجلـة الحيـاة في تقـدم مسـتمر للفـرد وكذللك

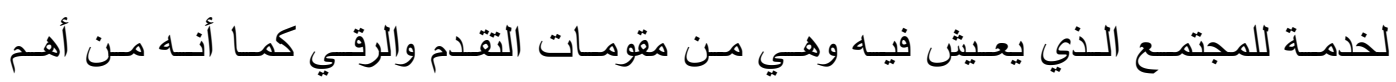

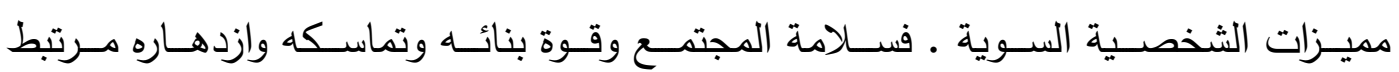
بـافراد مجتمعـه ل، فـالفرد هـو صـانع المسـتقبل وهـو المحسور والغايـة المنشـودة ،أمـا مـا حـول هـذا الفـرد مـن إنجـازات وتخطيطـات ليسـت أكثر مـن تقـدير لمـدى فعاليـة هـذا الفرد،ولهـذا فـالمجتمع الـواعي هـو الـذي يضــع نصـب عينيـهـ الفـرد كأسـاس للازدهــار والتقدم الاجتماعي قبل اهتماماته بالإنجازات المادية.

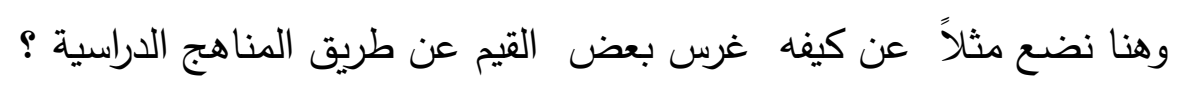

$$
\text { ا - التعاون : }
$$

يجـب أن تتضـمن بعـض الكتـب ولاسـيما فـي المرحلـة الابتدائيـة قيمـة التعـاون

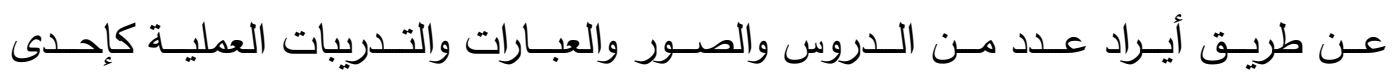
العـادات التـي اكتسـبها الفـرد وتكــون علـى صــور متعـددة : (( الأســرة ، المدرســة

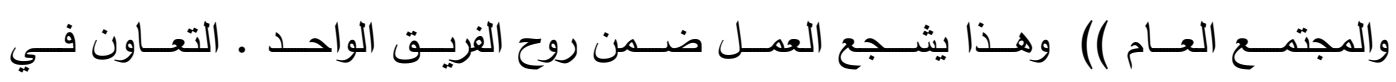

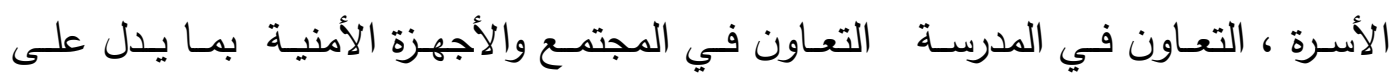

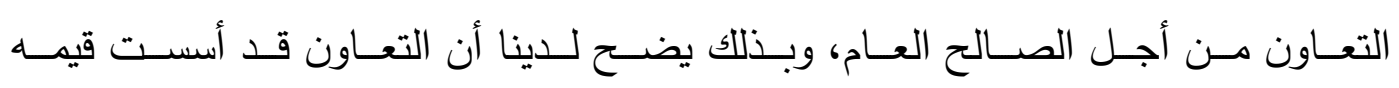
في الأسرة وامتد إلى المدرسة ثم إلى المجتمع • 


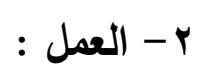

تضـمين عـدد مـن الــروس فـي المرحلــة الابتدائيـة والمتوسـطة تعمل على بـث

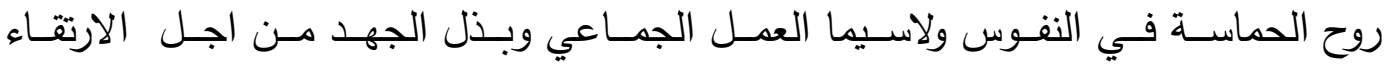
بالوطن إلى مصافي الأمم المتقدمة .

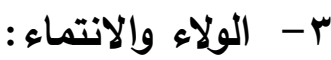

توجـهـ المنـاهج إلـى الـولاء والانتهــاء إلـى العائلــة الصـغيرة ، ثم تـزداد حلقـة الـولاء

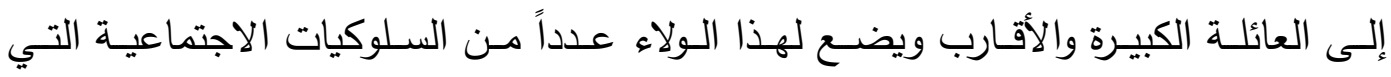

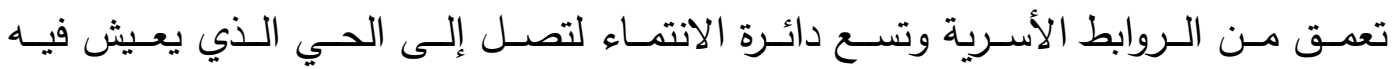

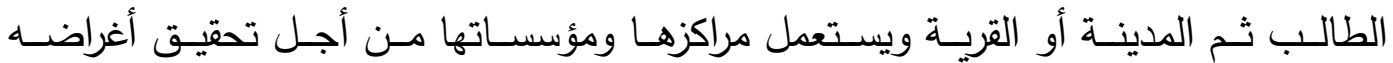

$$
\text { צ - الوحدة : احتياجاته }
$$

تعيق مشـاعر الوحدة في أبنائهـا ، وذلك لتقويـة كيانهـا داخليـاً ، ولحفظ وحدتها

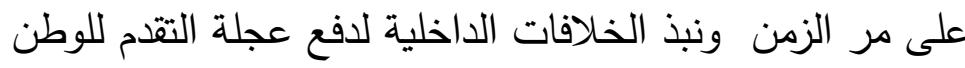
ه - زرع قيم التسامح ونبذ ثقافة الكراهية والعنف ورفض الآخر :

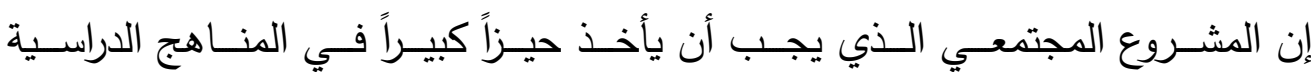

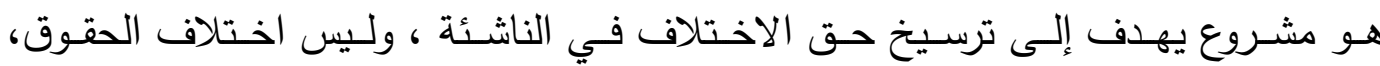
وهـذه النظـرة تتطلب تعلـم نسـبية قبـول بعض الثقافـات والمعتقـدات، فيمكن ممارسـتها

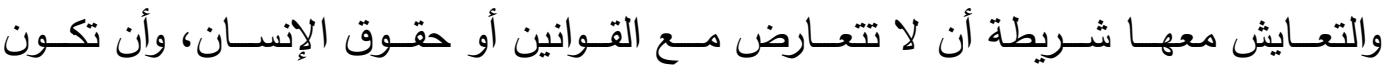

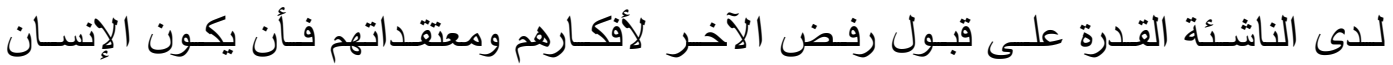

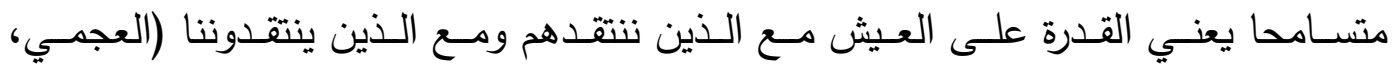
(r.

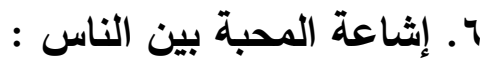

تضـمين قيم المحبـة يـدعوا إلى التـآخي وفي التآخي محبـة ، وأن وحدة الأهـاف

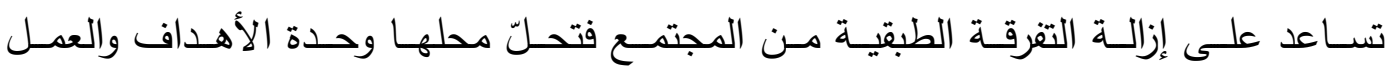

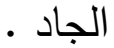

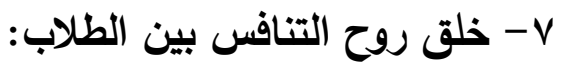

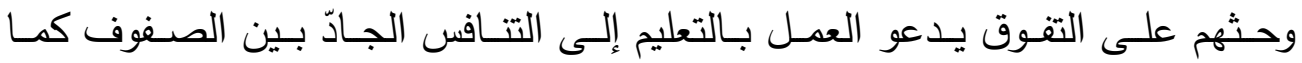

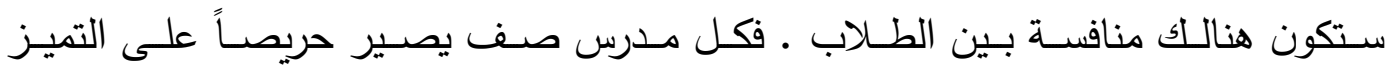

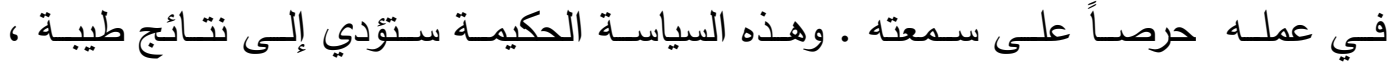
تحث الطلاب على حب التفوق. 
1- أيجاد روح التنافس بين المدارس:

عندما نقوم بخلق التـافس بـين المـارس سـتجتهد كل منهـا لتكون هـي صـاحبة

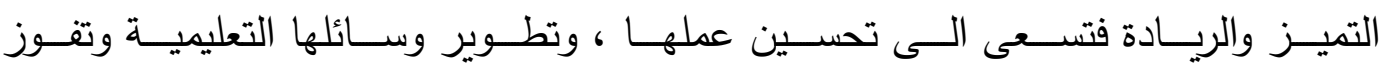

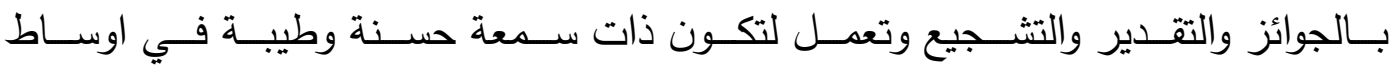

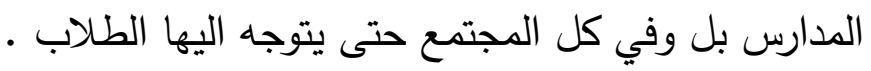
9- بث روح التفكير والاجتهاد في المجتمع :

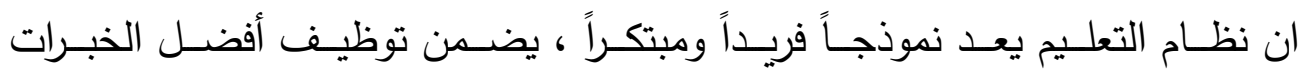

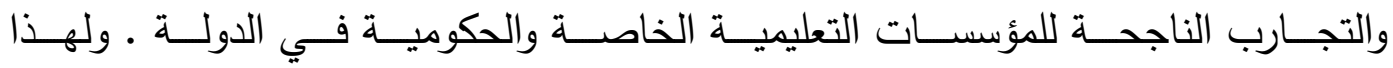

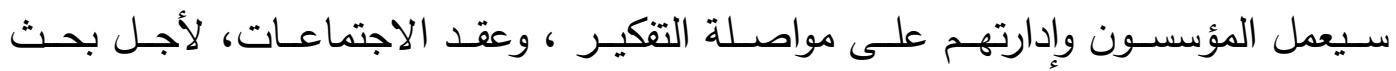

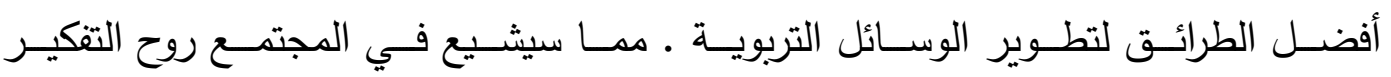
التربوي المفيد.

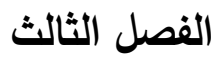
أولاً : الاستنتاجات

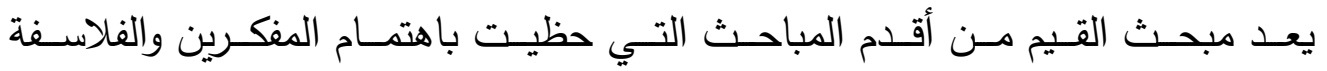

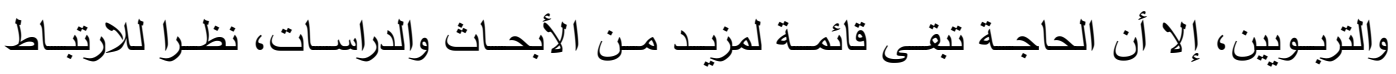

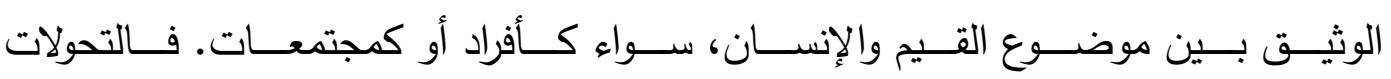

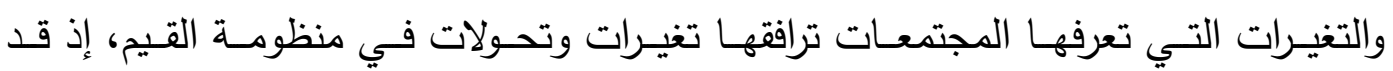

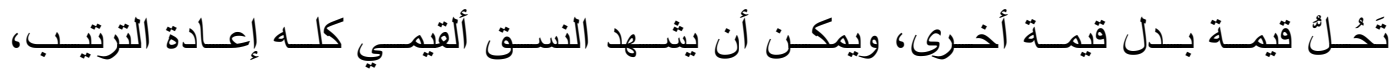

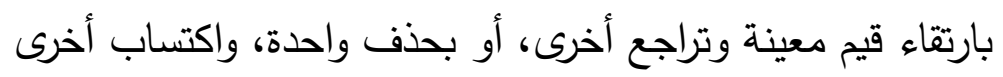

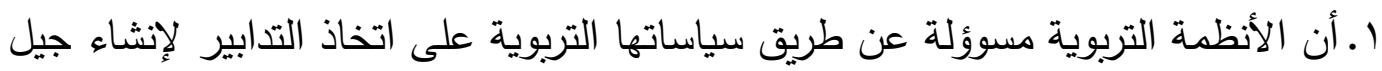

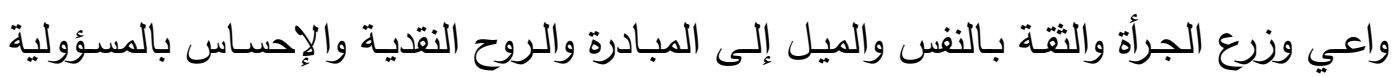
والقدرة على التكيف الاجتماعي مما يحمله ذلك من قيم التسامح وقبول الأخر .

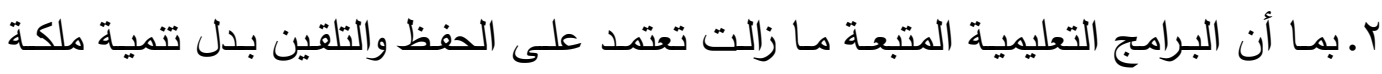

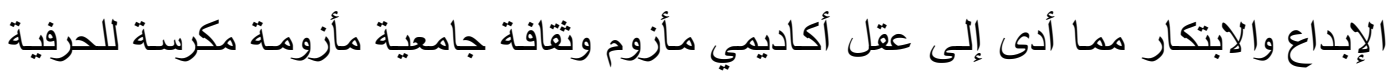

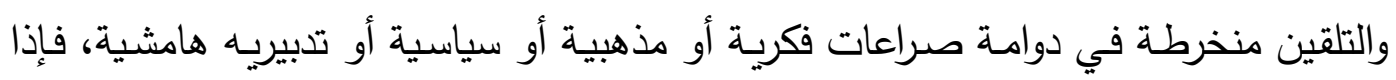
كان الحال كذلك فندن بحاجة إلى منظومة كاملة من القيم والأعراف من شأنها أن تساهم

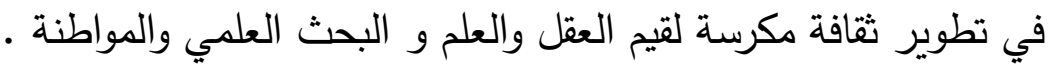

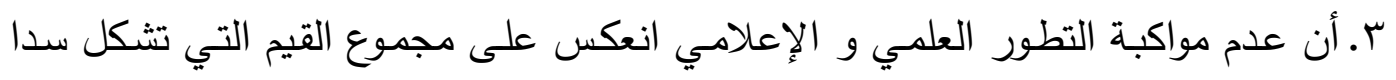

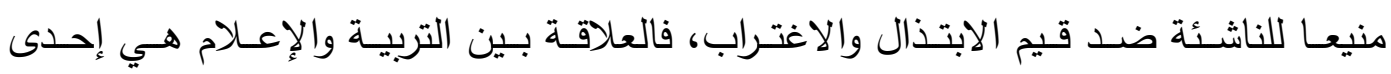

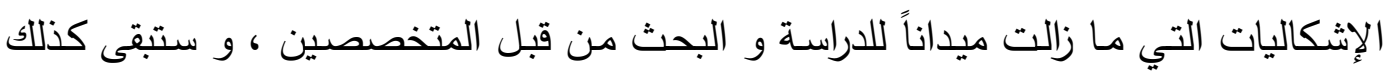


لطبيعة كل واحد منهما ، و لذا فلا بد من إعداد الدراسات و البحوث التي تجسّر العلاقة

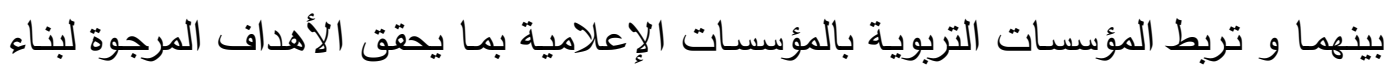

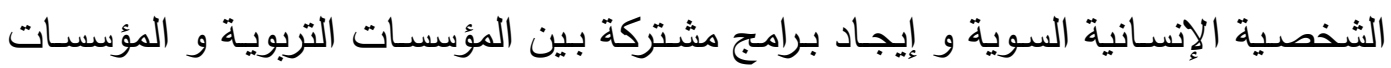

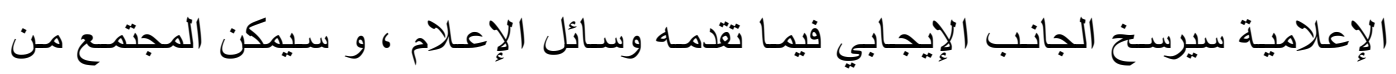
الافادة من هذه الوسائل لما يخدم منظومة قيمنا ومعتقداتتا.

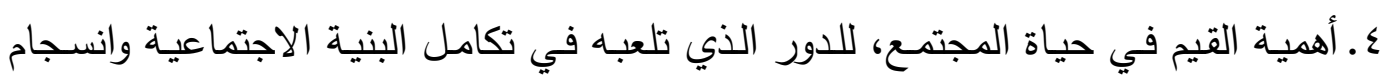

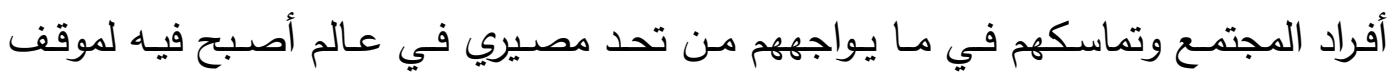
المجتمع الموحد أهمية كبيرة لبقائه وديمومته.

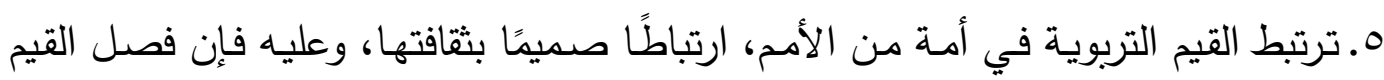

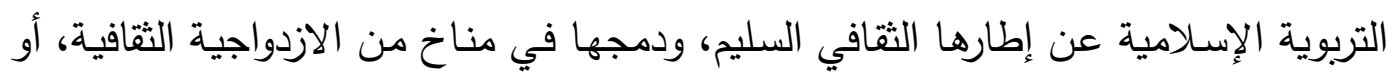

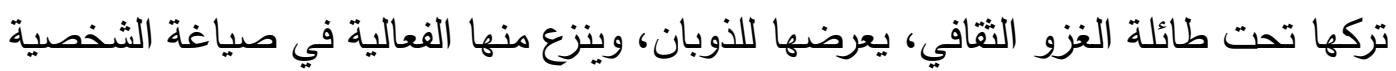
الإسلامية القوية وصنع الواقع الحضاري السليم.

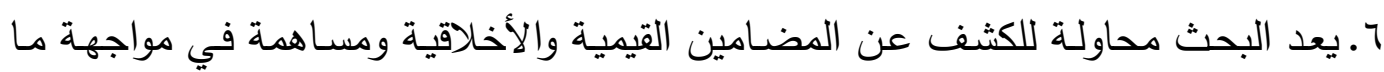

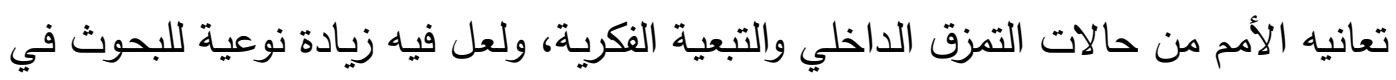

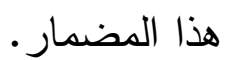
V. تبني مناهج حديثة في التعليم والتعلم المبنية على التفاعل الاجتماعي والذي تهدف إلى الى الإس

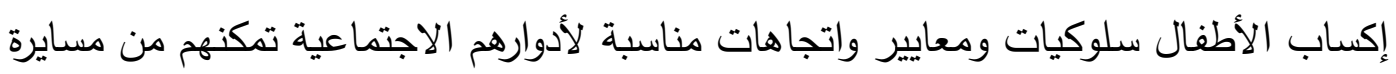

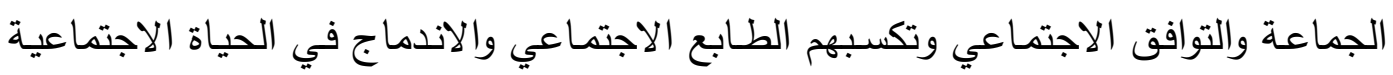
ما يجعلهم طموحين في مستقبل أفضل : مانكل ثانياً : توصيات: ا ـ وضع الأسس والمبادئ الموجهة لتعليم القيم والأساليب المعززة لها في المدارس في مختلف توفيات مراحلها . r. تحديد مجموعة من القيم التربوية التي لا توجد في المناهج لتضمينها المناهج التربوية الجديدة .

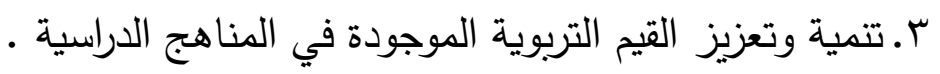

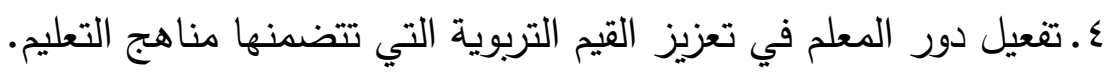

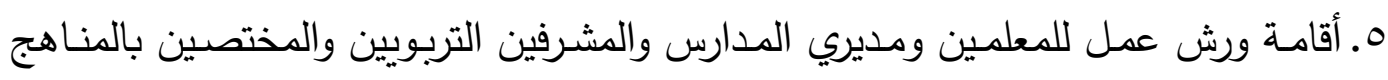
للتدرب والاستفادة من المواد التوعية وترجمتها إلى عمل يستفاد منه الطلبة . ثالثاً: المقترحات

ا ا. دراسة القيم في المناهج الدراسية للمراحل المختلفة

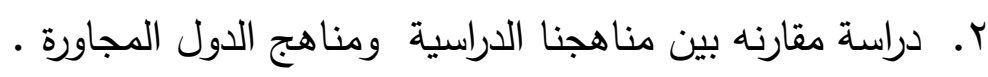




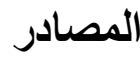

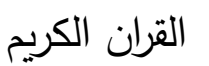

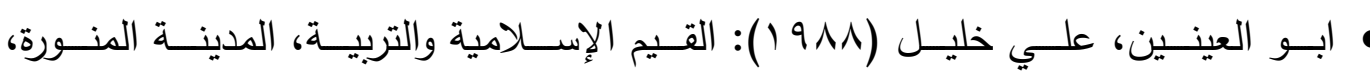
مكتبة ابراهيم الحلبي، سوريا

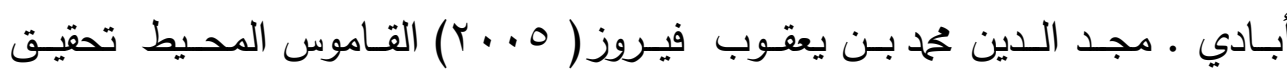

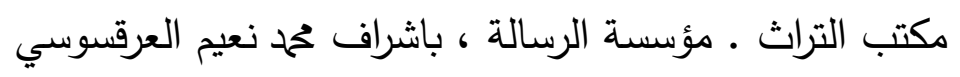

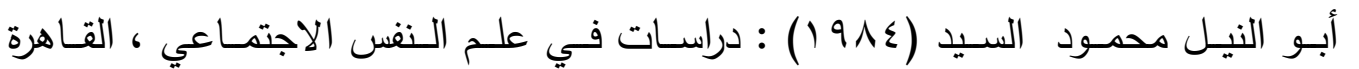

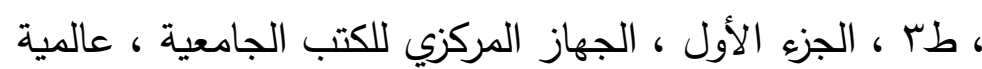

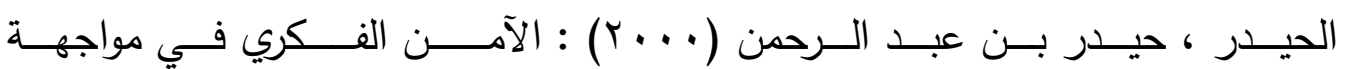

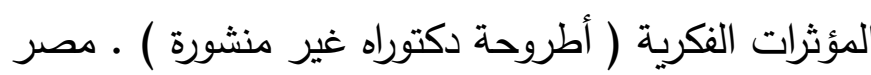

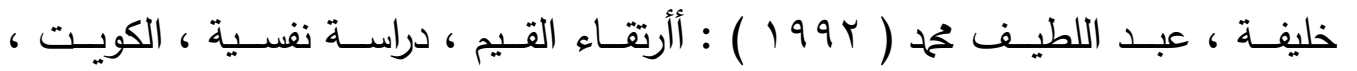
عالم الكتب ، المجلس الوطني للثقافة والفنون والادب

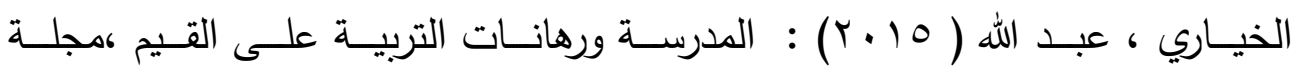

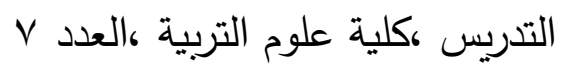

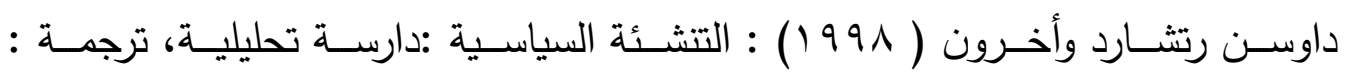
مصطفى عبدالله خشيم، محم المغربي، جامعة قاريونس، ليبيا

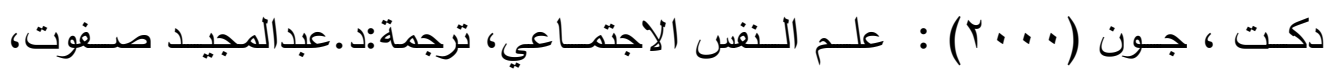
دار الفكر العربي القاهرة

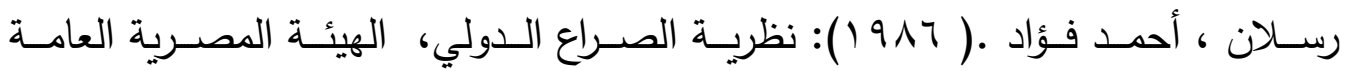

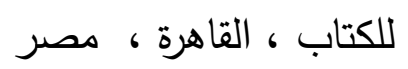

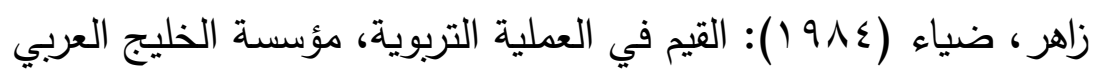

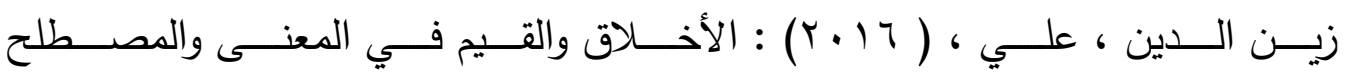

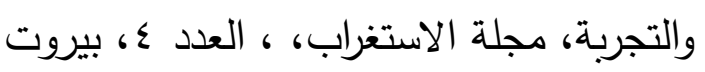

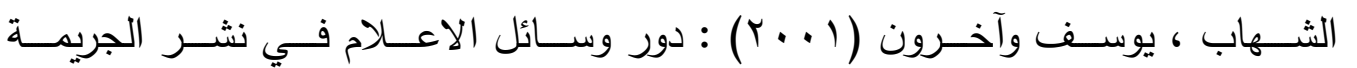

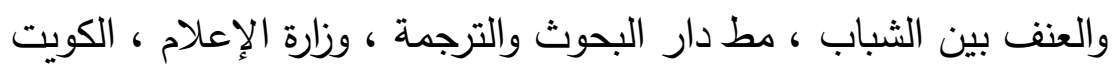

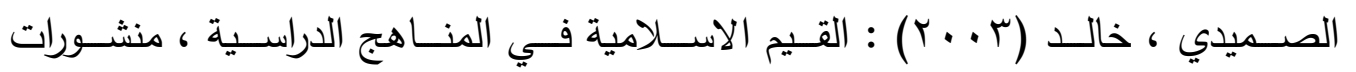

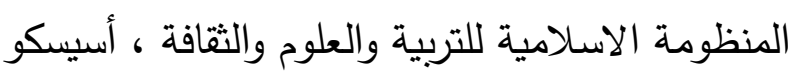

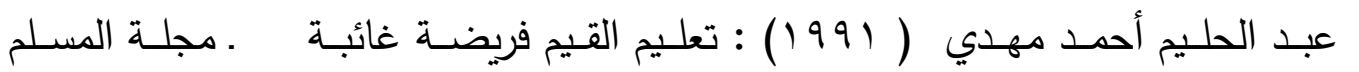
المعاصر 


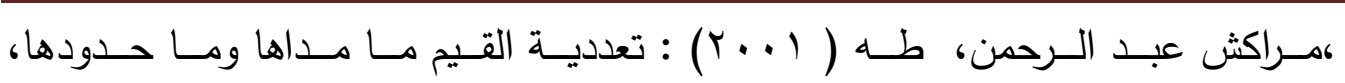
الدرس الجامعي الافتتاحي، جامعة القاضي عياض،

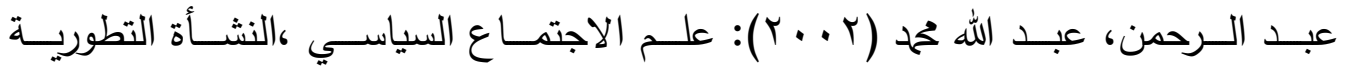

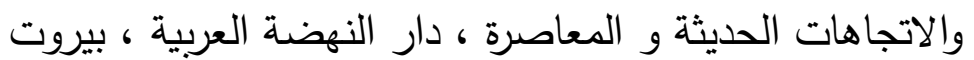

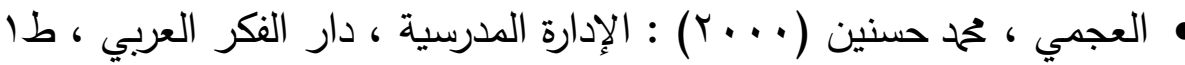

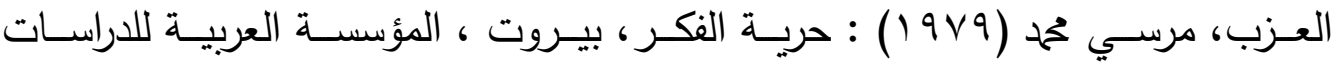
والنشر

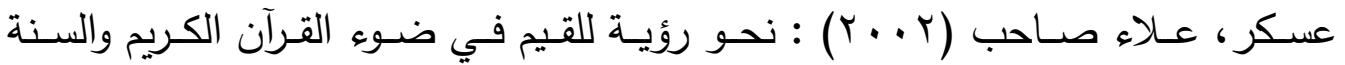
النبوية، أطروحة دكتوراه، كلية التربية(ابن رشد)

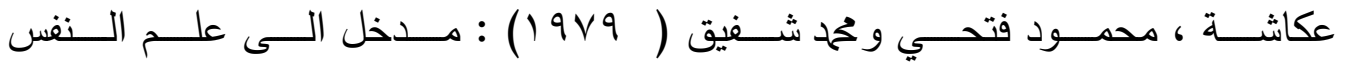
الاجتماعي ، القاهرة ، بل برنت للطباعة والنشر

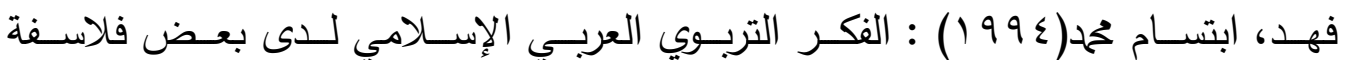

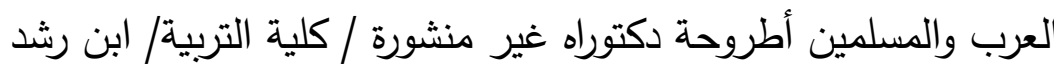

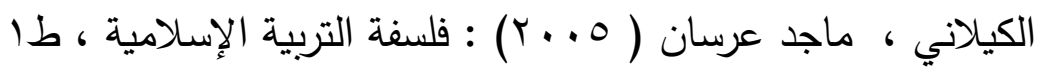

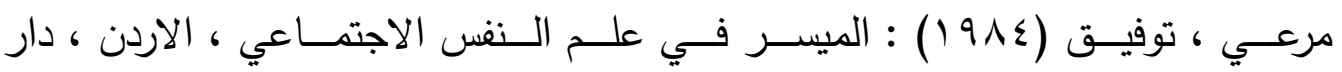

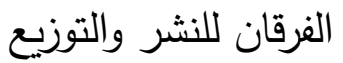

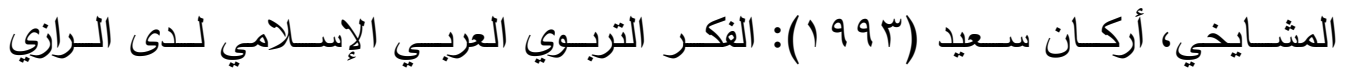

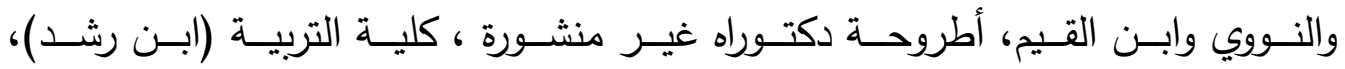

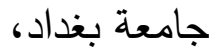

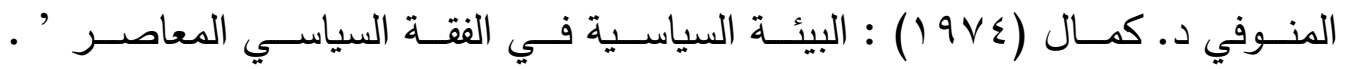
مطبعة النهضة

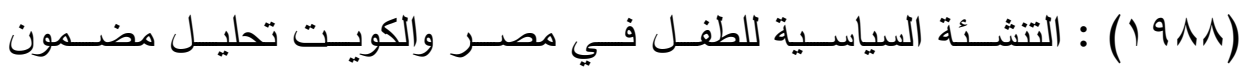

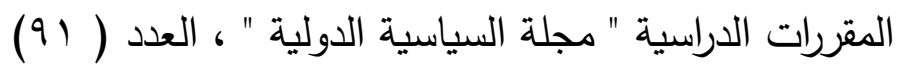

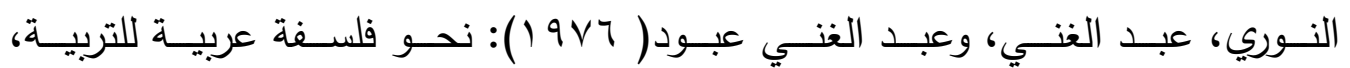
القاهرة، دار الفكر العربي، طا لطا

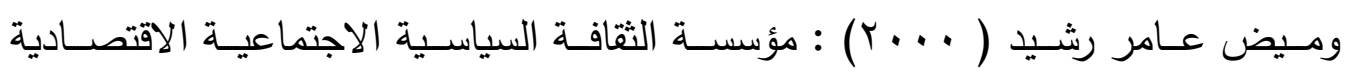
العسكرية " " مصطلحات ومفاهيم " ، دار المعارف، حمص، سوريا 


\title{
Values and their importance in the curriculum Numbers
}

\author{
Dr. Bashaer Mouloud Tawfiq \\ University of Baghdad / Center for Educational and Psychological \\ Research \\ Bashar mawloud@yahoo.com
}

\section{Summary of the research}

The objective of the current research was to identify the values and their importance in the curriculum. The limits of the search for information and literature that contribute to achieve its objectives were followed by the researcher to study the descriptive analytical method of its importance in the curriculum as the concept of values and their characteristics, , Values and family formation values and political formation, and educational mechanisms to integrate values in the curriculum, the research has reached some conclusions such as:

1-The importance of values in the life of society, the role it plays in the integration of social structure and the harmony of the members of society and their cohesion in the face of the challenge of fate in a world where the position of the unified community of great importance for its survival and sustainability.

.2-The educational values of a nation of nations are closely linked to their culture. Therefore, separating Islamic educational values from their proper cultural framework and integrating them into a climate of cultural duplication or leaving them under the threat of cultural invasion presents them with solubility. And made a sound civilized reality.

Proposals

1.Studying the values in the modern curriculum in different educational stages

2 .Comparison of modern curricula in neighboring countries.

Keywords: Values, Curriculum 